UNIVERSIDADE DE SÃO PAULO FACULDADE DE CIÊNCIAS FARMACÊUTICAS

PROGRAMA DE PÓS-GRADUAÇÃO EM TOXICOLOGIA E ANÁLISES TOXICOLÓGICAS

AVALIAÇÃO DOS EFEITOS TÓXICOS DA EXPOSIÇÃO PRÉ-NATAL AO FIPRONIL NA PROLE DE RATAS WISTAR

Mariana Sayuri Berto Udo

São Paulo 


$$
\text { UNIVERSIDADE DE SÃO PAULO }
$$

FACULDADE DE CIÊNCIAS FARMACÊUTICAS

PROGRAMA DE PÓS-GRADUAÇÃO EM TOXICOLOGIA E ANÁLISES TOXICOLÓGICAS

AVALIAÇÃO DOS EFEITOS TÓXICOS DA EXPOSIÇÃO PRÉ-NATAL AO FIPRONIL NA PROLE DE RATAS WISTAR

Mariana Sayuri Berto Udo

Dissertação para obtenção do grau de MESTRE

Orientador:

Profa. Dra. Helenice de Souza Spinosa

São Paulo 
Ficha Catalográfica

Elaborada pela Divisão de Biblioteca e

Documentação do Conjunto das Químicas da USP.

Udo, Mariana Sayuri Berto

U21a Avaliação dos efeitos tóxicos da exposição pré-natal ao fipronil na prole de ratas Wistar / Mariana Sayuri Berto Udo. -- São Paulo, 2012.

$143 \mathrm{p}$.

Dissertação (mestrado) - Faculdade de Ciências Farmacêuticas da Universidade de São Paulo. Departamento de Análises Clínicas e Toxicológicas.

Orientador: Spinosa, Helenice de Souza

1. Praguicidas: Toxicologia 2. Toxicologia reprodutiva I. T. II. Spinosa, Helenice de Souza, orientador. 
Mariana Sayuri Berto Udo

\title{
AVALIAÇÃO DOS EFEITOS TÓXICOS DA EXPOSIÇÃO PRÉ-NATAL AO FIPRONIL NA PROLE DE RATAS WISTAR
}

\author{
Comissão Julgadora \\ da
}

Dissertação para obtenção do grau de Mestre

Prof. Dra. Helenice de Souza Spinosa

Orientadora/ presidente

$1^{0}$ examinador

$2^{0}$ examinador

São Paulo, de de 2012. 


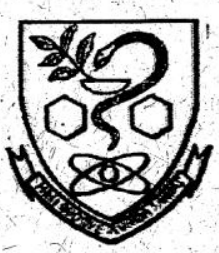

Ofício CEUAFCF/27/2010

IImo(a). Sr(a)

Mariana Sayuri Berto Udo

Orientador Profa. Dra. Helenice de Souza Spinosa

FBC

Prezado(a) Senhor(a),

A Comissão de Ética no Uso de Animais da FCF/USP, em reunião realizada em 12 de abril de 2010 , apreciou o projeto "Avaliação dos efeitos tóxicos da exposição ao Fipronil no período perinatal" (Protocolo CEUA $n^{\circ} 272$ ) apresentado por Vossa Senhoria, entretanto, em função do Decreto $n^{\circ}$ 6.899/09, o mesmo deverá ser apresentado à Comissāo de Ética no Uso de Animais da Instituiçāo onde o experimento será realizado.

Após a aprovação do projeto a cópia do respectivo certificado deverá ser encaminhada a esta Comissão para ciência.

Atenciosamente,

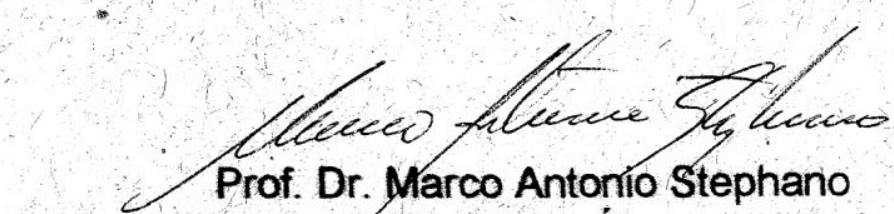

Coordenador da Comissão de Ética no Uso de Animais

CEUAFCFIUSP 


\section{Comissão de Ética no uso de animais}

\section{CERTIFICADO}

Certificamos que o Projeto intitulado "Avaliação dos efeitos tóxicos da exposição ao Fipronil no período perinatal", protocolado sob o n ${ }^{\circ} 1924 / 2010$, utilizando 50 (cinquenta) ratos, sob a responsabilidade da Profa. Dra. Helenice de Souza Spinosa, está de acordo com os princípios éticos de experimentação animal da "Comissão de Ética no uso de animais" da Faculdade de Medicina Veterinária e Zootecnia da Universidade de São Paulo e foi aprovado em reunião de 26/05/2010.

We certify that the Research "Evaluation of toxic effects of exposure to Fipronil the perinatal period", protocol number 1924/2010, utilizing 50 (fifty) rats, under the responsibility Profa. Dra. Helenice de Souza Spinosa, agree with Ethical Principles in Animal Research adopted by "Ethic Committee in the use of animals" of the School of Veterinary Medicine and Animal Science of University of São Paulo and was approved in the meeting of day 05/26/2010.

São Paulo, 10 de junho de 2010

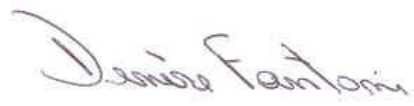

Profa. Dra. Denise Tabacchi Fantoni

Presidente 


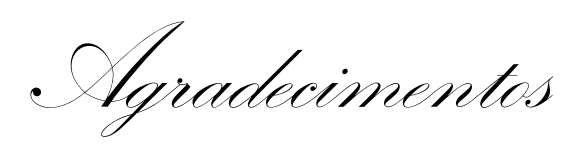

Agradeço à Deus e à Nossa Senhora, pela luz que ilumina meus caminhos, todos os dias de minha vida, e por tudo que eu tenho.

Agradeço aos meus pais, Sonia Maria Berto Udo e Paulino Noboru Udo, pela educação, que prezo muito; e aos meus irmãos, irmã, cunhado, cunhadas e sobrinhas, por fazerem parte da minha maravilhosa e unida família. Muito obrigada!

Agradeço ao meu namorado, Luiz Henrique Matuguma pela paciência, companheirismo e por todas as refeições maravilhosas cheias de amor. Obrigada por estar ao meu lado, mesmo nas noites extensas de análises de dados.

À família do meu namorado, muito obrigada por me apoiarem e acreditarem.

Agradeço muito à minha maravilhosa orientadora, Profa. Dra. Helinice de Souza Spinosa, pela oportunidade de realizar mais um sonho, e pela querida Profa. Dra. Maria Martha Bernardi. Obrigada pelo profissionalismo, amizade e confiança.

Aos meus amigos, Thaísa Sandini, Thiago Marinho, Beatriz Dorr, Aline Ameni, Izabel Mattos, Vanessa Anastácio, Jéssica Costa, Sheila Lima e Marcos Santana, obrigada pelas divertidíssimas tardes, pelo companheirismo, deliciosas risadas. Obrigada pelo privilégio de ser amiga de vocês.

Agradeço aos funcionários e técnicos do departamento de patologia da Faculdade de Medicina Veterinária e Zootecnia da USP: do biotério: Hidalina, Mauro, Nelsinho, Luciana e Claudia; do laboratório de farmacologia: Vagner, Herculano e Nicole; e da secretaria: Milena e Adriana, que de alguma forma colaboraram para o meu sucesso. 
Aos demais professores do departamento de patologia da Faculdade de Medicina Veterinária e Zootecnia da USP, obrigada pela convivência e por compartilhar do seu conhecimento.

À Universidade de São Paulo, à Faculdade de Ciências Farmacêuticas, obrigada por acolher-me como aluna de pós-graduação.

Aos funcionários, alunos e professores da Faculdade de Ciências Farmacêuticas por toda a ajuda.

À CAPES por conceder a bolsa de mestrado, e

À todos que diretamente, ou indiretamente, participaram dessa etapa de minha vida, MUITO OBRIGADA. 


\section{Resumo}

UDO, M. S. B. Avaliação dos efeitos tóxicos da exposição pré-natal ao fipronil na prole de ratas Wistar. 2012. 143f. Dissertação (Mestrado) - Faculdade de Ciências Farmacêuticas, Universidade de São Paulo, São Paulo. 2012.

O fipronil, um inseticida e acaricida de amplo espectro de ação, atua como bloqueador dos canais de cloreto acoplados aos receptores GABA (GABA-Cls) e aos receptores glutamatérgicos (GluCls), estes últimos são alvo inseto-específico não presente nos vertebrados. 0 fipronil é utilizado na agricultura, medicina veterinária e saúde publica no combate a vetores de doenças. Comercialmente conhecido pelas marcas Frontline ${ }^{\circledR}$ (uso veterinário) e Regent 800 WG ${ }^{\circledR}$ (uso agrícola), esse inseticida, além de atuar sobre sistema nervoso central, atua, ainda, em organismos não-alvo como desregulador endócrino, podendo causar prejuízos nos sistemas reprodutor, nervoso e imunológico, por gerações. Assim, o presente estudo buscou investigar os efeitos da exposição pré-natal ao fipronil na geração F1 de ratas Wistar. Quarenta ratas virgens, Wistar, adultas (a partir de 90 dias de vida), foram acasaladas e separadas em quatro grupos: três experimentais, que receberam: 0,1, 1,0 e 10,0 mg/Kg de peso de fipronil; e o grupo controle, que recebeu água ( $1 \mathrm{~mL} / \mathrm{Kg}$ de peso), via gavagem, do $6^{\circ}$ ao $20^{\circ}$ dia de gestação ( $\mathrm{n}=10$ animais por grupo). 0 estudo foi então dividido em três partes: 1) estudos sobre a toxicidade materna e o comportamento maternal dessas ratas no 5으 dia pós-nascimento (DPN5); 2) avaliação do desenvolvimento físico e reflexológico da geração F1, desde o dia de seu nascimento (DPN0) até o DPN35; e 3) avaliações comportamentais e de necropsia dos filhotes na idade adulta. 0 tratamento pré-natal com fipronil causou leve toxicidade materna na maior dose, apenas na segunda semana de gestação, caracterizada pela redução do consumo de ração $(\mathrm{p}<0,01)$, porém, essa redução não causou prejuízos no desempenho reprodutivo dessas ratas quando comparadas ao grupo controle. Além disso, o tratamento do fipronil mostrou leve melhoria do comportamento maternal, onde as ratas que receberam as doses de 1,0 e $10,0 \mathrm{mg} / \mathrm{Kg}$ apresentaram aumento do tempo de lambedura em seus filhotes $(\mathrm{p}<0,05)$, enquanto a maior dose agrupou toda a ninhada mais rapidamente $(p<0,05)$ quando comparadas ao grupo controle. $\mathrm{Na}$ infância, não foram observadas alterações significantes nos parâmetros do desenvolvimento físicos da prole, porém os filhotes que 
estiveram expostos à menor dose durante o período gestacional, apresentaram retardo para o desenvolvimento do reflexo de geotaxia negativa, tanto machos $(\mathrm{p}<0,01)$, quanto fêmeas $(\mathrm{p}<0,05)$. A análise do desenvolvimento motor desses filhotes, constatou alterações nos perfis da atividade geral em campo aberto, observados por sete dias consecutivos, nos grupos de 0,1 e $1,0 \mathrm{mg} / \mathrm{Kg}$, tanto na prole feminina, quanto na prole masculina. $\mathrm{Na}$ idade adulta, as proles de ratas tratadas com fipronil, tanto masculina, quanto feminina, apresentaram alterações comportamentais, indicando aumento de ansiedade e alterações no tempo de interação social. A prole masculina apresentou ainda, alteração na motivação sexual sem prejudicar a eficiência copulatória e a prole feminina apresentou alterações no ciclo estral, sem prejudicar o desempenho copulatório, ambos na menor dose de exposição pré-natal. Apesar das alterações comportamentais, a necropsia não mostrou alterações anatômicas nos órgãos desses animais. Assim, esses resultados sugerem que a exposição ao fipronil na gestação causou alterações na geração $\mathrm{F} 1$, sendo proposto o envolvimento do sistema endócrino regulado pelo sistema GABAérgico.

Palavras-chave: Fipronil, toxicologia do desenvolvimento, GABA, desregulador endócrino. 
UDO, M. S. B. Evaluation of toxic effects on Wistar rats offspring due to Fipronil prenatal exposition. 2012. 143f. Master assessment - Pharmaceutical Sciences Faculty, University of São Paulo, São Paulo. 2012.

Fipronil, a broad spectrum action insecticide and acaricide, acts blocking GABAregulated chloride channels and Glutamate-gated chloride channels, which is a specific insect - target not present on vertebrates. It is used in crops, veterinarian medicine and public health against disease vectors. Commercially known as Frontline ${ }^{\circledR}$ (vet) and Regent $800 \mathrm{WG}^{\circledR}$ (crops), it acts on the central nervous system and on non-target organisms as an endocrine disruptor causing impairment on reproductive, nervous and immunological system, through generations. Thus, this study investigated effects of prenatal exposition to fipronil in Wistar rats offspring. Forty adult Wistar rats (90 days old) were matted and separated into four groups: three experimental, that received 0.1 , 1.0 , and $10.0 \mathrm{mg} / \mathrm{Kg}$ (bw) of fipronil; and the control group, that received water (1 $\mathrm{mL} / \mathrm{Kg} \mathrm{bw}$ ), through gavage from the $6^{\text {th }}$ to $20^{\text {th }}$ pregnancy day $(\mathrm{n}=10$ animals per group). The study was divided into three sections: 1) maternal toxicity and maternal behavior evaluations; 2) physical end reflexological development of F1 generation, since day of birth until the $35^{\text {th }}$ day of life; and 3) behavior and necropsy evaluation of the adult offspring. The fipronil prenatal treatment caused slight maternal toxicity in the highest dose on the second pregnancy week, by the reduction of food intake $(p<0,01)$, although, these reduction did not caused reproductive performance impairment, compared to the control group. Furthermore, the fipronil treatment showed slight increase of maternal behavior in rats treated with 1.0 and $10.0 \mathrm{mg} / \mathrm{Kg}$. Both groups showed increased pup-grooming time $(p<0,05)$, and the highest dose, grouped theirs pups earlier than the control group $(\mathrm{p}<0,05)$. No alterations were observed in the offspring physical development, however, the lowest dose exposed offspring showed delay on geotaxis reflex development, in both male $(p<0,01)$ and female offspring $(\mathrm{p}<0,05)$. The motor development assessment, of the 0.1 and $1.0 \mathrm{mg} / \mathrm{Kg}$ dose offspring, showed variation on motor activity profile on the open field arena, observed for seven consecutive days. In the adulthood, the treated offspring, male and female, showed behavior changes denoting anxiety increase and social behavior alterations. 
Furthermore, in the lower dose, male offspring showed decrease on sexual motivation without interfering on copulatory efficiency and the female offspring showed estrus cycle deregulation without interfering on lordosis performance. Despite behavior alterations, there were no anatomic alterations in these animals' organs. Therefore, these results suggest that the prenatal exposition to fipronil caused alterations on F1 generation, being proposed involvement of the endocrine system controlled by GABAeregciystem.

Key-words: Fipronil, development toxicity, GABA, endocrine disruptor. 


\section{LISTA DE FIGURAS}

Figura 1: Estrutura molecular do fipronil 24

Figura 2: Vias de degradação do fipronil no ambiente 28

Figura 3: Possível mecanismo de reação de fotólise do fipronil em solução aquosa

Figura 4: Vias de degradação do fipronil no organismo dos mamíferos

Figura 5: Fotografias de espermatozóides obtidos de swab vaginal de ratas

Figura 6: Fotografia de uma administração via oral, por gavagem, em rata

Figura 7: Fotografia de um filhote de rata identificado com nanquim em uma das patas do membro pélvico

Figura 8: Fotografias dos parâmetros do desenvolvimento físico observados

Figura 9: Fotografias dos parâmetros do desenvolvimento reflexológico observados

Figura 10: Fotografia da arena de campo aberto

Figura 11: Fotografia do aparato de labirinto em cruz elevado, mostrando suas divisões

Figura 12: Fotografia mostrando o aparato de trave elevada e esquema ilustrativo

Figura 13: Diferentes fases do ciclo estral de ratas

Figura 14: Consumo semanal de ração das ratas prenhes expostas ou não (controle) ao fipronil, do $6^{\circ}$ dia ao $20^{\circ}$ dia de gestação

Figura 15: Parâmetros do comportamento maternal de ratas expostas ou não (controle) ao fipronil, do $6^{\circ}$ ao $20^{\circ}$ dia de gestação

Figura 16: Peso corporal (em gramas) da prole feminina de ratas expostas ou não (controle) ao fipronil, do $6^{\circ}$ ao $20^{\circ}$ dia de gestação

Figura 17: Dia de andar adulto da prole feminina de ratas expostas ou não (controle) ao fipronil, do $6^{\circ}$ ao $20^{\circ}$ dia de gestação

Figura 18: Geotaxia negativa (em dias) da prole feminina e masculina de ratas expostas ou não (controle) ao fipronil, do $6^{\circ}$ ao $20^{\circ}$ dia de gestação

Figura 19: Perfil locomotor observado em campo aberto, do DPN15 ao DPN21, da prole masculina e feminina, de ratas expostas ou não (controle) ao fipronil, do $6^{\circ}$ ao $20^{\circ}$ dia de gestação 
Figura 20: Perfil dos parâmetros da atividade geral em campo aberto, por 7 dias consecutivos, da prole masculina de ratas expostas ou não (controle) ao fipronil, do $6^{\circ}$ ao $20^{\circ}$ dia de gestação

Figura 21: Perfil dos parâmetros da atividade geral em campo aberto, por 7 dias consecutivos, da prole feminina de ratas expostas ou não (controle) ao fipronil, do $6^{\circ}$ ao $20^{\circ}$ dia de gestação

Figura 22: Parâmetros avaliados no teste de campo aberto, por 5 min, na prole adulta de ratas expostas ou não (controle) ao fipronil, do $6^{\circ}$ ao $20^{\circ}$ dia de gestação

Figura 23: Parâmetros do comportamento em labirinto em cruz elevado da prole de ratas expostas ou não (controle) ao fipronil, do $6^{\circ}$ ao $20^{\circ}$ dia de gestação

Figura 24: Tempo de interação social entre os animais cujas mães estiveram expostas, ou não (controle), ao fipronil do $6^{\circ}$ ao $20^{\circ}$ dia de gestação

Figura 25: Incidência de aparecimento das diferentes fases do ciclo estral, em 21 dias consecutivos de observação, de fêmeas cujas mães estiveram expostas ou não (controle) ao fipronil, do $6^{\circ}$ ao $20^{\circ}$ dia de gestação

Figura 26: Escores de erros atribuídos aos passos do membro pélvico da prole feminina, cujas mães estiveram expostas ou não (controle) ao fipronil, do $6^{\circ}$ ao $20^{\circ}$ dia de gestação

Figura 27: Coeficiente de lordose das ratas, cujas mães estiveram expostas ou não (controle) ao fipronil, do $6^{\circ}$ ao $20^{\circ}$ dia de gestação

Figura 28: Escores de erros atribuídos aos passos do membro pélvico da prole masculina, cujas mães estiveram expostas ou não (controle) ao fipronil, do $6^{\circ}$ ao $20^{\circ}$ dia de gestação 


\section{LISTA DE TABELAS}

Tabela 1 - Concentração de fipronil (em ppm) encontrado nos diversos tecidos de ratas, após a administração, por via oral, de 4 e $40 \mathrm{mg} / \mathrm{Kg}$ de fipronil

Tabela 2 - Escores para avaliação da qualidade do novo ninho construído, quando da avaliação do comportamento maternal

Tabela 3 - Parâmetros do desenvolvimento físico e as datas do início da observação de cada parâmetro

Tabela 4 - Escores atribuídos ao tempo de imobilidade do animal em campo aberto

Tabela 5 - Escores atribuídos ao caminhar do animal na porção central da trave elevada

Tabela 6 - Consumo semanal de água de ratas prenhes expostas ou não (controle) ao fipronil, do $6^{\circ}$ dia ao $20^{\circ}$ dia de gestação

Tabela 7 - Peso gestacional semanal das ratas expostas ou não (controle) ao fipronil, do $6^{\circ}$ ao $20^{\circ}$ dia de gestação

Tabela 8 - Parâmetros do desempenho reprodutivo de ratas exposta ou não (controle) ao fipronil durante a gestação

Tabela 9 - Parâmetros do comportamento maternal das ratas expostas ou não (controle) ao fipronil, do $6^{\circ}$ ao $20^{\circ}$ dia de gestação

Tabela 10 - Peso corporal (em gramas) dos filhotes (macho e fêmea) de ratas expostas ou não (controle) ao fipronil, do $6^{\circ}$ ao $20^{\circ}$ dia de gestação

Tabela 11 - Parâmetros do desenvolvimento físico da prole de ratas expostas ou não (controle) a diferentes doses de fipronil, do $6^{\circ}$ ao $20^{\circ}$ dia de gestação

Tabela 12 - Parâmetros do desenvolvimento reflexológico (em dias) da prole de ratas expostas a diferentes doses de fipronil, do $6^{\circ}$ ao $20^{\circ}$ dia de gestação

Tabela 13 - Frequência de locomoção no campo aberto, do DPN15 ao DPN21, da prole de ratas expostas ou não (controle) ao fipronil, do $6^{\circ}$ ao $20^{\circ}$ dia de gestação

Tabela 14 - Frequência de levantar no campo aberto, do DPN15 ao DPN21, da prole de ratas expostas ou não (controle) ao fipronil, do $6^{\circ}$ ao $20^{\circ}$ dia de gestação 
Tabela 15 - Frequência de auto-limpeza no campo aberto, do DPN15 ao

DPN21, da prole de ratas expostas ou não (controle) ao fipronil, do $6^{\circ}$ ao $20^{\circ}$ dia de gestação

Tabela 16 - Tempo de imobilidade em campo aberto, do DPN15 ao DPN21, da prole de ratas expostas ou não (controle) ao fipronil, do $6^{\circ}$ ao $20^{\circ}$ dia de gestação

Tabela 17 - Parâmetros da atividade geral em campo aberto, na prole adulta de ratas expostas ou não (controle) ao fipronil, do $6^{\circ}$ ao $20^{\circ}$ dia de gestação

Tabela 18 - Parâmetros de avaliação do comportamento em labirinto em cruz elevado da prole, na idade adulta, de ratas expostas ou não (controle) ao fipronil, do $6^{\circ}$ ao $20^{\circ}$ dia de gestação

Tabela 19 - Incidência de aparecimento das diferentes fases estrais, em 21 dias consecutivos, de fêmeas cujas mães estiveram expostas ou não (controle) ao fipronil, do $6^{\circ}$ ao $20^{\circ}$ dia de gestação

Tabela 20 - Parâmetros do comportamento sexual masculino da prole de ratas expostas ou não (controle) ao fipronil, do $6^{\circ}$ ao $20^{\circ}$ dia de gestação

Tabela 21 - Peso real ( $\mathrm{g}$ ) e relativo (\%) dos órgãos de fêmeas, cujas mães estiveram expostas ou não (controle) ao fipronil, do $6^{\circ}$ ao $20^{\circ}$ dia de gestação

Tabela 22 - Peso real ( $\mathrm{g}$ ) e relativo (\%) dos órgãos de machos, cujas mães estiveram expostas ou não (controle) ao fipronil, do $6^{\circ}$ ao $20^{\circ}$ dia de gestação 


\section{SUMÁRIO}

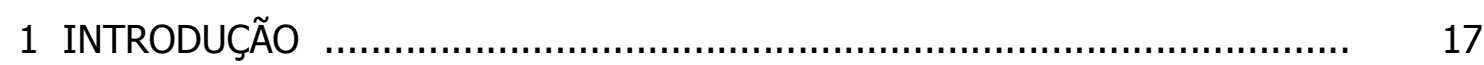

2 REVISÃO DA LITERATURA ............................................................... 22

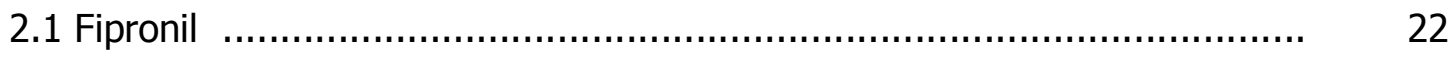

2.2 Toxicologia do Desenvolvimento ……………….............................. 39

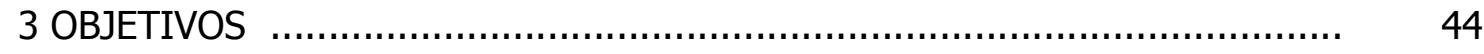

4 MATERIAL E MÉTODOS ............................................................ 46

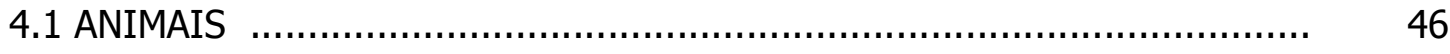

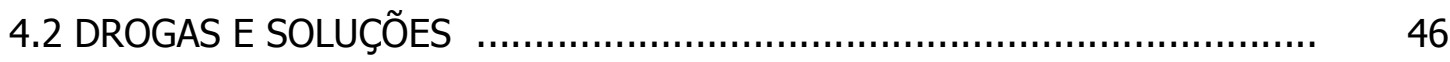

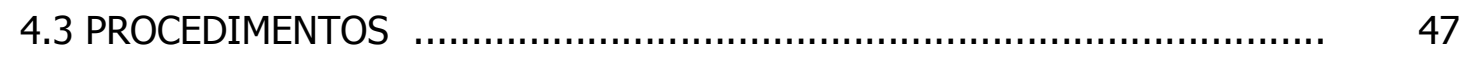

4.3.1 Acasalamento e Diagnóstico de prenhez ……................................. 47

4.3.2 Administração do fipronil .......................................................... $\quad 48$

4.3.3 Comportamento maternal .......................................................... 49

4.3.4 Desenvolvimento físico e reflexológico ............................................ 50

4.3.5 Campo Aberto …………………………………................... 54

4.3.6 Labirinto em Cruz Elevado ....................................................... $\quad 56$

4.3.7 Interação Social .................................................................... 57

4.3.8 Coordenação Motora em Trave Elevada .......................................... 58

4.3.9 Avaliação do ciclo estral ..............................................................

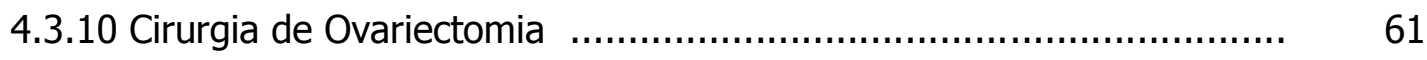

4.3.11 Comportamento sexual .......................................................... 62

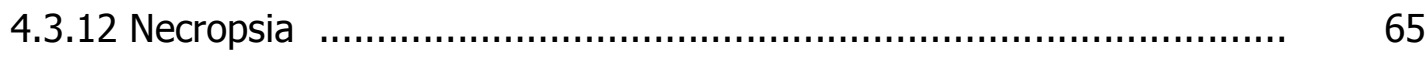

4.3.13 Análise Estatística ............................................................. 66

5 DELINEAMENTO EXPERIMENTAL E RESULTADOS ……........................... 68

5.1 Parte 1

Experimento 5.1.1: Efeito da administração de fipronil, durante a gestação, nos parâmetros reprodutivos de ratas Wistar 
Experimento 5.1.2: Efeito da administração de fipronil, durante a gestação, no comportamento maternal de ratas Wistar

\subsection{Parte 2}

Experimento 5.2.1: Efeito da administração de fipronil, durante a gestação, no desenvolvimento físico e reflexológico da prole de ratos

Experimento 5.2.2: Efeito da administração de fipronil, durante a gestação, na atividade motora geral em campo aberto

\subsection{Parte 3}

Experimento 5.3.1: Efeitos da administração de fipronil, durante a gestação, na resposta comportamental em campo aberto, labirinto em cruz elevado e interação social da prole na idade adulta

Experimento 5.3.2: Efeito da administração de fipronil, durante a gestação, nos parâmetros sexuais da prole feminina

Experimento 5.3.3: Efeito da administração de fipronil, durante a gestação, no comportamento sexual da prole masculina

Experimento 5.3.4: Efeito da administração de fipronil, durante a gestação, sobre as estruturas anatômicas da prole

6 DISCUSSÃO

7 CONCLUSSÕES 
1. Intradusão

"Você não pode voltar atrás e fazer um novo começo, mas pode começar agora e fazer um novo fim.”

(Chico Xavier) 
Muitas são as substâncias químicas conhecidas em todo o mundo, cerca de onze milhões, das quais três mil são produzidas em larga escala. As indústrias químicas estão em constante busca para a obtenção de novos compostos para serem usados com diferente finalidade, como, por exemplo, inseticidas, detergentes, repelentes, desinfetantes, fragrâncias, solventes, retardantes de chama entre outros. (SOLOMON; SCHETTLER, 2000; FONTELENE, 2010).

Anualmente, toneladas de substâncias sintéticas e naturais são lançadas no meio ambiente; várias delas propriedades estrogênicas ou de hormônios tireoidianos, sendo conhecidas como interferentes endócrinos ou desreguladores endócrinos; algumas são persistentes no meio ambiente, lipofílicas, bioacumulativas e tem baixa pressão de vapor, o que facilita sua dispersão e difusão no meio ambiente (ALVES, 2007; ROMANO; ROMANO; OLIVEIRA, 2009; FONTELENE, 2010; GUIMARÃES, 2010; PINTO E SILVA, 2011).

O termo desregulador endócrino (do inglês "endocrine disruptor") começou a ser empregado em 1991 para denominar os agentes ou substâncias químicas exógenas, presente no meio ambiente, capazes de interferir no funcionamento normal do sistema hormonal de organismos vivos ou de sua progenia (McLACHLAN, 2001; FONTELENE, 2010; SANTAMARTA, 2010).

O Programa Internacional de Segurança Química (PISQ), criado em 1980, que envolve a Organização Mundial de Saúde (OMS), o Programa das Nações Unidas para o Ambiente (PNUA) e a Organização Internacional do Trabalho (OIT), decidiu optar, em conjunto com peritos do Japão, dos Estados Unidos da América, do Canadá, da Organização de Cooperação e de Desenvolvimento Econômico (OCDE) e da União Européia, pela seguinte definição de desregulador endócrino: 
"é uma substância ou um composto exógeno que altera uma ou várias funções do sistema endócrino e, consequentemente, causa efeitos adversos sobre a saúde de um organismo intacto, na sua descendência, ou em (sub) populações, sendo caracterizado não pela sua natureza química, mas de acordo com os seus efeitos biológicos"

Os desreguladores endócrinos são capazes de mimetizar, bloquear ou modular a resposta endócrina por meio da interação com os receptores dos hormônios esteróides até mesmo em órgãos não reprodutivos como a glândula tireóide, o sistema cardiovascular e o ósseo (DASTON; COOK; KAVLOCK, 2003; BIANCO, 2010).

Os sistemas reprodutor, nervoso e imunológico são os principais alvos dos desreguladores endócrinos. Podem ser observadas anormalidades relacionadas a esses sistemas, como feminilização/desfeminilização, masculinização/ desmasculinização, infertilidade e declínio populacional, bem como adelgaçamento da casca do ovo, disfunções da glândula tireóide, anormalidades metabólicas, alterações no desenvolvimento, distúrbios comportamentais e doenças autoimunes. Há ainda a possibilidade de relação entre a exposição aos xenobióticos na vida uterina, durante a infância ou adolescência com o aumento dos casos de câncer de mama e a puberdade precoce (KOIFMAN; KOIFMAN; MEYER, 2002; SANTAMARTA, 2010).

Os desreguladores endócrinos podem ser agrupados em duas classes: substâncias sintéticas utilizadas na agricultura e seus subprodutos, e substâncias naturais derivada de plantas, como, por exemplo, os fitoendógenos (BIANCO, 2010). Seus efeitos podem ser agudos ou crônicos, dependendo do tempo de exposição, 
concentração no ambiente, modo de contato com o produto e tipo de degradação (AKINGBEMI et al., 2004; ROMANO; ROMANO; OLIVEIRA, 2009).

Da mesma forma que muitas substâncias, o fipronil, (RS)-5-amino-1-(2,6dichloro-a, a,a-trifluoro-p-tolyl)-4-trifluoromethylsulfinylpyrazole-3-carbonitrile, é uma substância sintética relativamente recente no mercado e que é considerada um desregulador endócrino (SGP-CECBP, 2009). Ele foi descoberto em 1987 e introduzido no comércio em 1993 (GHISI, 2010).

O fipronil é um inseticida da família dos fenilpirazóis usado para o controle de pragas de solo e de folhas em uma variedade de culturas, bem como em formulações contra pulgas e carrapatos para animais domésticos (ANVISA, 2011; FAOUNDER, 2007).

CONNELLY (2001) ressalta que o fipronil possui vasta gama de ação e que seus múltiplos usos parecem dar-Ihe uma vantagem sobre outros inseticidas, sendo eficaz, em baixas taxas de aplicação, contra insetos resistentes aos piretróides, organofosforados e carbamatos.

Por ser mais específico aos receptores dos insetos do que aos dos mamíferos (ZHAO, 2003), o fipronil é muito utilizado na agricultura, em medicina veterinária e para o e controle de pragas urbanas (ZHAO, 2004). No entanto, é altamente tóxico para o meio ambiente e para organismos não-alvo como peixes e invertebrados aquáticos (COX, 2005). Além disso, já foi relatado alterações fisiológicas e comportamentais em abelhas expostas a doses sub-letais desse praguicida (FAOUNDER, 2007).

COX (2005) relatou que animais expostos ao fipronil apresentaram disfunções em hormônios tireoidianos, causando tumores benignos e malignos, e em hormônios 
sexuais, interfere no desenvolvimento sexual dos filhotes machos e aumenta o tempo de intervalo entre os períodos férteis em fêmeas, levando à infertilidade (OHI, 2003; COX, 2005).

O fipronil é um inseticida de segunda geração que atua bloqueando os canais de cloreto acoplados aos receptores do ácido gama-aminobutírico (GABA) (TINGLE, 2003; IKEDA, 2004; OHI, 2003; ZHAO, 2004, BOBÉ, 1998), interferindo na atividade do sistema nervoso central (SNC) e causando a morte do inseto por hiperexitação e paralisia (PEIXOTO; COELHO; BARBOSA et al, 2002, ZHAO, 2004). Já o lindano e os ciclodienos são inseticidas que fazem parte da primeira geração de bloqueadores dos canais de cloreto acoplado aos receptores GABA (ZHAO, 2000).

O GABA é o principal neurotransmissor inibitório do cérebro. Atua em muitas vias diferentes do SNC e praticamente todos os neurônios são sensíveis aos seus efeitos (RANG et al, 2004); por isso tem sido associado a eventos fisiológicos e fisiopatológicos que envolvem a função e/ou a disfunção cerebral (SILVA, 2008).

Considerando que a maioria dos trabalhos referentes aos possíveis efeitos nocivos do fipronil são realizados em estudos de exposição aguda e apenas alguns se referem às alterações reprodutivas ao longo das gerações, esse trabalho tem por objetivo avaliar as alterações no desenvolvimento físico e comportamental da prole de ratos expostos ao fipronil durante o período gestacional. 
QRevisão da literatura

“Aprender é a única coisa de que a mente nunca se cansa, nunca tem medo nem se arrende"

(Leonardo Da Vinci) 


\subsection{Fipronil}

Descoberto pela transnacional Rhône-Poulenc Agro em 1987, o fipronil foi introduzido no mercado apena em 1993 (TINGLE et al., 2000) e foi registrado em maio de 1996 pela Agência de Proteção Ambiental dos Estados Unidos (United States Environmental Protection Agency - USEPA) como um praguicida de segunda geração e classificação toxicológica de tipo II (USEPA, 1996; JACKSON et al., 2009; MARTINS, 2009; GHISI, 2010).

O fipronil, derivado quimicamente da família do fenilpirazol ou fiproles, é um inseticida e acaricida de amplo espectro de ação usado para o controle de muitos insetos de solo e de folha em plantações de algodão, arroz, batata, cana-de-açúcar, e de outras culturas (GUPA, 2007; MARTINS, 2009), bem como em formulações contra pulgas e carrapatos de animais domésticos (OHI, 2004; FAOUDER, 2007), e em domissanitário empregados em ações de higiene pública, contra formigas e baratas (ZHAO, 2005; MARTHINS, 2009; GHISI, 2010; ANVISA, 2011). O fipronil é ainda efetivo, em baixa taxa de aplicação, contra insetos resistentes a outros agentes como os piretróides, os organofosforados e os carbamatos (ZHAO, 2000; GUNASEKARA et al., 2007).

GUNASEKARA et al. (2007) ressalta que uma aplicação de fipronil em grãos de arroz à $12,5 \mathrm{~g}$ ingrediente ativo (i.a.)/ha é mais eficiente do que malation à $300 \mathrm{~g}$ (i.a.)/ha e propicia proteção contra insetos chironomides por 9-14 dias depois do aparecimento nos grãos de arroz.

O fipronil tem apresentado alto grau de satisfação na clínica veterinária, com indicação para filhotes a partir de oito semanas de idade e em cadelas 
gestantes e lactantes, para o controle de pulgas e para o tratamento de sarna sarcóptica, especialmente em filhotes (PEIXOTO; COELHO; BARBOSA, 2002).

\section{Aspectos físico-químicos}

Com peso molecular de 437,2 g/mol, o fipronil (figura 1), (RS)-5-amino-1(2,6-dichloro-a,a,a-trifluoro-p-tolyl)-4-trifluoromethylsulfinylpyrazole-3-

carbonitrile (nomenclatura da International Union of Pure and Applied Chemistry - IUPAC) possui de baixa a moderada solubilidade em água: 0,0019 $\mathrm{g} / \mathrm{L}$ em pH 5 ou 0,0024 g/L em pH 9 (JACKSON et al., 2011); tem como sinônimo químico o MB 46030 (FAO/WHO, 2001) e pode ser encontrado comercialmente com vários nomes: Icon $^{\circledR}$, Ascend $^{\circledR}$, Chipco $^{\circledR}$, Adonis ${ }^{\circledR}$, Regent $^{\circledR}$ (todos de uso agrícola), Topline ${ }^{\circledR}$ e Frontline ${ }^{\circledR}$ (de uso veterinário).

O grupamento $\mathrm{CF}_{3}$ do fipronil, na posição 4 (tri-flour-metil-sulfini-pirazol), confere maior lipossolubilidade a molécula (CABONI et al., 2003), o que facilita sua deposição em tecido adiposo (GUPTA, 2007) e contribui muito para a sua potência (HAINZL; COLE; CASIDA, 1998).

A formulação de fipronil é frequentemente apresentada como isca de insetos, spray e soluções para pets e animais de grande porte, e como produtos granulados para gramados no controle de grilos (USEPA, 2001), incluindo também líquidos, pós e grânulos que dispersam na água, microgrânulos, sólidos desprezíveis e emulsões aquosas (TINGLE et al., 2003). Sua densidade é maior do que da água, pode ser degradado por fotólise e hidrólise, em condições 
alcalinas; apresenta ainda degradação microbial dependendo das condições do solo (GUNASEKARA et al., 2007).

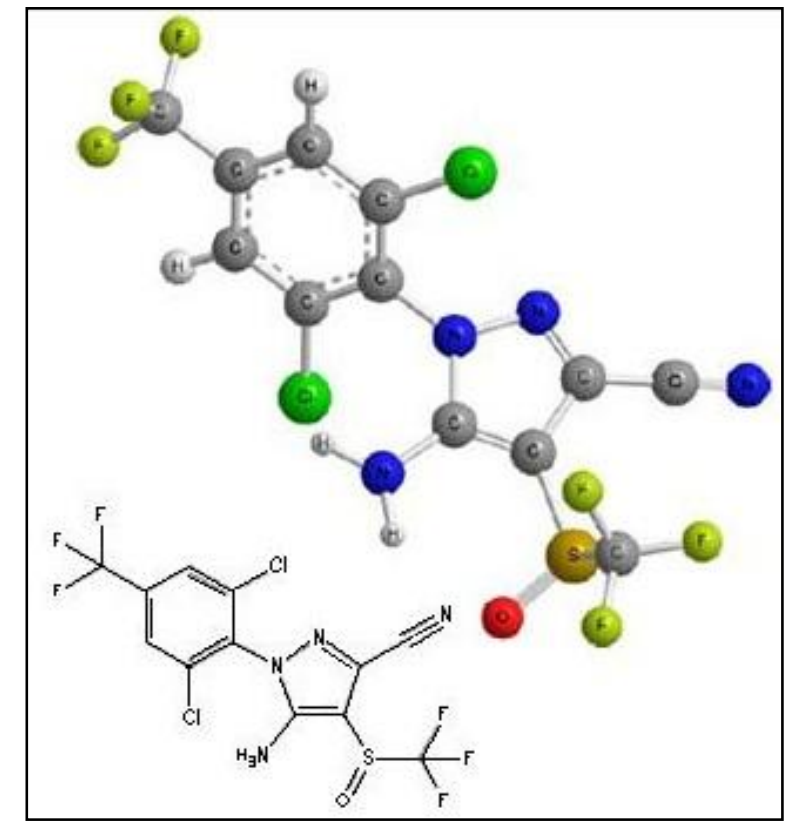

Figura 1: Estrutura molecular do fipronil (JACKSON et al., 2009)

\section{Mecanismo de ação}

O fipronil é um inseticida que interfere com os canais de cloreto acoplados aos receptores do ácido gama-aminobutirico (GABA), atuando como bloqueador não competitivo desses canais, impedindo o influxo dos íons cloreto e assim interferindo na transmissão dos impulsos nervosos entre células nervosas e musculares (RHÔNEPOULENC，1995; USEPA; 1996; CABONI, 2003; IKEDA, 2004; GUNASEKARA; TROUNG, 2007; NARASHI, 2007; ISLAM; LYNCH, 2012).

O GABA é o principal neurotransmissor inibitório do SNC, desempenhando um papel importante na regulação da excitabilidade neuronal. Nos vertebrados, - GABA atua em sinapses inibitórias através da ligação aos receptores 
específicos transmembranares em ambos os neurônios, pré- e pós-sináptico (RANG et al., 2004). Atualmente são conhecidas três classes de receptores GABAérgicos: $G_{A B A_{A}}$ e $G A B A_{c}$, que são receptores ionotrópicos, e $G A B A_{B}$, receptor metabotrópico; esse último é um receptor ligado a proteína G (CHEBIB et al., 2007).

Os receptores $G A B A_{A}$ dos mamíferos são glicoproteínas transmembranares heteroligoméricas compostas de cinco subunidades de sete famílias. Pelo menos uma subunidade $a$, umas $\beta$ e uma $y$ são necessárias para 0 funcionamento total dos receptores. In vitro, o fipronil se liga a um receptor homoligomérico $\beta 3$ de forma relativamente fraca e a um receptor nativo de insetos com alta afinidade, cerca de 100 vezes maior, quando comparados aos receptores de mamíferos (MOHAMED et al., 2004).

IKEDA e colaboradores (2004) demonstraram que o fipronil diminui a duração da abertura do canal de cloreto nos receptores GABAérgicos de Drosophila. Em receptores $\mathrm{GABA}_{A}$ de ratos, esse inseticida encurtou o tempo médio de abertura e prolongou o tempo fechado, manifestando diminuição na frequência de abertura do canal, desregulação no potencial de membrana das células nervosas, levando à hiperexcitação.

ZHAO (2000), em um estudo realizado com receptores $G_{A B A_{A}}$ de ratos, constatou que o fipronil bloqueou lentamente e reversivelmente as correntes induzidas por GABA e o efeito inibitório ocorreu tanto no receptor aberto quanto no receptor fechado. Entretanto, a ativação do receptor facilitou o bloqueio causado pelo inseticida. 
CABONI (2003) destacou que o motivo de o fipronil ser mais tóxico aos insetos do que aos mamíferos deve-se às diferenças encontradas entre os receptores GABAérgicos dos insetos e os receptores $\mathrm{GABA}_{\mathrm{A}}$ dos mamíferos, tanto em relação à estrutura molecular quanto à função farmacológica, pois os receptores GABAérgicos dos insetos, diferentemente dos mamíferos, não são bloqueados por bicuculina e não são potencializados por benzodiazepínicos ou barbitúricos (NARAHASHI, 2007).

Estudos recentes mostram ainda, que, além do bloqueio dos canais de GABA, esse inseticida possui ação inibitória dos canais de cloro nos receptores de glutamato (GluCls), unicamente nos invertebrados (ZHAO, 2004, JANSSEN et al., 2007; NARAHASHI et al., 2009).

O fipronil também pode atuar nos canais de cloreto dos receptores de glicina (Gli-R). Os receptores $\mathrm{GABA}_{\mathrm{A}}$ e os Gli-Rs pertencem, ambos, a família dos receptores pentaméricos Cys-loop, acoplados a canais iônicos, e o fipronil inibe ambos com a mesma potência (ISLAM; LYNCH, 2012). Além disso, mais recentemente, verificou-se que os receptores GABAérgicos dos insetos podem ser mais ou menos sensíveis à ação do fipronil dependendo da existência dos processos de fosforilação e desfosforilação de proteínas quinases C (PKC) (MURILLO et al., 2011).

\section{Aspectos ambientais}

Por possuir pressão de vapor relativamente baixa, o fipronil não volatiliza e só é encontrado no ar se for utilizado na forma de spray. No solo, tem baixa 
mobilidade, o que resulta em baixo potencial de contaminação, além de ter tendência de dissipar-se longitudinalmente, facilitando a sua degradação por microorganismos (USEPA, 2001).

Devido a sua ampla utilização no controle de insetos em culturas e sementes, além da aplicação na água de irrigação para culturas de arroz (ANVISA, 2011), o fipronil, e seus derivados, são mais facilmente encontrados em solo e água.

Este inseticida se degrada rapidamente por redução, hidrólise, oxidação e fotólise para formar cinco metabólitos principais: 1) fipronil-sulfida (M\&B 45950), produto de redução no solo; 2) fipronil-amida (RPA 200766), produto de hidrólise em água e solo; 3) fipronil-sulfona (M\&B 46136), produto da oxidação em solo; 4) fipronil-desulfinil (M\&B 46513), resultado de fotólise; e 5) ácido fipronil-sulfônico (RPA 104615) (BOBÉ et al., 1998; RAVETON et al., 2007; GUNASEKARA et al., 2007; IPCS/INCHEM, 1997) (Figura 2). 


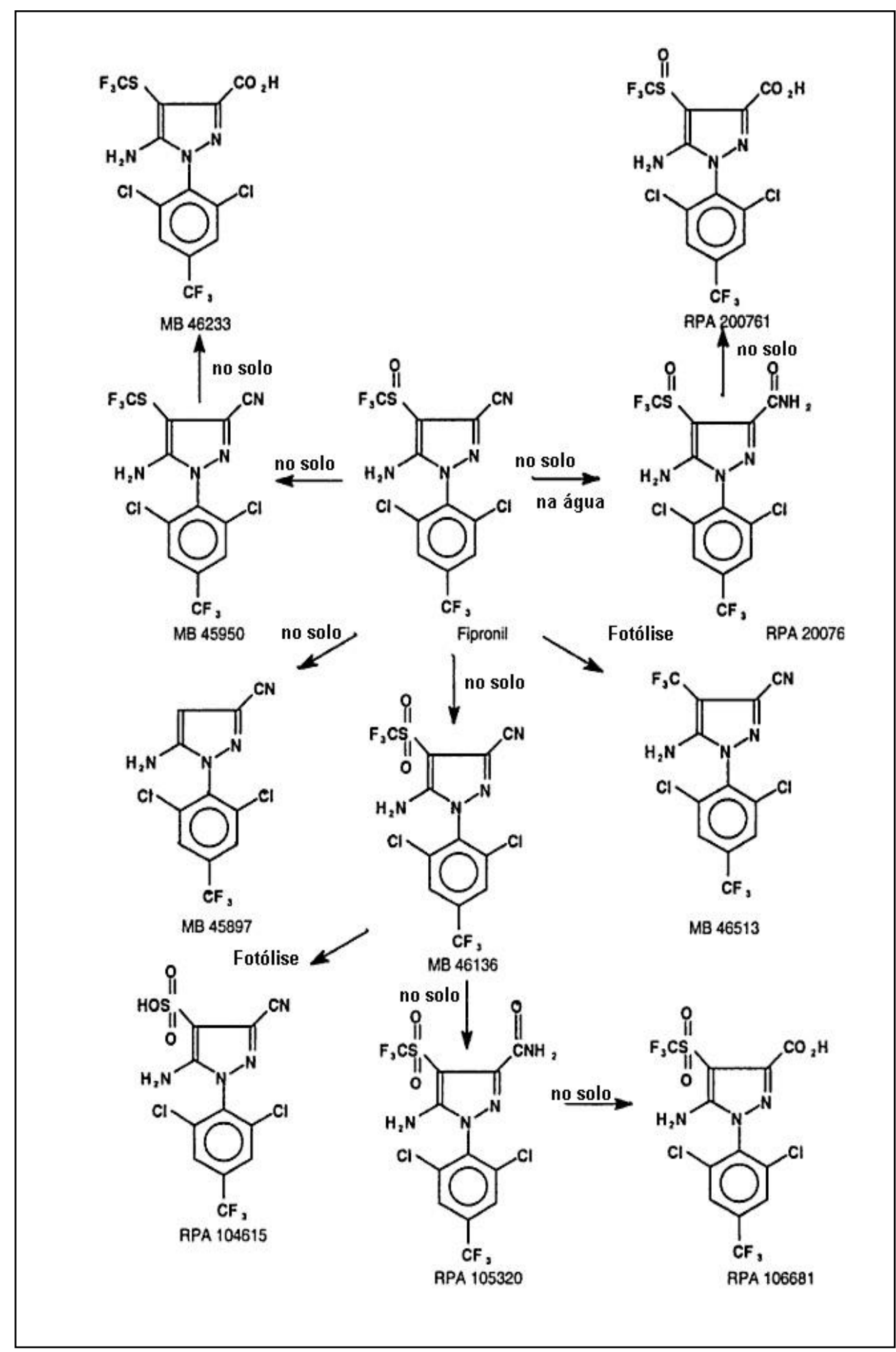

Figura 2: Vias de degradação do fipronil no ambiente (Adaptado de FAO/WHO, 2001) 


\section{Degradação em áqua}

Em soluções aquosas, quando não há incidência de luz, o fipronil permanece estável por muito tempo (meia vida de cerca de 1390 dias), desde que a solução seja ácida ou neutra ( $\mathrm{pH} 5,5$ ou 7,0) e esteja em temperatura ambiente $\left(22^{\circ} \pm 2^{\circ} \mathrm{C}\right)$; porém, em soluções alcalinas ( $\left.\mathrm{pH} 9-12\right)$, a degradação ocorre mais rapidamente, conforme o pH aumenta. Em pH 12, a degradação é 300 vezes mais rápida do que em pH 9 e a hidrólise, por si só, gera apenas um único produto: fipronil - amida (BOBÉ et al., 1998; USEPA, 2001; MARTINS, 2009).

Ainda em soluções aquosas, quando estas são expostas à luz, o fipronil sofre degradação por hidrólise e por fotólise; além disso, a reação de hidrólise fica mais rápida e os produtos gerados são dois: fipronil-desulfinil e o derivado ácido do fipronil-sulfona (BOBÉ et al., 1998; GUNASEKARA et al., 2007) (Figura 3). 


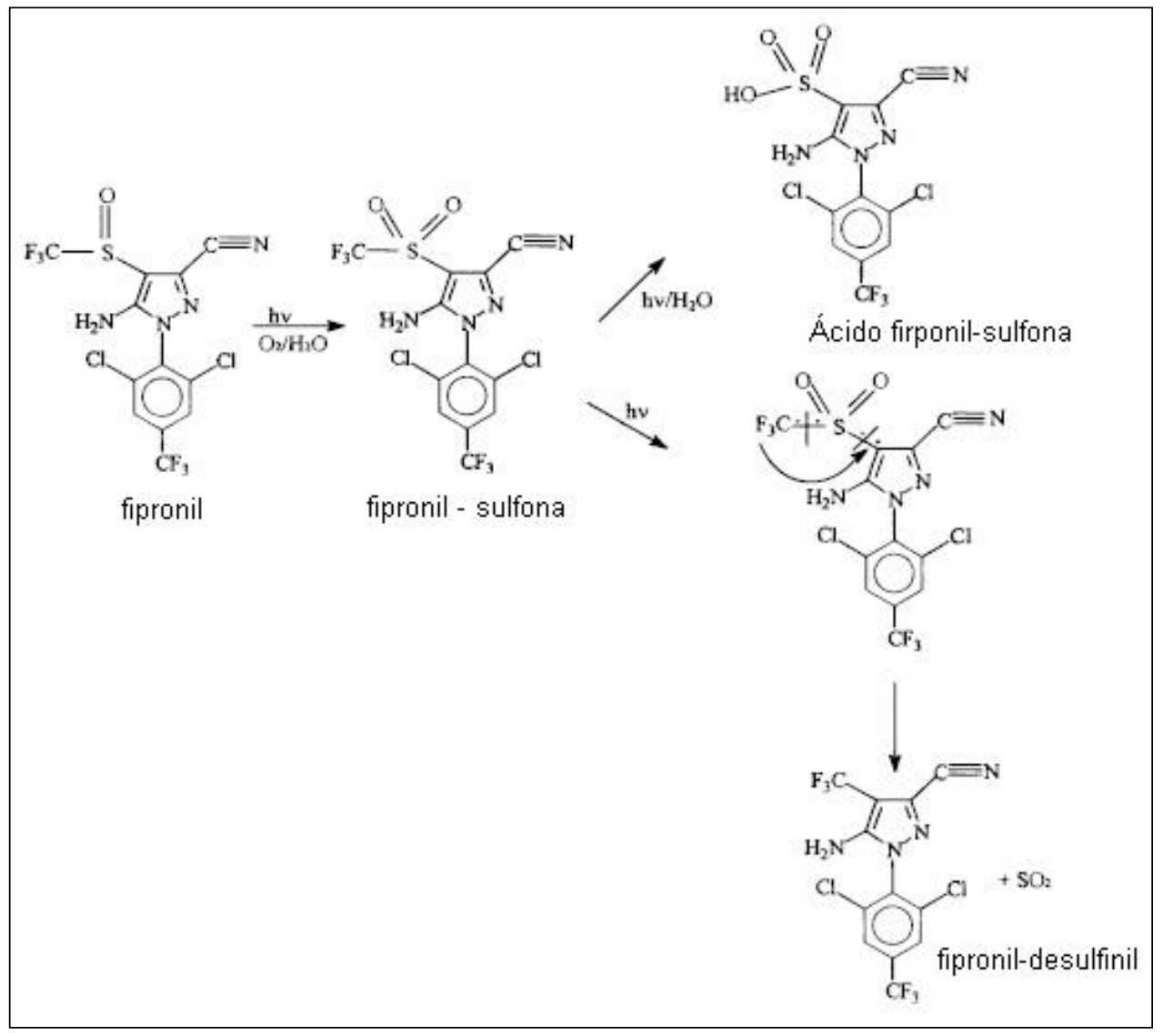

Figura 3: Possível mecanismo de reação de fotólise do fipronil em solução aquosa (Adaptado de BOBÉ et al., 1998)

\section{Degradação em solo}

O fipronil no solo, em situações reais, está sujeito à degradação por fotólise, principal via de degradação ambiental desse praguicida, e à degradação por microorganismo; assim, o tempo de meia vida dessa substância irá variar dependendo das condições do solo (MASUTTI e MERMUT, 2007; GUNASEKARA et al., 2007).

A degradação não ocorre na ausência da luz, BOBÉ et al. (1998) observaram que mais de $90 \%$ do fipronil aplicado em solo e mantido fora do 
alcance da luz, permaneceu inalterado por mais de 96 horas. Porém, sob a incidência de luz, a degradação pode ocorrer em diferentes velocidades dependendo das condições do solo e em todos os casos, é possível detectar a presença de apenas um composto de degradação: o fipronil-desulfinil.

\section{Degradação biótica em solo}

A degradação microbial do fipronil em solo não estéril e franco-argiloso tem meia vida $\left(\mathrm{t}_{1 / 2}\right)$ de aproximadamente 10 dias à $25^{\circ} \mathrm{C}$ e 9 dias à $35^{\circ} \mathrm{C}$. Essa degradação é três vezes mais longa (aproximadamente 33 dias) se o solo for estéril. O maior tempo já relatado foi de 342 dias em solo argiloso; em solo franco-argiloso arenoso o t $1 / 2$ é de 126 dias (USEPA, 1996).

A dissipação em solo anaeróbico se mostrou mais curta em campos de arroz da Califórnia; em água, o $t_{1 / 2}$ variou entre 0,5 a 5 dias enquanto que em solo foi de 2-22 dias (GUNASEKARA; TROUNG, 2007).

Além do fator microbial, a umidade é muito importante para degradação do fipronil. De fato, $0 t_{1 / 2}$ do fipronil foi de 68-198 dias dependendo da umidade do solo. Solos com umidade superior a $50 \%$ apresentam falta de aeração e, consequentemente, menos microorganismos, apresentando mais fipronil-sulfida como produto de degradação. Por outro lado, solos com boa aeração e menos que $50 \%$ de umidade, apresentam mais fipronil-sulfona por causa da ação degradadora de microorganismos aeróbicos (ZHU et al., 2004). 


\section{Mecanismos gerais de toxicidade}

O fipronil é uma molécula extremamente ativa e um potente desregulador do SNC, tanto em insetos quanto em mamíferos. Sua toxicidade é atribuída ao descontrole da atividade do SNC por bloquear os canais de cloreto acoplado aos receptores GABAérgicos (ZHAO, 2005), aos receptores de glicina (STHER et al., 2006) e receptores de glutamato (JANSSEN et al., 2007), além de atingir os organismos de maneira direta ou indiretamente. Diretamente, o fipronil pode atuar nos insetos, organismos aquáticos, aves e mamíferos (GUNASEKARA, 2007). Quando se menciona a ação indireta, se refere aos efeitos em organismos não alvos e ações não esperadas, como, por exemplo, o impacto no aumento da mortalidade de besouros (importantes no controle biológico de outras pragas na agricultura), mudanças nos padrões alimentares de garças (GUNASEKARA et al., 2007) e mudanças na aprendizagem e memória, e conseqüentemente no comportamento, em abelhas produtoras de mel (HASSANI, 2009). Ainda, FAOUNDER e colaboradores (2007) mostraram que traços do resíduo de fipronil (fipronil-sulfona, que apresenta a mesma atividade que o próprio fipronil) também puderam ser encontrados em leite de vacas leiteiras alimentadas com sementes tratadas.

\section{$\underline{\text { Insetos }}$}

O fipronil é um potente desregulador do SNC dos insetos, causando hiperatividade incontrolada do sistema e subseqüente morte do inseto. ZHAO e 
colaboradores (2004) ressaltaram que o fipronil também pode atuar inibindo os receptores de glutamato nos insetos, justificando a sua alta seletividade.

A atividade biológica do fipronil contra Diabrotica spp em cultura de milho é bem alta $\left(D_{50}=0,33 \mathrm{ng} / \mathrm{mg}\right)$. Além disso, ele também é altamente efetivo contra larvas de mosquitos Aedes aegypti, com $\mathrm{CL}_{50}=24,8 \mathrm{nM}$ (aproximadamente 11,7 $\mu \mathrm{g} / \mathrm{L}$ em 24h) e 15,1 nM (aproximadamente 7,14 $\mu \mathrm{g} / \mathrm{L}$ em 48h). Os produtos de degradação do fipronil são igualmente tóxicos: a $\mathrm{CL}_{50}$ de fipronil-sulfida e fipronil-sulfona é aproximadamente 8,8 nM (3,79 $\mu \mathrm{g} / \mathrm{L})$ (TINGLE et al., 2000; GUNASEKARA, 2007).

ZHAO e colaboradores (2005) observaram que a $\mathrm{DL}_{50}$ para moscas (housefly) foi de $0,13 \mathrm{mg} / \mathrm{Kg}$ e que os receptores GABAérgicos de baratas são cerca de 59 vezes mais sensíveis ao fipronil do que os receptores $G_{A B A_{A}}$ de ratos.

\section{Organismos aquáticos}

GUNASEKARA et al. (2007) fizeram uma revisão sobre a toxicidade do fipronil em organismos aquáticos e observaram que esse inseticida é altamente tóxico para muitas espécies, além de bioacumular em algumas. Quantidades em ppt (ng/L) podem afetar microcrustáceos como Daphnia sp e em ppb ( $\mu \mathrm{g} / \mathrm{L})$ podem afetar os peixes de água doce, como o Bluegill sunfish. $\mathrm{A} \mathrm{CL}_{50}$ para $D$. pulex é aproximadamente $16 \mu \mathrm{g} / \mathrm{L}$. O fipronil pode levar ao declínio do crescimento de população de moscas que usam o meio aquática para a 
reprodução, e a extinção destas pode ser observada com 80 g/L (STARK; VARGAS, 2005; GUNASEKARA et al., 2007).

BEGGEL et al (2010) observaram que o fipronil apresenta $\mathrm{CL}_{50}$ de $130 \mathrm{\mu g} / \mathrm{L}$ em 96h para os peixes de água salgada da espécie Cyprinodon variegatus variegatus (Sheepshead minnow - peixinho do engodo), $83 \mu \mathrm{g} / \mathrm{L} \mathrm{em} 96 \mathrm{~h}$ para os peixes de água dose da espécie Lepomis macrochirus (bluegill sunfish) e 100 $\mu \mathrm{g} / \mathrm{L}$ em 96h para os peixes da espécie Oncorhynchus mykiss (rainbow trout truta arco-íris) provenientes de águas doces, mas que migram em águas salgadas. Além disso, esse inseticida reduziu a habilidade de nado dos peixes, em $24 \mathrm{~h}$ à $\mathrm{CL}_{10}$, sugerindo neurotoxicidade em espécies aquáticas em doses subletais.

\section{$\underline{\text { Aves }}$}

GUNASEKARA et al. (2007) relataram que o fipronil tem se mostrado tóxico, mas de maneira mais suave, a uma gama de aves em intoxicações subagudas e crônicas, pela presença do fipronil na dieta destas. Para algumas aves, esse inseticida pode apresentar baixa toxicidade com a $\mathrm{DL}_{50}$ variando entre 2150 a $1120 \mathrm{mg} / \mathrm{Kg}$.

\section{Mamíferos}

Embora o fipronil seja moderadamente tóxico para ratos e camundongos ( $\mathrm{DL}_{50}$ oral entre 40 e $100 \mathrm{mg} / \mathrm{Kg}$ ), estudos mostram que o fipronil técnico 
(pureza de 97\%) pode ser classificado como tóxico de categoria II e III, dependendo da via de administração. Os sinais comuns de toxicidade aguda em animais são: piloereção, postura curvada, locomoção anormal e diarréia (TERÇARIOL, 2007).

Estudos realizados em ratos mostram $\mathrm{DL}_{50}$, via oral, de 92 e 103 mg/Kg de peso corporal (pc) (machos e fêmeas, respectivamente) e $\mathrm{DL}_{50}$, dérmica (rato) superior a 2000 mg/Kg. Além disso, em doses de 4 e 40mg/Kg pc, via oral (vo), o fipronil apresenta biodisponibilidade proporcional à dose administrada e tem tempo máximo de absorção ( $t_{\text {máx }}$ ) em 5,5h e 36h respectivamente. Esses estudos também mostram que o fipronil possui $t_{1 / 2}$ de eliminação entre 183245h (para a dose de $4 \mathrm{mg} / \mathrm{Kg}$ ) e entre 135-171h (para a dose de 40mg/Kg), além de ampla distribuição em tecidos, com predominância em tecido adiposo (Tabela 1) (IPCS/INCHEM, 1997).

Ainda nesse mesmo estudo, a dose de $4 \mathrm{mg} / \mathrm{Kg} \mathrm{pc}$ (vo) apresentou taxa de $50 \%$ de absorção, enquanto a dose de 150 mg/Kg pc (vo) apresentou 30\% de absorção, por causa da saturação do processo de absorção.

Em estudos de neurotoxicidade aguda (em ratos), a NOEL e LOEL foram 0,5 mg/Kg e $5 \mathrm{mg} / \mathrm{Kg}$, respectivamente, baseado-se na diminuição do estiramento das patas traseiras, sete horas após o tratamento (IPCS/INCHEM, 1997)

A principal via de eliminação é as fezes (45-75\%), mas também pode ser eliminada pela urina (5-25\%). Os metabólitos encontrados são: 1) nas fezes: o próprio fipronil (M\&B 46030), M\&B 46136, RPA 200766 e M\&B 45950; e 2) na urina: M\&B 46136, RPA 200766, M\&B 45950, M\&B 45897 e dois produtos com 
anel aberto desse último metabólito (IPCS/INCHEM, 1997). A via de degradação está ilustrada na Figura 4.

Tabela 1 - Concentração de fipronil (em ppm) encontrado nos diversos tecidos de ratas, após a administração, por via oral, de 4 e $40 \mathrm{mg} / \mathrm{Kg}$ de fipronil.

\begin{tabular}{lcc}
\hline \multirow{2}{*}{ Tecido/órgão } & \multicolumn{2}{c}{ Fipronil } \\
\cline { 2 - 3 } & $4 \mathrm{mg} / \mathrm{Kg}$ & $40 \mathrm{mg} / \mathrm{Kg}$ \\
\hline Tecido adiposo & 31 & 200 \\
Adrenais & 10 & 47 \\
Fígado & 8 & 32 \\
Pâncreas & 5 & 32 \\
Tireóide & 4 & 16 \\
Ovários & 6 & 44 \\
Sangue cardíaco & 0,6 & 5 \\
\hline
\end{tabular}

(Fonte: IPCS/INCHEM, 1997)

Quanto aos seres humanos, os dados de toxicidade são baseados em relatos de casos. Um desses relatos descreveu como sintomas induzidos pelo fipronil a dor de cabeça, náuseas, vertigens, reações oculares, respiratórias, gastrointestinais e fraqueza, que foram rapidamente revertidos (TINGLE, 2003).

SZEGEDI et al. (2005) sugerem que as maiores causas de intoxicação humana por fipronil são acidentais e ocupacionais, apresentando efeitos moderados e temporários. As crianças são muito mais sensíveis aos efeitos tóxicos de qualquer praguicida, e mesmo que não apresentem sintomas clínicos, elas podem apresentar baixo desempenho em testes neurocomportamentais. Por isso, é preconizada a utilização de testes 
neurocomportamentais para a avaliação de neurotoxicidade por agentes químicos, como o fipronil (TERÇARIOL, 2007).

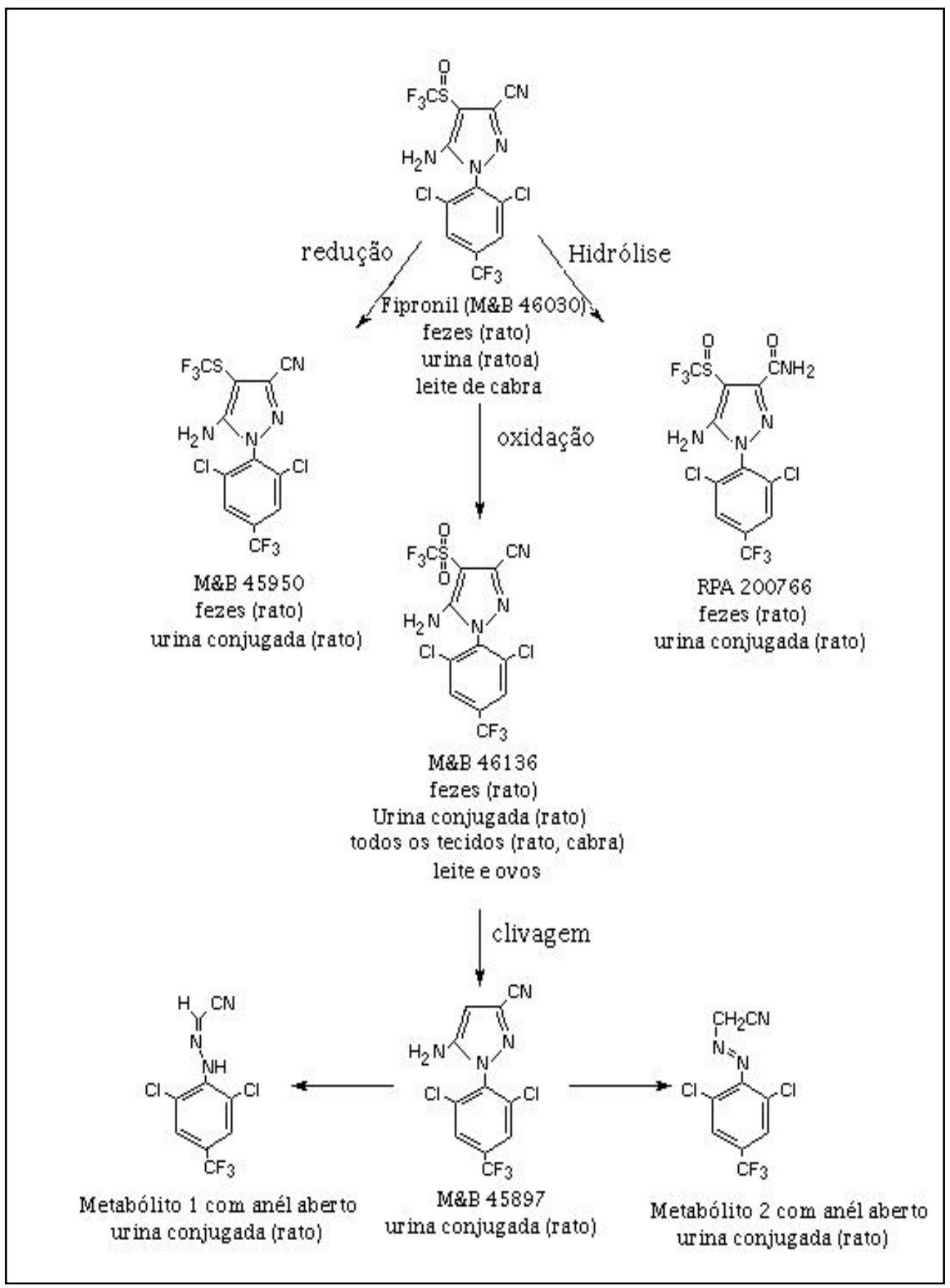

Figura 4: Vias de degradação do fipronil no organismo dos mamíferos (Adaptado de IPCS/INCHEM, 1997) 


\section{Toxicidade reprodutiva}

Muitos agentes químicos afetam o sistema reprodutor causando alterações na gestação, parto e lactação e alterações no desenvolvimento da prole (TERÇARIOL, 2007).

TINGLE et al. (2003) observou que o fipronil, por atuar sobre a tireóide (e assim sobre o metabolismo basal), sobre o fígado e glândula pituitária, levou à diminuição do tamanho da ninhada, bem como diminuiu o peso corporal dos animais e a porcentagem de acasalamento; reduziu o índice de fertilidade, a sobrevivência pós-implantação e pós-natal da prole, além de retardar o desenvolvimento desta.

OHI et al. (2004) demonstraram que os efeitos adversos do fipronil, sobre o aparelho reprodutor das ratas expostas, estão relacionados às alterações no sistema endócrino.

TERÇARIOL (2007) observou que o fipronil pode causar prejuízos ao desenvolvimento embriofetal, alterações fisiológicas e comportamentais por interferir com a síntese de esteróides (a enzima CYP19 aromatase), que catalisa a conversão de andrógenos em estrógenos, sendo responsável pelo balanço homeostático entre os hormônios femininos e masculinos. 


\subsection{Toxicologia do desenvolvimento}

A toxicologia do desenvolvimento é um termo relativamente recente encontrado dentro da toxicologia reprodutiva, com raízes na teratologia (GÓRNIAK, 2008; ILO, 2012).

A toxicologia reprodutiva é uma das áreas mais complexas da toxicologia por causa da própria complexidade do processo reprodutivo. Reprodução é o processo biológico que assegura a continuidade das espécies, através do material genético que é passado para as gerações seguintes (MELLO, 2007); portanto, a toxicologia reprodutiva estuda qualquer tipo de interferência, provocada por um toxicante, na capacidade reprodutiva de machos e/ou fêmeas, bem como no desenvolvimento normal da sua progênie (DALLEGRAVE; MELLO, 2007, ILO, 2012).

O processo de desenvolvimento compreende cinco estágios (GÓRNIAK, 2008):

1) Gametogênese: consiste na formação das células germinativas (óvulo e espermatozóide). Esses gametas se fundem durante o processo de fertilização para formar o zigoto.

2) Pré-implantação: no endométrio gravídico ocorrem alterações bioquímicas controladas por hormônios (progesterona e estrógeno) resultando no desenvolvimento endometrial do blastocisto.

3) Implantação: período máximo de 24 horas após ação hormonal, pois é o período em que o útero tem pico de receptividade ao blastocisto. Interferência na implantação resulta quase sempre em embrioletalidade. 
4) Organogênese: período onde há a formação da placa neural, diferenciação das camadas de células e a formação de órgãos maiores. Nessa fase o concepto está altamente susceptível ao aparecimento de malformações; existem ainda picos de susceptibilidade para cada estrutura formada.

5) Período de maturação fetal: ocorre a histogênese, maturação funcional, desenvolvimento dos órgãos e crescimento do concepto. O início dessa fase não significa que todos os órgãos estão completamente formados, mas que todos podem ser reconhecidos.

Os agentes químicos podem afetar o ciclo reprodutivo em qualquer fase podendo causar alterações parentais e também efeitos teratogênicos na prole.

A teratologia se dedica ao estudo das anomalias e malformações ligadas a perturbações do desenvolvimento embrionário ou fetal (SILVA, 2010). Por um longo período, o campo de investigação da teratologia restringiu-se apenas às alterações morfológicas, principalmente as que envolviam o sistema esquelético; sabe-se que malformações não significam apenas anormalidades em tecidos, mas também anormalidades bioquímicas (BERNARDI, 2011) Atualmente a teratologia hoje também abrange as manifestações no retardo do crescimento, alterações funcionais e comportamentais e/ou a morte da prole (GÓRNIAK, 2008).

Portanto, toxicologia do desenvolvimento é a área que estuda os efeitos nocivos causados por agente tóxicos em um concepto em desenvolvimento (GÓRNIAK, 2008). Segundo a Agência de proteção ambiental americana (Environmental Protection Agency - EPA, 1996), é a área da toxicologia que 


\section{Revisão da literatura 41 \\ Toxicologia do desenvolvimento}

evidencia a ocorrência de efeitos adversos no organismo em desenvolvimento que pode ser resultado de uma exposição anterior a concepção (nos pais), durante o desenvolvimento pré-natal ou pós-natal até o período de maturação sexual.

Em outubro de 1994 as agências FDA (US Food \& Drug Admnistration) e ECC (European Economic Community) se reuniram em um workshop promovido pela IPCS/ OECD (International Programme on Chemical Safety / Organisation for Economic Co-operation and Development): Workshop for the Harrmonisation of Risk Assessment for Reproductive and Developmental Toxicity, (Carshalton, Reino Unido) para definir as diretrizes nos estudos de toxicidade reprodutiva e publicaram os novos protocolos de estudos nessa área (OECD Monograph Series on Testing and Assessment No. 17, 1999, RIECKE, 2000).

Para fins de classificação, a toxicidade reprodutiva é subdividida em (GHS, 2011):

a) Efeitos adversos na habilidade ou capacidade reprodutiva: incluem qualquer efeito capaz de interferir com a habilidade ou capacidade reprodutiva, como: alterações no sistema reprodutivo do macho e/ou da fêmea, efeitos adversos no começo da puberdade, na produção e transporte de gametas, anormalidades no ciclo reprodutivo, comportamento sexual, fertilidade e parto, senescência prematura, ou efeitos adversos na lactação ou na via desta.

b) Efeitos adversos no desenvolvimento do filhote: incluem qualquer efeito que possa interferir com o desenvolvimento normal do concepto, mesmo antes ou depois do nascimento, resultante de uma exposição dos pais antes da 
concepção, ou exposição durante o desenvolvimento do filhote (pré-natal ou pós-natal), até o período de maturação sexual.

Esses efeitos podem se manifestar em qualquer momento da vida do organismo. As principais manifestações de toxicidade do desenvolvimento incluem: 1) morte do organismo em desenvolvimento, 2) anormalidades estruturais e comportamentais, 3) crescimento alterado, e 4) deficiência funcional (ILO, 2011). 


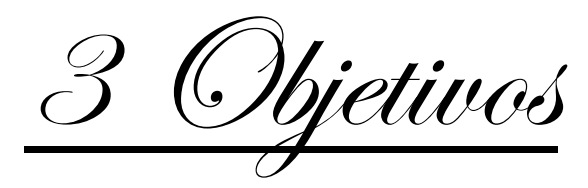

"Há pessoas que transformam o sol numa simples mancha amarela, mas há também aquelas que fazem de uma simples mancha amarela o próprio sol."

(Pablo Picasso) 


\subsection{Objetivo Geral}

O objetivo desse estudo foi avaliar os efeitos tóxicos na prole de ratas expostas ao fipronil durante o período gestacional.

\subsection{Objetivos Específicos}

Avaliar:

- a toxicidade materna por meio do peso gestacional, consumo hídrico e de ração, bem como o desempenho reprodutivo e comportamento maternal;

- o desenvolvimento físico e reflexológico da prole;

- o comportamento da prole na infância e na idade adulta;

- os achados de necropsia da prole. 
A. Material Mêdos

"Senhor, fazei-me instrumento de vossa paz..."

(São Francisco de Assis) 


\subsection{ANIMAIS}

Foram utilizadas ratas Wistar, virgens e adultas (a partir de 90 dias de vida), que foram acasaladas com machos experientes da mesma linhagem (a partir de 100 dias de vida). Esses animais eram provenientes do Biotério do Departamento de Patologia da Faculdade de Medicina Veterinária e Zootecnia da Universidade de São Paulo (FMVZ/USP) e foram alojados em gaiolas moradias de polipropileno ( $38 \times 32 \times 16 \mathrm{~cm})$, forradas com cama de maravalha. As fêmeas foram alojadas em número de quatro animais por gaiola e os machos individualmente.

As gaiolas foram mantidas em salas com exaustão e temperatura de $22 \pm$ $2^{\circ} \mathrm{C}$ controlados por meio de aparelho de ar condicionado central, em um ciclo de 12 horas claro/escuro (luz acessa às 6h00). Água e ração foram fornecidas ad libitum durante todo o procedimento experimental.

Os animais foram utilizados de acordo com as normas e procedimentos éticos relativos ao uso de animais em laboratório da FMVZ/USP (Protocolo CEUA $n^{0} 1924 / 2010$ aceito em 26/05/2010).

\subsection{DROGAS E SOLUÇõES}

O fipronil foi obtido a partir do produto comercial Regent $800 \mathrm{WG}^{\circledR}$, cedido pela empresa BASF (lote 016 - 09 - 06800, data de fabricação 31/01/2009).

A mistura de xilazina $\left(\right.$ Xilazin $\left.^{\circledR}\right)$ e a cetamina $\left(\right.$ Cetamin $\left.^{\circledR}\right)$, ambas da empresa Syntec, foi utilizada nos procedimentos de ovariectomia e eutanásia. 
Foram empregados $5 \mathrm{mg}$ de xilazina associados a $50 \mathrm{mg}$ de cetamina por $\mathrm{Kg}$ de peso corpóreo.

Os medicamentos utilizados no período pós-cirúrgico foram: iodo-povidine, Nebacetim ${ }^{\circledR}$ (Nycomed) e paracetamol.

Foram também utilizados os hormônios progesterona (Sigma) e 17- $\beta$ estradiol (Sigma), e o óleo de amendoim, como veículo desses hormônios.

O fipronil foi dissolvido em água filtrada (em filtro simples) nas concentrações de $0,1,1,0$ e 10,0 mg/mL.

Foi, ainda, utilizada solução salina de cloreto de sódio $(\mathrm{NaCl})$ à $0,9 \%$ nos procedimentos de swab e de lavado vaginal.

\subsection{PROCEDIMENTOS}

\subsubsection{Acasalamento e diagnóstico de prenhez}

As ratas fêmeas, virgens, foram introduzidas na gaiola do macho sexualmente experiente, na proporção de três fêmeas para cada macho, ao final do período claro do dia $(17 \mathrm{~h} 00-18 \mathrm{~h} 00)$. No dia seguinte (entre 7h30 8h00 horas), foi realizado o diagnóstico de prenhez. Para tanto, um swab (uma haste de plástico, com algodão nas extremidades) umedecido em solução salina foi introduzido na vagina da rata (não profundamente, para evitar a pseudoprenhez), a fim de colher a secreção vaginal. Em seguida foi realizado um esfregaço em uma lâmina de vidro, sendo observado ao microscópio óptico (técnica adaptada de MARCONDES; BIANCHI; TANNO, 2002). A presença de 
espermatozóides na lâmina (figura 5) indica o do dia zero de gestação (DG0). As fêmeas diagnosticadas positivas para prenhez foram alojadas individualmente em gaiolas, durante toda gestação, que tem duração de 22 dias, e lactação, que tem duração de 21 dias.

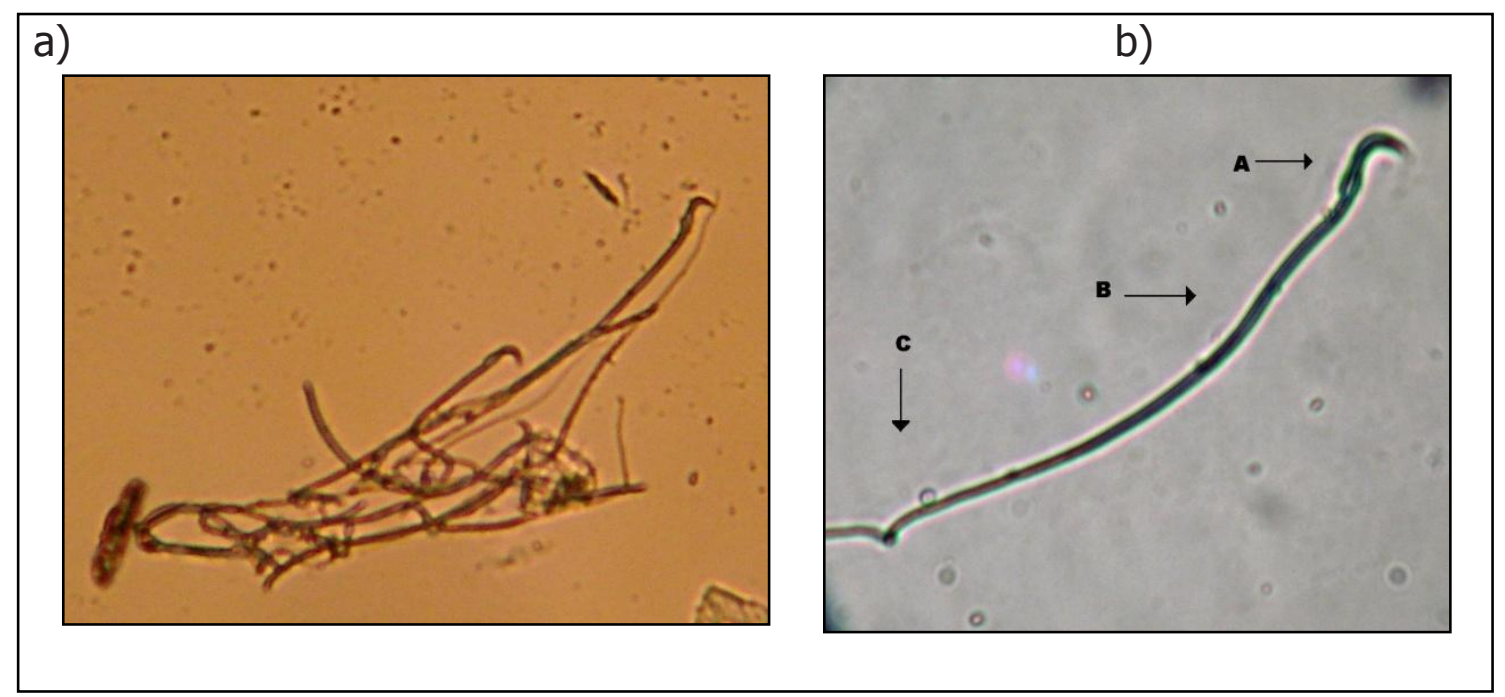

Figura 5: Fotografias de espermatozóides obtidos de swab vaginal de ratas; a) emaranhado de espermatozóides (10x40) e b) estruturas de um espermatozóide (10x100): (A) porção da cabeça; (B) porção intermediária; (C) porção da cauda

\subsubsection{Administração do fipronil}

As soluções de fipronil foram administradas por gavagem (figura 6), diariamente, a partir do sexto dia de gestação (DG6) até o DG20. As fêmeas do grupo controle receberam água filtrada em um volume de $1 \mathrm{~mL} / \mathrm{Kg}$ peso pela mesma via. As administrações foram realizadas sempre no período da manhã, entre $8 \mathrm{~h} 30$ e $10 \mathrm{~h} 00$. 


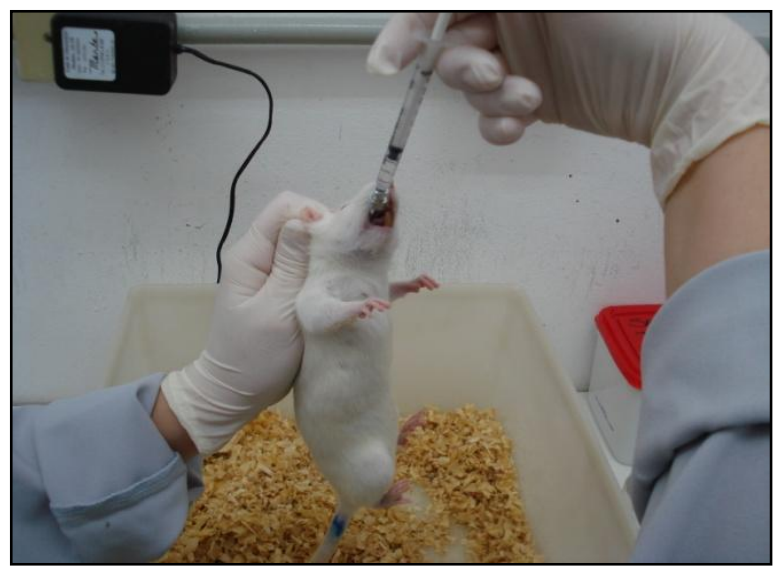

Figura 6: Fotografia de uma administração via oral, por gavagem, em rata

\subsubsection{Comportamento maternal}

O comportamento maternal foi avaliado no $5^{\circ}$ dia pós-nascimento (DPN 5) e realizado sempre no período da manhã, entre $8 \mathrm{~h} 00$ e $10 \mathrm{~h} 00$, em sala isolada de som e com baixa intensidade de luz ambiente.

Neste teste os filhotes foram separados das mães por uma hora e o ninho desmanchado. Após esse período, os filhotes foram recolocados na caixa moradia, sendo posicionados em cada um dos vértices e nos pontos centrais de cada lateral da caixa; a mãe foi, então, introduzida no centro da caixa e o comportamento filmado por $1 \mathrm{~h}$, avaliando os seguintes parâmetros:

- latência, em segundos, para a fêmea buscar o primeiro filhote;

- latência, em segundos, para a fêmea agrupar todos os filhotes;

- porcentagem de mães, por grupo, que recolheram todos os filhotes;

- tempo, em segundos, que a rata permaneceu lambendo o filhote (grooming);

- frequência de auto-limpeza (self grooming) da fêmea; 
- latência, em segundos, para a manifestação do comportamento maternal completo (Full Maternal Behavior - FMB), onde a fêmea permanece em cifose fisiológica por 3 minutos consecutivos, ou mais, amamentando todos, ou pelo menos 5 de seus filhotes;

- porcentagem de fêmeas, por grupo, que manifestaram o comportamento de FMB;

- confecção e qualidade de um novo ninho.

Para a avaliação da qualidade do novo ninho construído, utilizou-se uma escala de escores conforme mostra a Tabela 2.

Tabela 2 - Escores para avaliação da qualidade do novo ninho construído, quando da avaliação do comportamento maternal

\begin{tabular}{lc}
\hline \multicolumn{1}{c}{ Característica do ninho } & Escore \\
\hline Não houve confecção de novo ninho & 0 \\
Ninho bastante superficial, sem paredes de maravalha & 1 \\
Ninho pouco profundo, com baixas paredes de maravalha & 2 \\
Ninho profundo, com paredes altas de maravalha e até mesmo & 3 \\
encobrindo os filhotes & \\
\hline
\end{tabular}

\subsubsection{Desenvolvimento físico e reflexológico}

O desenvolvimento físico e reflexológico dos filhotes são baseados em observações do dia do aparecimento de cada parâmetro, exceto o reflexo de pressão palmar, onde se verifica o dia do desaparecimento deste (Tabela 3). 
Esses parâmetros foram acompanhados em um casal de cada ninhada, escolhido ao acaso; eles foram identificados com nanquim em uma das patas do membro pélvico, no segundo dia pós-nascimento (DPN2) (Figura 7), e foram os representantes da ninhada em todos os parâmetros do desenvolvimento.

As observações foram realizadas diariamente no período da manhã, entre 9h e 11h, desde o dia do nascimento (DPN0) até o DPN35 (duas semanas depois do desmame), que indica o inicio da fase puberal. Além dos parâmetros apresentados pela Tabela 3, o casal ainda foi pesado nos DPN2, 7, 14, 21, 28 e 35.

Tabela 3 - Parâmetros do desenvolvimento físico e as datas do início da observação de cada parâmetro

\section{Parâmetros}

Dia que se inicia

a observação

\section{Físico}

Desdobramento da orelha (Figura 8a)

DPN2

Aparecimento dos pêlos (Figura 8b)

DPN6

Erupção dos dentes incisivos superiores e inferiores (Figura 8c)

DPN8

Abertura bilateral dos olhos (Figura 8d)

DPN9

Andar adulto

DPN10

Descida de testículos

DPN18

Abertura vaginal

DPN30

Reflexológico

Pressão palmar

DPN2

Endireitamento postural

DPN4

Geotaxia negativa

DPN5 
Sobre o parâmetro de andar adulto, este foi considerado como o dia que o animal conseguiu andar sobre uma superfície plana, apoiada sobre as quatro patas, sem encostar o ventre na superfície.

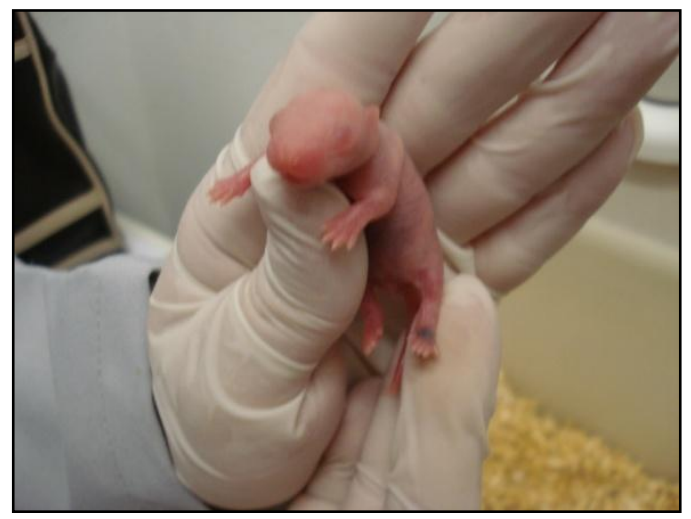

Figura 7: Fotografia de um filhote de rata identificado com nanquim em uma das patas do membro pélvico
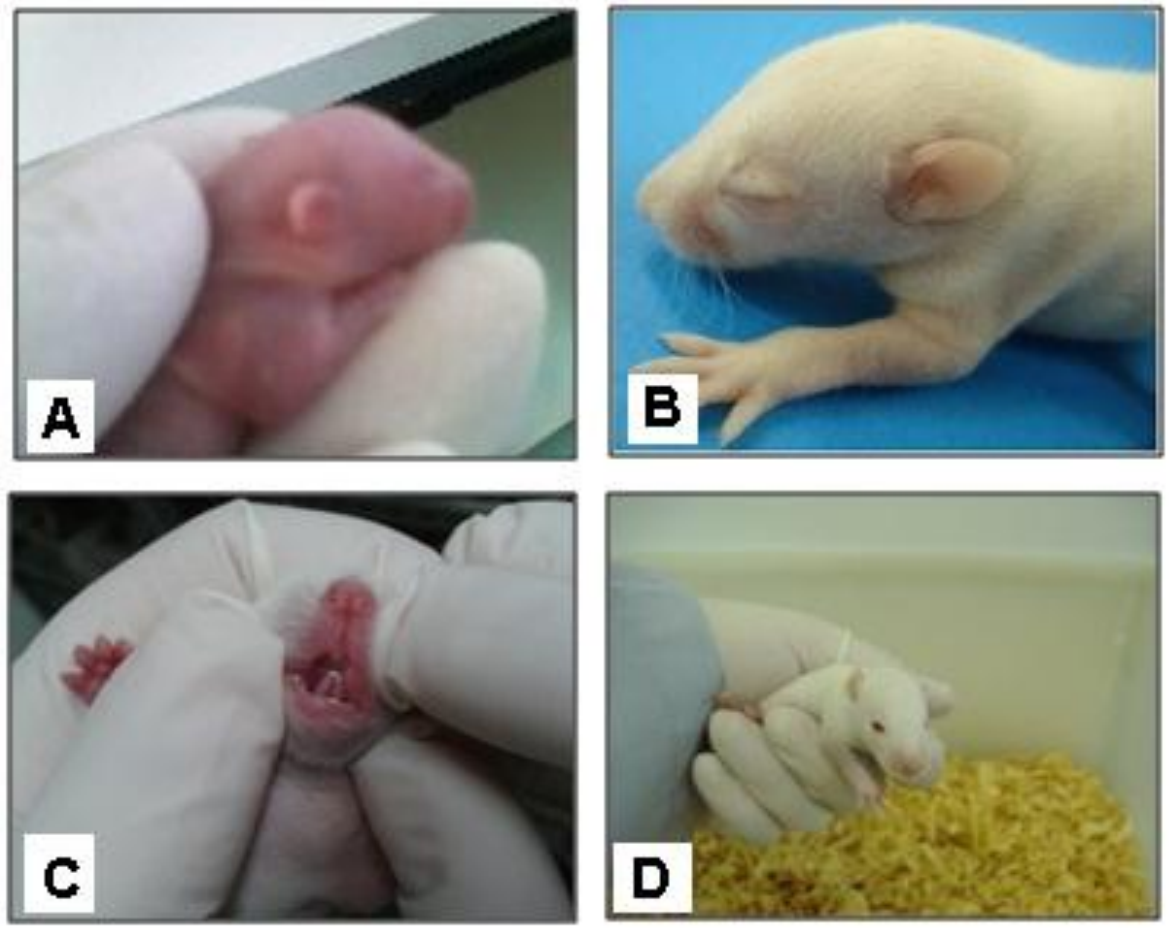

Figura 8: Fotografias dos parâmetros do desenvolvimento físico observados: A) desdobramento da orelha; B) aparecimento de pêlos; C) erupção dos dentes incisivos; D) abertura dos olhos 
Descrição dos parâmetros do desenvolvimento reflexológico

Em relação ao parâmetro de pressão palmar, se observa o dia que o animal deixa de fechar a pata quando esta é tocada pela ponta de um clipes (Figura 9a).

O reflexo de endireitamento consiste em colocar o animal em decúbito dorsal e registrar o dia que ele conseguiu virar o corpo para a posição de decúbito ventral. 0 período de latência máximo para a realização este teste é de 30 segundo.

O reflexo de geotaxia negativa consiste em colocar o filhote sobre uma rampa de aproximadamente $45^{\circ}$ de inclinação, a $5 \mathrm{~cm}$ da base de apoio dessa superfície, com a cabeça direcionada para baixo (Figura 9b). Anotou-se o dia em que o animal voltou à posição oposta, dirigindo sua cabeça para cima. Quando 0 animal não apresentou 0 reflexo na $1^{\circ}$ tentativa (cuja latência máxima foi de 1 minuto), ele foi testado mais 2 vezes com a mesma latência.
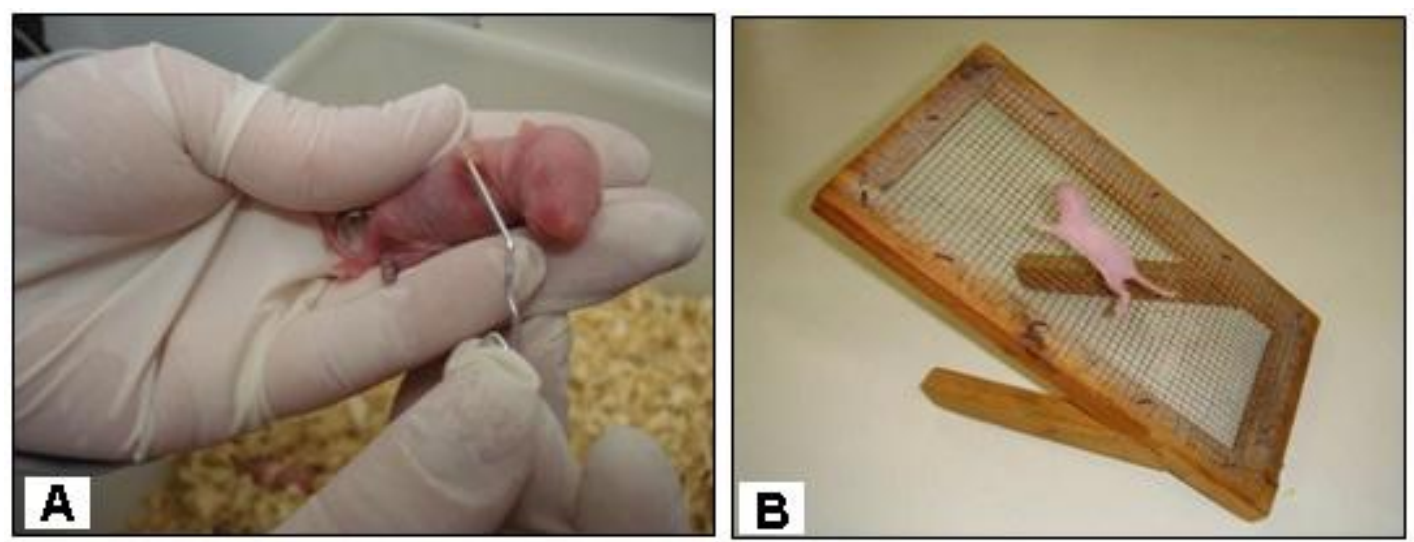

Figura 9: Fotografias dos parâmetros do desenvolvimento reflexológico observados: A) pressão palmar; B) geotaxia negativa 


\subsubsection{Campo aberto}

O teste de campo aberto foi realizado em um aparato circular de madeira com $97,0 \mathrm{~cm}$ de diâmetro e 32,5 cm de altura, pintado de branco. 0 fundo desta arena é dividido por linhas em três círculos concêntricos e segmentos de reta, em 25 subunidades (Figura 10). Este aparato estava localizado em sala isolada de som e com baixa intensidade de luz ambiente.

Cada animal, isoladamente, foi colocado no centro da arena e observado por 3 ou 5 minutos (infância e idade adulta, respectivamente), sempre no período da manhã, entre as 9 h00 e 11 h00, intercalando-se os animais do grupo controle e aqueles dos grupos experimentais. Durante a infância os animais foram avaliados quanto ao perfil de atividade geral, do DPN15 ao DNP21 e na idade adulta a atividade geral foi avaliada no DPN75.

Os parâmetros avaliados no campo aberto foram:

- frequência de locomoção: define-se como uma unidade de locomoção o ato de o animal penetrar com os quatro membros locomotores em uma das subdivisões do chão da arena;

- frequência de levantar: quantas vezes o animal adquiriu a postura de apoiar sobre os membros pélvicos, com o tronco perpendicular ao chão, cabeça dirigida para cima, podendo ou não tocar na parede do campo aberto;

- frequência de auto-limpeza (self grooming): quantas vezes o animal lambeu as patas e/ou pêlos, fazendo a sua higiene;

- tempo de imobilidade: quanto tempo o animal permaneceu imóvel. 
Para o parâmetro de tempo de imobilidade utilizou-se escores, conforme ilustrado na Tabela 4.

Tabela 4 - Escores atribuídos ao tempo de imobilidade do animal em campo aberto

\begin{tabular}{cc}
\hline Tempo (segundos) & Escore \\
\hline $0-24$ & 1 \\
$25-48$ & 2 \\
$49-72$ & 3 \\
$73-96$ & 4 \\
$97-120$ & 5 \\
$121-144$ & 6 \\
$145-168$ & 7 \\
$>168$ & 8 \\
\hline
\end{tabular}

Entre as observações de cada animal, a arena foi higienizada com álcool etílico $5 \%$ para que o rastro do animal anterior não interferisse na resposta comportamental do próximo animal.

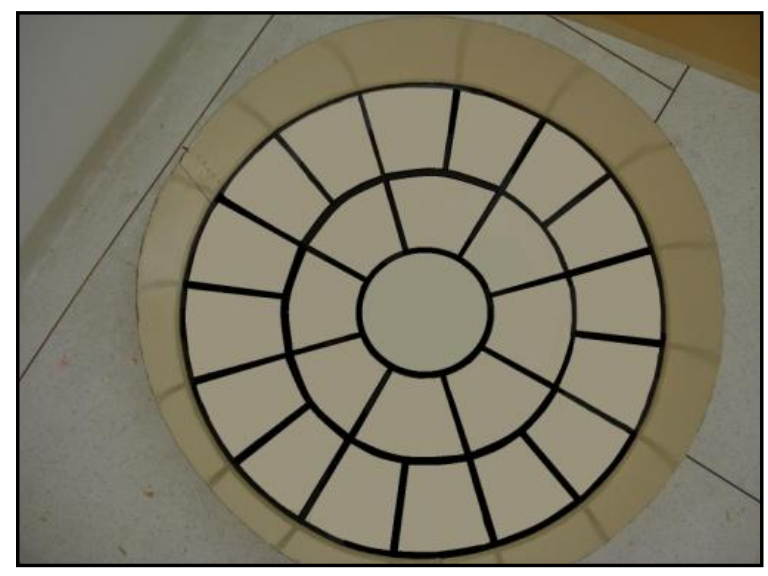

Figura 10: Fotografia da arena de campo aberto 


\subsubsection{Labirinto em cruz elevado}

O aparato de labirinto em cruz elevado (LCE) consiste em uma plataforma de madeira pintada de preto, elevada a $55 \mathrm{~cm}$ do chão, em forma de cruz, com dois braços abertos (BA - sem proteção lateral, medindo $30 \times 5 \mathrm{~cm}$ ) ortogonais a dois braços fechados (BF, com paredes verticais, medindo $30 \times 5 \times 15 \mathrm{~cm}$ ), e uma zona central que comunica os quatro braços (medindo $5 \times 5 \mathrm{~cm}$ ) (Figura 11). Este aparato estava localizado em sala isolada de som e com baixa intensidade de luz ambiente.

Cada animal foi colocado, isoladamente, sempre no período da tarde, entre $14 \mathrm{~h} 30$ e 17h00, na zona central da arena e os seguintes parâmetros foram registrados:

- número de entradas no $\mathrm{BA}$ e $\mathrm{BF}$, considerando uma entrada quando o animal está com os quatro membros locomotores no braço;

- tempo de permanência no BA e no BF;

- Head-dipping: frequência em que o animal apresenta o comportamento de estirar o corpo e mergulhar a cabeça para fora dos limites da plataforma de $\mathrm{BA}$;

- Stretched attend posture (SAP): frequência em que o animal estira o corpo para farejar outra área sem sair da qual se encontra.

A partir desses dados foram calculadas:

- porcentagem de entradas nos braços abertos: $n^{0}$ de entradas nos BA / ( $n^{0}$ de entradas nos BA + BF) $\times 100$; 
- porcentagem de tempo nos braços abertos: tempo nos BA / (tempo nos $B A+B F) \times 100$.

Após avaliação de cada animal, o aparato foi higienizado com uma solução de álcool etílico a 5\%.

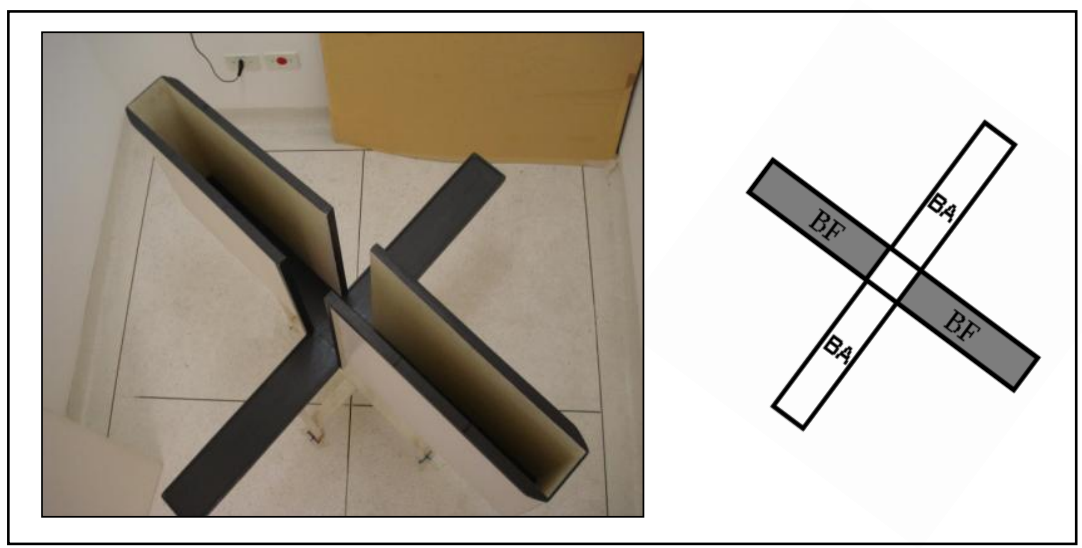

Figura 11: Fotografia do aparato de labirinto em cruz elevado, mostrando suas divisões: $\mathrm{BF}=$ Braço fechado, $\mathrm{BA}=$ Braço aberto

\subsubsection{Interação social}

A avaliação do tempo de interação social (IS) foi realizada na idade adulta do animal (DPN 100), no próprio aparelho de campo aberto, que estava localizado em sala isolada de som e com alta intensidade de luz ambiente.

A IS foi avaliada por meio de observação direta, de duplas de animais de mesmo sexo e de peso corpóreo semelhante (a diferença de pesos não deve ultrapassar $10 \mathrm{~g}$ ), que nunca estiveram em contanto um com o outro e que receberam o mesmo tratamento. 
Dois dias antes do teste, cada animal foi colocado individualmente na arena do campo aberto para habituação no aparato. No dia seguinte os animais foram colocados aos pares para habituação com seu respectivo par e após 24 h o teste foi efetivamente realizado. Os animais permaneceram sempre por 10 minutos no aparato.

O tempo de interação social consistiu na somatória, em segundos, dos tempos gastos em: cheirar, passar por cima ou subir no parceiro, coçar o parceiro, grooming mútuo, investigação genital do parceiro, seguir e caminhar em volta ou junto ao parceiro.

\subsubsection{Coordenação motora em trave elevada}

A avaliação de coordenação motora foi realizada na trave elevada, conforme descrito por RODRIGUES-ALVES et al. (2009). Sucintamente, este aparato consiste em uma trave de madeira medindo $2 \mathrm{~m}$ de comprimento, $2 \mathrm{~cm}$ de largura e espessura e, em cada extremidade, há uma plataforma quadrada de $10 \mathrm{~cm}^{2}$ por $2 \mathrm{~cm}$ de espessura. Essa trave fica apoiada sobre pés de $20 \mathrm{~cm}$ de altura, posicionados sob as plataformas e no centro da trave. 0 aparato é pintado de branco e possui duas marcas verticais vermelhas, delimitando o comprimento de $1 \mathrm{~m}$ na porção central (Figura 12).

Cada animal foi treinado por 5 minutos diariamente, por cerca de 10 dias, a atravessar sobre a trave, recebendo nas plataformas, uma recompensa (grãos de milho verde) pela travessia. Dá-se por encerrado o período de treinamento quando o animal consegue ir e voltar na trave, sem parar, por duas vezes (4 
travessias). Os ratos que não conseguem realizar a travessia em 10 dias de treinamento são eliminados do experimento.

O desempenho do animal na trave foi avaliado através de uma escala de escores (Tabela 5) referente ao caminhar na porção central da trave. Assim, atribuiu-se um escore para cada passo dado com o membro pélvico voltado para o observador. Ao término de cada sessão, somam-se os escores obtidos por cada animal.

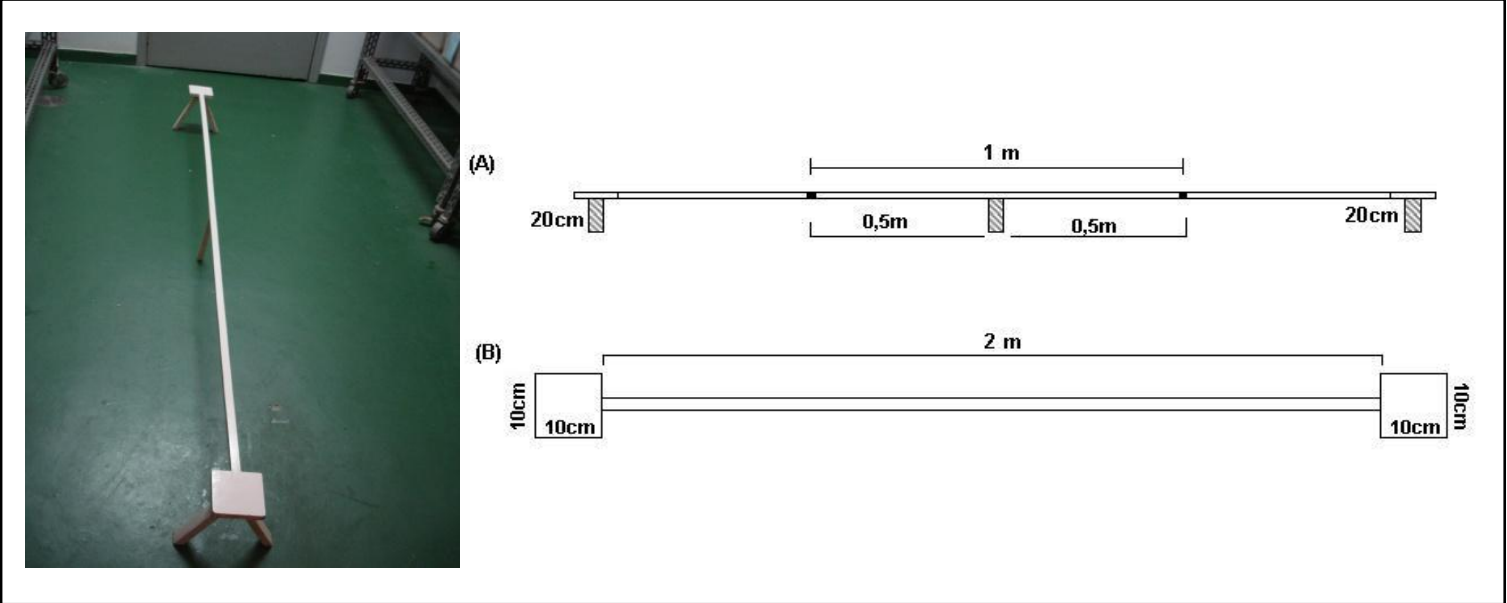

Figura 12: Fotografia mostrando o aparato de trave elevada e esquema ilustrativo: $(A)$ vista lateral; (B) vista de cima.

Tabela 5 - Escores atribuídos ao caminhar do animal na porção central da trave levada

\begin{tabular}{cc}
\hline Escore & Posição do membro pélvico \\
\hline 0 & Normal \\
1 & Posicionado no limite da espessura da trave \\
2 & Posicionamento abaixo do limite da trave \\
\hline (RODRIGUES-ALVES et al., 2009).
\end{tabular}




\subsubsection{Avaliação do ciclo estral}

O ciclo estral foi acompanhado por observações microscópicas diárias, por 21 dias consecutivos, do material proveniente do lavado vaginal. As coletas de secreções vaginais foram realizadas no período da manhã ( 8 h30 as 10h00), conforme descrito por MARCONDES, BIANCHI e TANNO (2002). Sucintamente, $10 \mu \mathrm{L}$ de solução salina ( $\mathrm{NaCl} 0,9 \%)$ foi introduzida na vagina com o auxilio de uma pipeta de plástico (mas não profundamente), sendo coletada a secreção vaginal da rata. Uma gota desse fluido vaginal coletado foi depositada em lâmina de vidro e, instantaneamente, observada sob microscopia de luz (10x40). Três tipos celulares são possíveis de ser reconhecidos: 1) células epiteliais redondas e nucleadas; 2) células queratinizadas, irregulares e anucleadas; e 3) leucócitos pequenos e circulares, bem definidos. As diferentes fases do ciclo estral são, então, caracterizadas por diferentes proporções desses tipos celulares:

- fase de proestro caracteriza-se pela predominância de células epiteliais nucleadas (Figura 13a).

- fase de estro (fase onde a fêmea está totalmente receptiva para cópula) caracteriza-se, principalmente, pelas células queratinizadas, anucleadas com formato de "floco" (Figura 13b).

- fase de metaestro apresenta uma mistura de células. Nessa fase há a presença de leucócitos, células queratinizadas e algumas células epiteliais nucleadas (Figura 13c). 
- fase de diestro caracteriza-se pela predominância de leucócitos, restos celulares e secreção (Figura 13d).

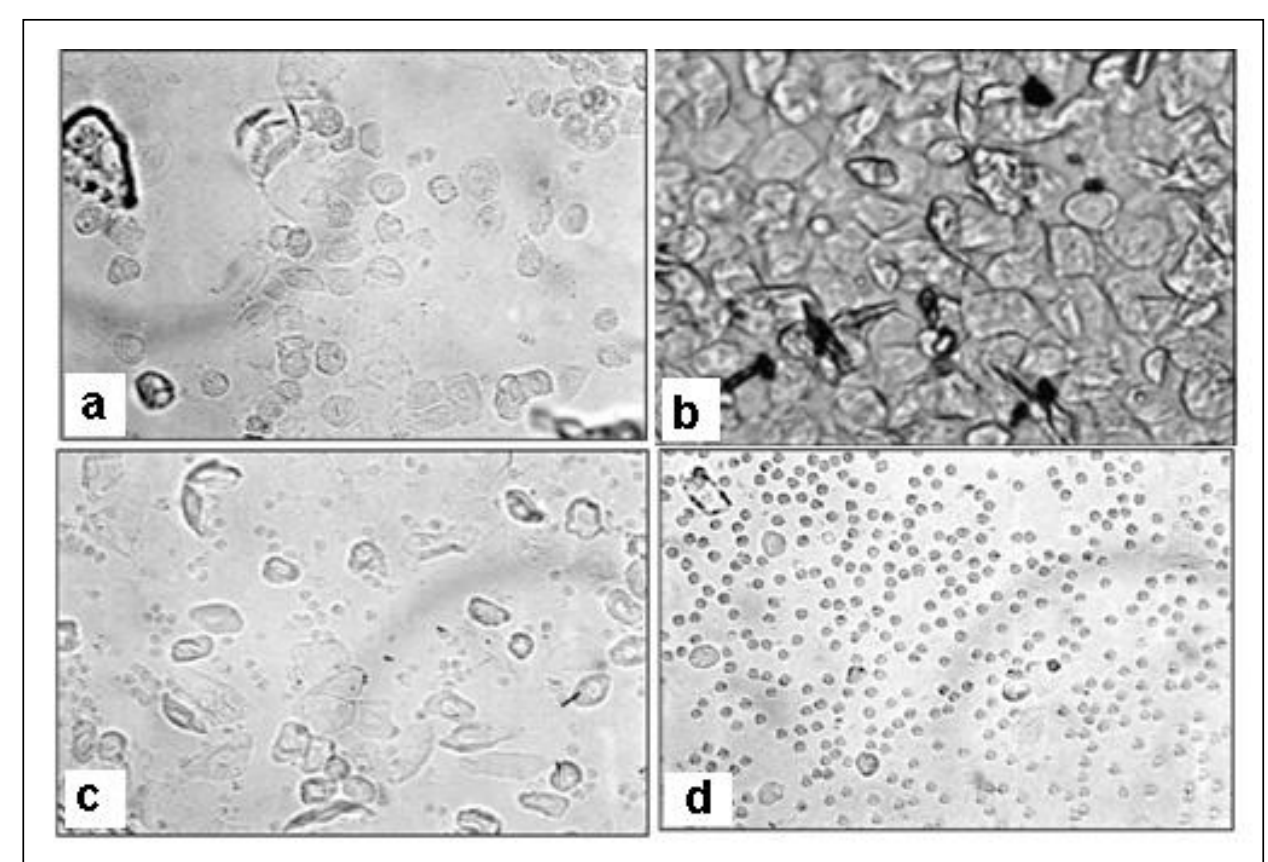

Figura 13: Diferentes fases do ciclo estral de ratas: a) Proestro; b) Estro; c) Metaestro; d) Diestro (adaptado de MARCONDES; BIANCHI; TANNO, 2002),

\subsubsection{Ovariectomia}

Os materiais utilizados nessa técnica foram: instrumentação cirúrgica, plataforma cirúrgica (placa de parafina), mistura anestésica (xilazina:cetamina), iodo-povidine, Nebacetin ${ }^{\circledR}$, paracetamol.

A técnica empregada, descrita por STEELE e BENNETT (2011), consiste em anestesiar a rata, monitorando a função respiratória para evitar depressão acentuada, até que ela tenha perdido os reflexos dolorosos da ponta da cauda e de pressão na pata anterior. Em seguida o animal foi colocado na plataforma cirúrgica (coberta com uma camada de filme transparente e higienizada com 
álcool 70\%), em decúbito lateral e foi realizada a tricotomia na região dorsolateral, entre o rebordo costal inferior e a coxa, fazendo a assepsia desta região com iodo-povidine. Fez-se uma incisão de aproximadamente dois centímetros na pele e tecido celular subcutâneo a cerca de quatro centímetros lateralmente à linha mediana. A seguir, fez-se uma incisão na parede muscular até ter acesso à cavidade abdominal, localizando o ovário em meio a uma massa gordurosa. A retirada do ovário foi realizada após ligadura da extremidade do corno uterino, seccionando entre a ligadura e o ovário. Após esse procedimento, o útero foi recolocado na cavidade abdominal, suturando a parede muscular e, em seguida, a pele. O procedimento foi repetido do outro lado, para a retirada do segundo ovário. Encerrada a retirada do segundo ovário, a assepsia foi repetida e uma camada de Nebacetin ${ }^{\circledR}$ foi aplicada sobre os pontos. A rata foi então colocada em uma caixa moradia limpa e coberta com uma folha de papel toalha, levemente aquecida, para se evitar a hipotermia pós-cirúrgica. Esse animal foi mantido com uma mistura de água e paracetamol (20 gotas para cada $100 \mathrm{~mL}$ de água filtrada $-2,6 \mathrm{mg} / \mathrm{mL}$ ) por três dias e ração ad libitum. Os animais foram acompanhados diariamente quanto à cicatrização da pele e recuperação pós-cirúrgica.

\subsubsection{Comportamento sexual}

Para a avaliação do comportamento sexual, tanto da prole feminina quanto da prole masculina, foi preciso que os animais estivessem habituados (no

mínimo três semanas) em uma sala com o ciclo de $12 \mathrm{~h}$ claro/escuro 
parcialmente invertido, ou seja, as luzes se apagavam às $10 \mathrm{~h}$ e acendiam $22 \mathrm{~h}$. O comportamento foi avaliado sempre no período das $15 \mathrm{~h}$ às $19 \mathrm{~h}$, em uma caixa de madeira (56 x $32 \times 32 \mathrm{~cm}$ ) com uma tampa móvel e uma face frontal de vidro (RODRIGUES-ALVES et al., 2008), colocada numa sala iluminada por duas lâmpadas infravermelhas de $25 \mathrm{~W}$ cada.

O comportamento sexual feminino foi avaliado, conforme descrito LEMINI e CANCHOLA (2009). Assim, um macho sexualmente experiente foi colocado na caixa teste e aclimatado por 3 minutos. Em seguida a fêmea a ser avaliada foi introduzida na caixa. Foi permitido que o macho realiza-se 10 montas na fêmea e o número de lordoses (comportamento de levantar da cabeça, arquear o dorso para trás e deslocar a cauda para o lado) apresentadas por ela foi registrado. Foi-se, então, calculado o coeficiente de lordose $(\mathrm{CL})$ (número de lordoses/número de montas x 100) como parâmetro da receptividade sexual dessa fêmea.

O comportamento sexual masculino foi avaliado conforme descrito por AGMO (1997) e RODRIGUES-ALVES (2008). Sucintamente, o rato macho, virgem, a ser avaliado foi aclimatado na caixa teste por 5 minutos. Em seguida, uma fêmea ovariectomizada, sexualmente ativada com estradiol $(50 \mu \mathrm{g} / \mathrm{Kg}, \mathrm{SC}$, $54 \mathrm{~h}$ antes da realização do teste) e progesterona $(2,0 \mathrm{mg} / \mathrm{Kg}, \mathrm{SC}, 6 \mathrm{~h}$ antes da realização do teste) foi introduzida na caixa e o comportamento sexual foi avaliado por um período de 40 minutos. Os parâmetros observados foram os seguintes:

- latência para a primeira monta, sem intromissão vaginal do pênis (LPM); 
- latência para a primeira intromissão (LPI): A intromissão é inferida pela observação do padrão motor característico, isto é, monta com movimento profundo da pélvis e desmonta rápida, acompanhado de lordose da fêmea e, após a desmonta, observa-se limpeza genital do macho;

- número de montas incompletas (MI): número total de montas sem intromissão até a primeira ejaculação;

- número de intromissões (NI): número total de montas com intromissão vaginal até a primeira ejaculação, incluindo a intromissão ejaculatória;

- latência para a primeira ejaculação (LPE): considera-se ejaculação uma monta com duração superior a dois segundos, lordose da fêmea, levantar e balouçar do tronco pelo macho, seguida de ausência de interesse sexual nos minutos seguintes;

- latência para primeira monta pós-ejaculatória (LPMP): tempo decorrido a partir da primeira ejaculação até a primeira monta (período refratário duração normal entre 4 e 8 min);

- latência para a primeira intromissão pós-ejaculatória (LPIP);

- número total de montas, incompletas e com intromissão, até o final do tempo de observação;

- número total de ejaculações (NE): número de ejaculações realizadas pelo animal no tempo total de observação.

As latências foram registradas com o auxilio de um cronômetro manual. Foram calculados, com estes parâmetros, somente para os animais que ejacularam pelo menos uma vez durante o período de observação os seguintes índices: 
- número total de montas até a primeira ejaculação (TM): obtido pela soma de MI com NI;

- número total de montas no tempo de 40 min (TMT): é a soma de todas as montas incompletas e intromissões em todo o tempo de observação, isto é, $T M T=M I+N I+M I P+N I P ;$

- frequência de montas por minuto: calculada pela razão entre TM e (LPELPM);

- frequência de intromissões por minuto: calculada pela razão entre NI e (LPE-LPM)

-intervalo inter-intromissões: é calculara pela razão entre a LPE e NI

- eficiência copulatória (EC em \%): é calculada pela a razão entre NI e TM, vezes 100 , isto é, $\mathrm{EC}=(\mathrm{NI} / \mathrm{TM}) \times 100$.

Os animais que não apresentaram o comportamento de monta, ou interesse sexual pela fêmea (investigação da genitália feminina), em 5 minutos, foram considerados como não responsivo ao teste.

\subsubsection{Necropsia}

Os animais, ao final de cada experimento, foram submetidos à eutanásia com anestesia profunda (com a mistura de xilasina:cetamina). Foi aberta a cavidade abdominal e torácica da prole de ratas expostas ao fipronil durante a gestação, para avaliação macroscópica dos órgãos, sendo, a seguir estes retirados e pesados. As fêmeas foram submetidas à eutanásia na fase de estro. 
O peso relativo dos órgãos foi então calculado (peso do órgão / peso corporal x 100).

Os órgãos investigados foram: fígado, baço, rins, adrenais, ovários, útero, cérvix uterina, próstata, testículos e tireóide.

\subsubsection{Análise estatística}

Os resultados foram apresentados em média e respectivos erros padrão ou porcentagens. A homocedasticidade foi verificada por meio no teste $\mathrm{F}$ ou de Bartlet. A normalidade foi verificada pelo teste de Kolmogorov-Smirnov. Foram utilizados os seguintes testes: análise de variância (ANOVA) de uma e duas vias, Kruskal-Wallis, Dunnett, Bonferroni e Qui-quadrado.

As diferenças foram consideradas estatisticamente significantes sempre que $p<0,05$.

Para as análises estatísticas foram empregados os softwares GraphPad Prism v5.00@ para Windows, San Diego, Califórnia. 
5 Delineamento experimentale

\author{
OResultados
}

"Dificuldades são prêmios de Deus à nossa inteligência"

(Paiva Neto) 
A seguir, são apresentados o delineamento experimental e os resultados subdivididos em três partes. A primeira contém os dados referentes aos efeitos do fipronil sobre a mãe; a segunda parte está relacionada à investigação dos efeitos do fipronil no desenvolvimento e na infância da prole; e a terceira parte está relacionada à investigação dos efeitos do fipronil na prole adulta.

5.1 PARTE 1-Efeitos do fipronil sobre a rata prenhe e no comportamento maternal

\section{Experimento 5.1.1: Efeito da administração de fipronil, durante a gestação, nos parâmetros reprodutivos de ratas}

Quarenta ratas Wistar, adultas (a partir de 90 dias de vida), virgens, foram acasaladas e, quando diagnosticada a prenhez, foram alojadas individualmente em caixas moradias com água e ração sendo fornecidas ad libitum (item 4.3.1).

Os animais foram, então, separados em três grupos experimentais, que receberam diferentes doses de fipronil $(0,1,1,0$ e $10,0 \mathrm{mg} / \mathrm{Kg})$ e um grupo controle que recebeu água filtrada ( $1 \mathrm{~mL} / \mathrm{Kg}$ peso), por gavagem, do DG6 ao DG20 ( $\mathrm{n}=10$ animais/grupo). Os seguintes parâmetros foram avaliados: consumo de água e ração, peso gestacional, duração de gestação, tamanho de ninhada e o número de fêmeas e machos nascidos. 
A Tabela 6 mostra o consumo de água de ratas exposta ao fipronil durante a gestação. A ANOVA de duas vias mostrou não haver diferenças significantes entre os grupos.

A Figura 14 mostra o consumo de ração das ratas exposta ao fipronil durante a gestação. A ANOVA de duas vias mostrou diferenças significantes entre os grupos em relação ao tratamento $(F(3 / 116)=7,16, p<0,01)$ e em relação à semana $(F(2 / 116)=9,93, p<0,001)$, não havendo interação entre os fatores. O teste de Bonferroni mostrou que as fêmeas que receberam $10 \mathrm{mg} / \mathrm{Kg}$ de fipronil apresentaram redução significante do consumo de ração na segunda semana de gestação $(p<0,01)$, quando comparadas às fêmeas do grupo controle.

Tabela 6 - Consumo semanal de água de ratas prenhes expostas ou não (controle) ao fipronil, do $6^{\circ}$ dia ao $20^{\circ}$ dia de gestação. Dados apresentados em médias e seus respectivos erros padrão ( $n=$ número de animais)

\begin{tabular}{ccccr}
\hline \multirow{2}{*}{ Semana } & Controle & \multicolumn{3}{c}{ Fipronil $(\mathrm{mg} / \mathrm{Kg})$} \\
\cline { 3 - 5 } & $(\mathrm{n}=11)$ & $0,1(\mathrm{n}=11)$ & $1,0(\mathrm{n}=10)$ & $10,0(\mathrm{n}=13)$ \\
\hline $1^{\mathrm{a}}$ & $266,3 \pm 27,68$ & $256,0 \pm 19,18$ & $261,5 \pm 11,89$ & $259,5 \pm 14,27$ \\
$2^{\mathrm{a}}$ & $339,9 \pm 38,14$ & $333,9 \pm 27,48$ & $330,0 \pm 17,15$ & $319,8 \pm 16,24$ \\
$3^{\mathrm{a}}$ & $366,6 \pm 27,50$ & $421,5 \pm 28,45$ & $388,1 \pm 15,29$ & $395,3 \pm 33,66$ \\
\hline
\end{tabular}

ANOVA de duas vias: $p>0,05$

A Tabela 7 mostra o peso gestacional semanal de ratas exposta ao fipronil durante a gestação. A ANOVA de duas vias mostrou não haver diferenças significantes entre os grupos. 


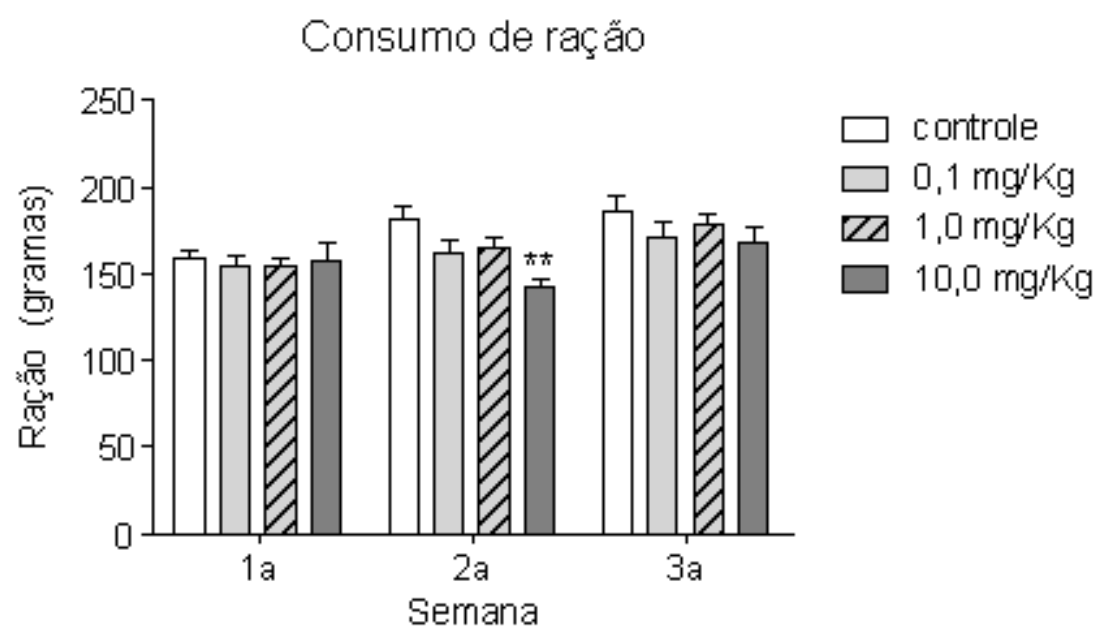

Figura 14: Consumo semanal de ração das ratas prenhes expostas ou não (controle) ao fipronil, do $6^{\circ}$ dia ao $20^{\circ}$ dia de gestação. Dados representados em médias e respectivos erros padrão; $n=10 /$ grupo. ANOVA de duas vias, seguida do teste de Bonferroni: $* * p<0,01$

A Tabela 8 mostra os parâmetros do desempenho reprodutivo de ratas exposta ao fipronil durante a gestação. A ANOVA de uma via não mostrou diferenças significantes entre os grupos em nenhum dos parâmetros avaliados.

Tabela 7 - Peso gestacional semanal das ratas expostas ou não (controle) ao fipronil, do $6^{\circ}$ ao $20^{\circ}$ dia de gestação. Dados apresentados em médias e seus respectivos erros padrão ( $\mathrm{n}=$ número de animais)

\begin{tabular}{ccccc}
\hline \multirow{2}{*}{ Semana } & Controle & \multicolumn{3}{c}{ Fipronil $(\mathrm{mg} / \mathrm{Kg})$} \\
\cline { 3 - 5 } & $(\mathrm{n}=11)$ & $0,1(\mathrm{n}=11)$ & $1,0(\mathrm{n}=10)$ & $10,0(\mathrm{n}=13)$ \\
\hline $1^{\mathrm{a}}$ & $248,56 \pm 7,08$ & $244,72 \pm 6,04$ & $257,25 \pm 5,64$ & $232,28 \pm 4,92$ \\
$2^{\mathrm{a}}$ & $273,65 \pm 7,79$ & $266,87 \pm 6,52$ & $275,61 \pm 5,24$ & $261,68 \pm 2,62$ \\
$3^{\mathrm{a}}$ & $343,15 \pm 8,09$ & $334,91 \pm 9,39$ & $349,44 \pm 6,93$ & $340,16 \pm 8,81$ \\
\hline \multicolumn{2}{c}{ ANOVA duas vias: $\mathrm{p}>0,05$} & & &
\end{tabular}


Tabela 8 - Parâmetros do desempenho reprodutivo de ratas exposta ou não (controle) ao fipronil durante a gestação. Dados expressos em média e seus respectivos erros padrão ou em porcentagem ( $\mathrm{n}=$ número de animais)

\begin{tabular}{lcccc}
\hline & Controle & \multicolumn{3}{c}{ Fipronil $(\mathrm{mg} / \mathrm{Kg})$} \\
\cline { 3 - 5 } \multicolumn{1}{c}{ Parâmetro } & $(\mathrm{n}=11)$ & $0,1(\mathrm{n}=11)$ & $1,0(\mathrm{n}=10)$ & 10,0 \\
& & & & $22 \pm 0$ \\
& $22 \pm 0,69$ & $22 \pm 0,14$ & $22 \pm 0$ \\
\hline Tempo de gestação (dias) & $11 \pm 0,68$ & $10 \pm 0,89$ & $11 \pm 0,63$ & $11 \pm 042$ \\
Tamanho da ninhada & $11 \pm 0,61$ & $10 \pm 0,89$ & $11 \pm 0,50$ & $11 \pm 0,41$ \\
Número de filhotes vivos & 3,33 & 2,70 & 4,50 & 0,67 \\
Natimortos (\%) & & & &
\end{tabular}

ANOVA de uma via: $p>0,05$.

\section{Experimento 5.1.2: Efeito da administração de fipronil, durante a gestação, no comportamento maternal}

As ratas do Experimento 5.1.1 e suas respectivas ninhadas foram utilizadas nesse experimento de avaliação do comportamento maternal, como descrito no item 4.3.3. A avaliação desse comportamento foi realizada no quinto dia de lactação.

A Tabela 9 e a Figura 15 mostram os parâmetros do comportamento maternal das ratas expostas ao fipronil durante a gestação. Em relação aos parâmetros de latência para a busca do primeiro filhotes, latência para o comportamento do full maternal behavior (FMB), porcentagem de ratas que apresentaram o comportamento de FMB, e qualidade do novo ninho, não houve diferença significante entre os grupos. 
Em relação à latência para agrupar todos os filhotes, houve diferença significante entre os grupos $(F(3 / 28)=4,23, p<0,05)$ e 0 teste de Dunnett mostrou que as ratas do grupo de $10,0 \mathrm{mg} / \mathrm{Kg}$ recolheram seus filhotes em tempo menor $(p<0,05)$ do que as fêmeas do grupo controle. $O$ teste de Quiquadrado não mostrou diferença na porcentagem de fêmeas que agruparam ou não todos os filhotes.

A diferença significante foi observada também no tempo de limpeza nos filhote $(F(3 / 24)=3,63, p<0,05)$ e o teste de Dunnett mostrou que as fêmeas dos grupos de 1,0 e $10,0 \mathrm{mg} / \mathrm{Kg}$ passaram mais tempo lambendo sua cria (ambos com $p<0,05)$ do que as fêmeas do grupo controle.

Em relação ao parâmetro de auto-limpeza, houve diferença significante entre os grupos $(F(3 / 28)=4,46, p<0,05)$ e o teste de Dunnett mostrou que as fêmeas dos grupos de 0,1 e 1,0 mg/Kg apresentaram maior frequência de autolimpeza ( $p<0,01$ e $p<0,05$, respectivamente) do que os animais do grupo controle. 
Tabela 9 - Parâmetros do comportamento maternal das ratas expostas ou não (controle) ao fipronil, do $6^{\circ}$ ao $20^{\circ}$ dia de gestação. Dados expressos em média e seus respectivos erros padrão ou em porcentagem ( $\mathrm{n}$ = número de animais por grupo)

\begin{tabular}{|c|c|c|c|c|}
\hline \multirow{2}{*}{ Parâmetro } & \multirow{2}{*}{$\begin{array}{l}\text { Controle } \\
(\mathrm{n}=8)\end{array}$} & \multicolumn{3}{|c|}{ Fipronil (mg/Kg) } \\
\hline & & $0,1(n=9)$ & $1,0(n=8)$ & $10,0(n=8)$ \\
\hline $\begin{array}{l}\text { Latência para busca } \\
\text { do } 1^{\circ} \text { filhote }(\mathrm{s})^{\mathrm{a}}\end{array}$ & $21,8 \pm 5,3$ & $23,6 \pm 8,1$ & $22,4 \pm 3,7$ & $14 \pm 5,6$ \\
\hline $\begin{array}{l}\text { Latência para } \\
\text { agrupar todos os } \\
\text { filhotes (s) }\end{array}$ & $434,3 \pm 60,3$ & $409,2 \pm 66,3$ & $446,9 \pm 41,1$ & $212 \pm 29,4^{*}$ \\
\hline $\begin{array}{l}\text { Mães que agruparam } \\
\text { todos os filhotes }(\%)^{\text {b }}\end{array}$ & 88 & 45 & 100 & 63 \\
\hline $\begin{array}{l}\text { Tempo de limpeza no } \\
\text { filhote }(\mathrm{s})^{\mathrm{a}}\end{array}$ & $207,5 \pm 23,5$ & $252,3 \pm 22,9$ & $300,8 \pm 12,9 *$ & 297 16,9* \\
\hline $\begin{array}{l}\text { Frequência de auto- } \\
\text { limpeza }^{a}\end{array}$ & $2,9 \pm 0,2$ & $7,0 \pm 0,9 * *$ & $6,9 \pm 1,0^{*}$ & $6,0 \pm 1,1$ \\
\hline $\begin{array}{l}\text { Mães que fizeram } \\
\text { FMB em } 30 \text { min }(\%)^{b}\end{array}$ & 75 & 33 & 75 & 37,5 \\
\hline $\begin{array}{l}\text { Latência para o } \\
\text { FMB (s) }\end{array}$ & $1146 \pm 121,3$ & $1473 \pm 120,5$ & $1397 \pm 33,0$ & $1591 \pm 71,0$ \\
\hline $\begin{array}{l}\text { Escore de qualidade } \\
\text { do ninho }{ }^{a}\end{array}$ & $1,6 \pm 0,2$ & $0,6 \pm 0,3^{*}$ & $2,3 \pm 0,2$ & $2,0 \pm 0,3$ \\
\hline
\end{tabular}

$\mathrm{FMB}=$ full maternal behavior

${ }^{a}$ ANOVA de uma via seguida pelo teste de Dunnett: ${ }^{*} \mathrm{p}<0,01 ;{ }^{*} \mathrm{p}<0,05$.

${ }^{b}$ Análise de contingência com o teste de Qui-quadrado: $p>0,05$. 
Latência para busc a do $1^{\circ}$ filhote ${ }^{a}$

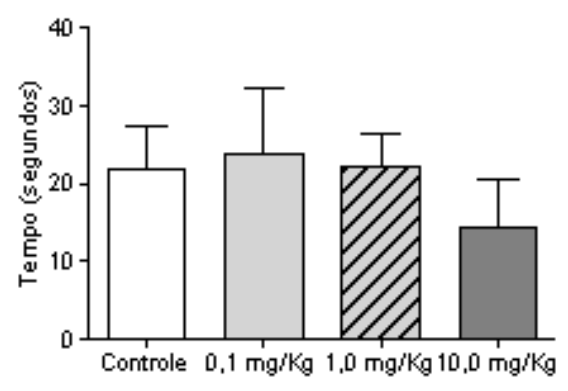

Número de mấes que buscaran todos os filhotes b
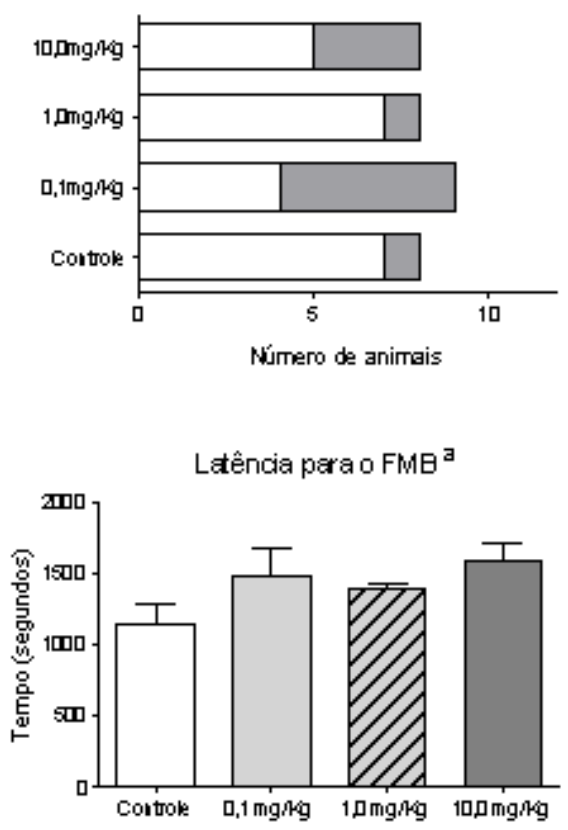

Tempo de limpeza do filhote ${ }^{a}$

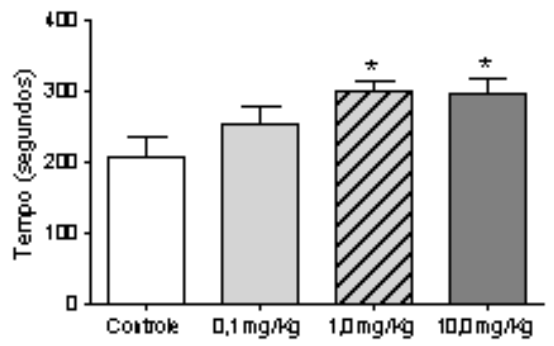

Latência para agrupar $100 \%$ da ninhada ${ }^{3}$

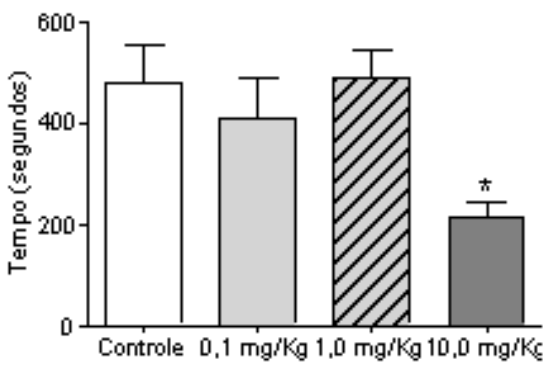

F requência de auto-limpeza ${ }^{a}$

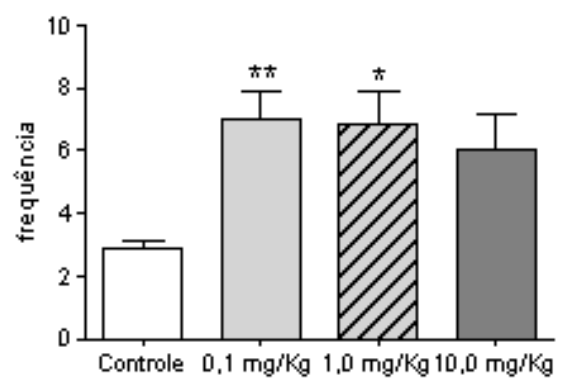

Número de mẫes que fizeran $\mathrm{FMB}^{\mathrm{b}}$

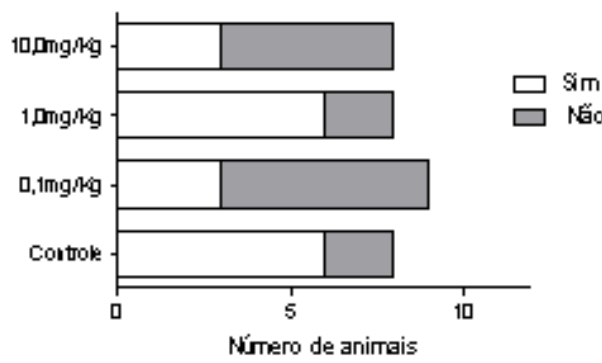

Qualidade do ninho ${ }^{a}$

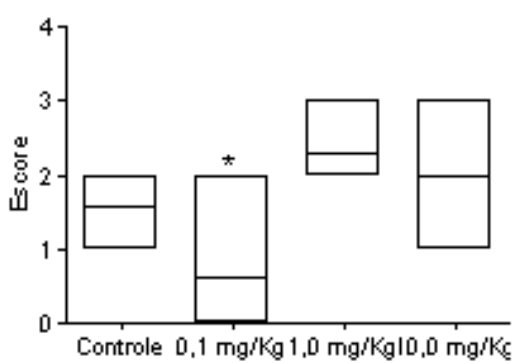

Figura 15: Parâmetros do comportamento maternal de ratas expostas ou não (controle) ao fipronil, do $6^{\circ}$ ao $20^{\circ}$ dia de gestação. ${ }^{a}$ ANOVA de uma via seguida pelo teste de Dunnett (médias e respectivos erros padrão): ${ }^{*} \mathrm{p} p<0,01 ;{ }^{*} \mathrm{p}<0,05 ;{ }^{\mathrm{b}}$ Teste de Qui-quadrado: $\mathrm{p}>0,05$. 


\subsection{PARTE 2 - Efeitos do fipronil na prole até o $35^{\circ}$ dia de vida}

Os experimentos dessa Parte estão relacionados aos estudos sobre o desenvolvimento físico e reflexológico da prole até o $35^{\circ}$ dia de vida, decorrente da exposição da mãe ao fipronil, no período do $6^{\circ}$ ao $20^{\circ}$ dia de gestação.

\section{Experimento 5.2.1: Efeito da administração de fipronil, durante a gestação, no desenvolvimento físico e reflexológico da prole de ratos}

Quarenta ratas virgens, Wistar, foram casaladas e quando diagnosticas prenhez (conforme descrito no item 4.3.1) foram tratadas com diferentes doses de fipronil $\left(0,1 ; 1,0\right.$ ou $10,0 \mathrm{mg} / \mathrm{Kg}$ ) ou com água (grupo controle) do $6^{\circ}$ ao $20^{\circ}$ dia de gestação.

No dia do nascimento foi realizada apenas a observação de natimortos e malformações grosseiras, sendo que nenhum grupo apresentou tais malformações. A partir do segundo dia pós-nascimento (DPN2), a ninhada foi padronizada para 8 filhotes (4 fêmeas e 4 machos, sempre que possível), e um casal foi escolhido ao acaso, e identificado com nanquim, para as observações dos parâmetros do desenvolvimento físico e reflexológico (item 4.3.4).

A Tabela 10 mostra o peso corporal dos filhotes durante a infância. A ANOVA de duas vias não mostrou diferenças significantes entre os grupos da prole masculina, nem em relação ao tratamento, nem em relação ao tempo de 
vida. Por outro lado, na prole feminina, a ANOVA de duas vias mostrou diferenças significantes entre os grupos em relação ao tempo de vida ( $F$ $(3 / 214)=98,68, p<0,001)$, mas não em relação ao tratamento e não houve interação entre os fatores. $O$ teste de Dunnett mostrou que as fêmeas, cujas mães estiveram expostas as doses de 1,0 e 10,0 mg/Kg apresentaram aumento significante de peso corporal no $35^{\circ}$ dias de vida $(p<0,05)$, quando comparadas com os animais do grupo controle (Figura 16).

Tabela 10 - Peso corporal (em gramas) dos filhotes (macho e fêmea) de ratas expostas ou não (controle) ao fipronil, do $6^{\circ}$ ao $20^{\circ}$ dia de gestação. Dados expressos em média e seus respectivos erros padrão ( $n=10$ animais/grupo)

\begin{tabular}{cccccc}
\hline \multirow{2}{*}{ Idade } & \multirow{2}{*}{ Sexo } & \multirow{2}{*}{ Controle } & \multicolumn{3}{c}{ Fipronil $(\mathrm{mg} / \mathrm{Kg})$} \\
\cline { 4 - 6 } & & & 0,1 & 1,0 & 10,0 \\
\hline \multirow{2}{*}{ DPN 2 } & Macho & $7,28 \pm 0,39$ & $7,24 \pm 0,52$ & $7,84 \pm 0,19$ & $7,06 \pm 0,38$ \\
& Fêmea & $7,03 \pm 0,35$ & $6,95 \pm 0,45$ & $7,51 \pm 0,18$ & $6,91 \pm 0,32$ \\
\multirow{2}{*}{ DPN 7 } & Macho & $15,93 \pm 0,84$ & $15,86 \pm 0,66$ & $16,22 \pm 0,44$ & $15,99 \pm 0,41$ \\
& Fêmea & $15,45 \pm 0,66$ & $15,25 \pm 0,62$ & $15,86 \pm 0,43$ & $15,38 \pm 0,53$ \\
DPN 14 & Macho & $29,85 \pm 1,35$ & $29,53 \pm 0,88$ & $30,00 \pm 0,80$ & $29,88 \pm 0,68$ \\
& Fêmea & $29,22 \pm 0,98$ & $29,01 \pm 0,83$ & $29,22 \pm 0,76$ & $28,68 \pm 0,71$ \\
DPN 21 & Macho & $47,95 \pm 1,68$ & $48,44 \pm 2,05$ & $48,38 \pm 1,70$ & $47,51 \pm 1,06$ \\
& Fêmea & $45,43 \pm 1,01$ & $46,07 \pm 1,85$ & $45,94 \pm 1,47$ & $45,16 \pm 0,79$ \\
DPN 28 & Macho & $83,52 \pm 2,64$ & $84,28 \pm 1,47$ & $83,60 \pm 1,94$ & $80,08 \pm 1,69$ \\
& Fêmea & $78,92 \pm 1,88$ & $77,54 \pm 2,03$ & $78,90 \pm 1,37$ & $75,13 \pm 1,36$ \\
DPN 35 & Macho & $128,23 \pm 5,15$ & $125,57 \pm 2,75$ & $126,76 \pm 2,80$ & $130,63 \pm 2,46$ \\
& Fêmea & $108,96 \pm 2,19$ & $111,27 \pm 2,33$ & $113,84 \pm 1,57 *$ & $113,98 \pm 1,32 *$ \\
\hline
\end{tabular}

$\mathrm{DPN}=$ dia pós-nascimento. ANOVA seguida pelo teste de Bonferroni: $* \mathrm{p}<0,05$ 


\section{Peso corporal da prole feminina}

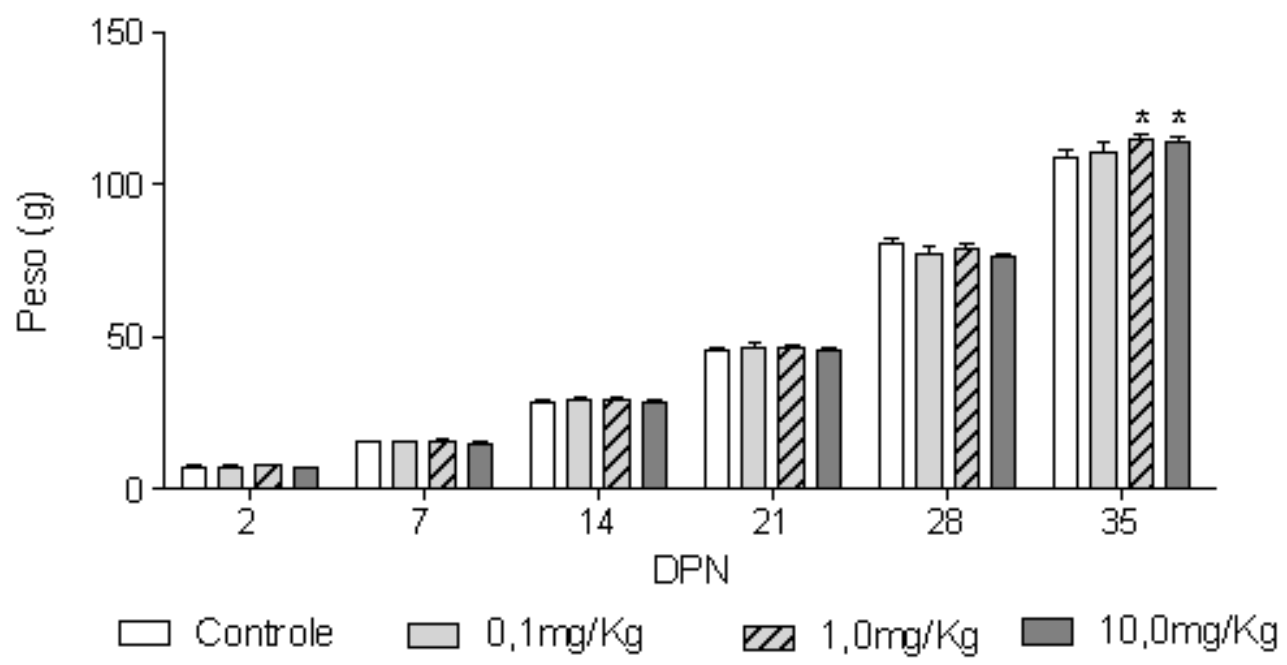

Figura 16: Peso corporal (em gramas) da prole feminina de ratas expostas ou não (controle) ao fipronil, do $6^{\circ}$ ao $20^{\circ}$ dia de gestação. Dados expressos em médias e erros padrão. DPN = dia pós-nascimento; $n=10$ animais por grupo. ANOVA de duas vias, seguida pelo teste de Bonferroni: ${ }^{*} p<0,05$.

A Tabela 11 mostra os parâmetros do desenvolvimento físico da prole feminina e masculina, cujas mães foram expostas ao fipronil do $6^{\circ}$ ao $20^{\circ}$ dia de gestação. Com relação à prole masculina, a ANOVA de uma via não indicou diferenças significantes entre os grupos em nenhum dos parâmetros, porém, na prole feminina, apenas o dia de andar adulto mostrou diferenças significantes $(F(3 / 39)=3,36, p<0,05)$ entre os grupos. O teste de Dunnett mostrou que as fêmeas do grupo de $1,0 \mathrm{mg} / \mathrm{Kg}$ apresentaram adiantamento significante para 0 aparecimento deste parâmetro ( $p<0,01)$ (Figura 17). 
Tabela 11 - Parâmetros do desenvolvimento físico da prole de ratas expostas ou não (controle) a diferentes doses de fipronil, do $6^{\circ}$ ao $20^{\circ}$ dia de gestação. Dados expressos em médias e seus respectivos erros padrão. ( $n=10$ animais/grupo)

\begin{tabular}{cccccc}
\hline \multirow{2}{*}{ Parâmetro } & \multirow{2}{*}{ Sexo } & Controle & \multicolumn{3}{c}{ Fipronil $(\mathrm{mg} / \mathrm{Kg})$} \\
\cline { 4 - 6 } & & & 0,1 & 1,0 & 10,0 \\
\hline \multirow{2}{*}{ Orelha } & Macho & $2,2 \pm 0,12$ & $2,4 \pm 0,14$ & $2,3 \pm 0,15$ & $2,3 \pm 0,17$ \\
& Fêmea & $2,2 \pm 0,12$ & $2,5 \pm 0,20$ & $2,2 \pm 0,13$ & $2,2 \pm 0,16$ \\
\multirow{2}{*}{ Pêlos } & Macho & $8,0 \pm 0,26$ & $8,4 \pm 0,14$ & $7,8 \pm 0,31$ & $7,8 \pm 0,29$ \\
& Fêmea & $8,0 \pm 0,26$ & $8,4 \pm 0,14$ & $8,1 \pm 0,30$ & $7,8 \pm 0,29$ \\
\multirow{2}{*}{ Dentes } & Macho & $10,1 \pm 0,33$ & $10,3 \pm 0,19$ & $10,2 \pm 0,19$ & $9,8 \pm 0,18$ \\
\multirow{2}{*}{ Olhos } & Fêmea & $9,7 \pm 0,34$ & $10,1 \pm 0,24$ & $10,3 \pm 0,20$ & $9,8 \pm 0,21$ \\
\multirow{2}{*}{ Andar } & Macho & $13,4 \pm 0,23$ & $12,8 \pm 0,28$ & $13,2 \pm 0,19$ & $13,3 \pm 0,13$ \\
adulto & Mêmea & $13,5 \pm 0,15$ & $13,0 \pm 0,31$ & $13,1 \pm 0,17$ & $13,2 \pm 0,18$ \\
Descida de testículo & $13,4 \pm 0,20$ & $12,8 \pm 0,12$ & $12,7 \pm 0,20$ & $12,9 \pm 0,07$ \\
Abertura vaginal & $34,4 \pm 0,22$ & $35,4 \pm 0,60$ & $35,2 \pm 0,50$ & $33,8 \pm 0,35$ \\
\hline
\end{tabular}

ANOVA seguida pelo teste de Dunnett: $* * p<0,01$

\section{Andar adulto}

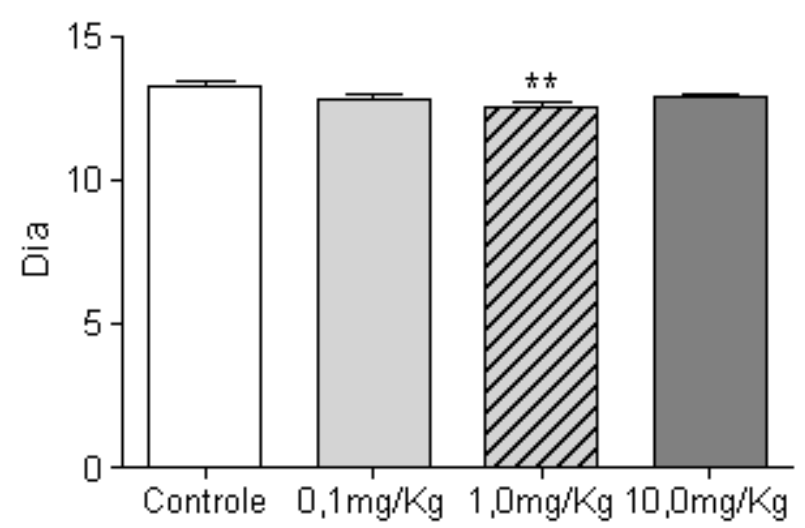

Figura 17: Dia de andar adulto da prole feminina de ratas expostas ou não (controle) ao fipronil, do $6^{\circ}$ ao $20^{\circ}$ dia de gestação. Dados expressos em médias e erros padrão $(n=10$ animais por grupo). ANOVA de uma via, seguida pelo teste de Dunnett: $* * p<0,01$ 
A Tabela 12 mostra os parâmetros do desenvolvimento reflexológicos da prole de ratas expostas ao fipronil durante a gestação. A ANOVA de uma via mostrou diferenças significantes entre os grupos apenas na geotaxia negativa, tanto da prole masculina $(F(3 / 40)=4,02, p<0,05)$, quanto da prole feminina $(F(3 / 39)=3,94, p<0,05) .0$ teste de Dunnett mostrou que os animais do grupo de $0,1 \mathrm{mg} / \mathrm{Kg}$, tanto machos $(p<0,01)$ quanto fêmeas $(p<0,05)$ apresentaram atraso significante no desenvolvimento desse reflexo quando comparados aos animais do grupo controle (Figura 18).

Tabela 12 - Parâmetros do desenvolvimento reflexológico (em dias) da prole de ratas expostas a diferentes doses de fipronil, do $6^{\circ}$ ao $20^{\circ}$ dia de gestação. Dados expressos em médias e seus respectivos erros padrão; $(n=11$ animais por grupo)

\begin{tabular}{lccccc}
\hline \multirow{2}{*}{ Parâmetro } & \multirow{2}{*}{ Sexo } & Controle & \multicolumn{3}{c}{ Fipronil $(\mathrm{mg} / \mathrm{Kg})$} \\
\cline { 4 - 6 } & & & 0,1 & 1,0 & 10,0 \\
\hline \multirow{2}{*}{ Pressão Palmar } & Macho & $4,6 \pm 0,15$ & $3,8 \pm 0,26$ & $3,9 \pm 0,21$ & $4,0 \pm 0,30$ \\
& Fêmea & $4,6 \pm 0,15$ & $3,8 \pm 0,26$ & $3,9 \pm 0,21$ & $3,9 \pm 0,31$ \\
\multirow{2}{*}{ Endireitamento } & Macho & $4,8 \pm 0,12$ & $4,8 \pm 0,12$ & $4,9 \pm 0,09$ & $4,7 \pm 0,14$ \\
\cline { 4 - 6 } Geotaxia & Fêmea & $4,8 \pm 0,12$ & $4,8 \pm 0,12$ & $4,9 \pm 0,09$ & $4,7 \pm 0,14$ \\
negativa & Macho & $5,5 \pm 0,16$ & $6,5 \pm 0,20 * *$ & $5,6 \pm 0,20$ & $5,6 \pm 0,24$ \\
& Fêmea & $5,8 \pm 0,12$ & $6,8 \pm 0,30 *$ & $5,7 \pm 0,24$ & $6,0 \pm 0,89$ \\
\hline
\end{tabular}

ANOVA seguida pelo teste de Dunnett: $* \mathrm{p}<0,05 ; * * \mathrm{p}<0,01$. 
Geotaxia - fêmea

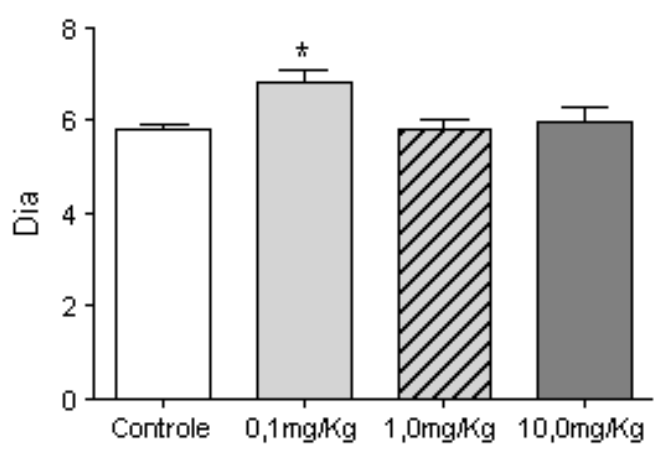

Geotaxia - macho

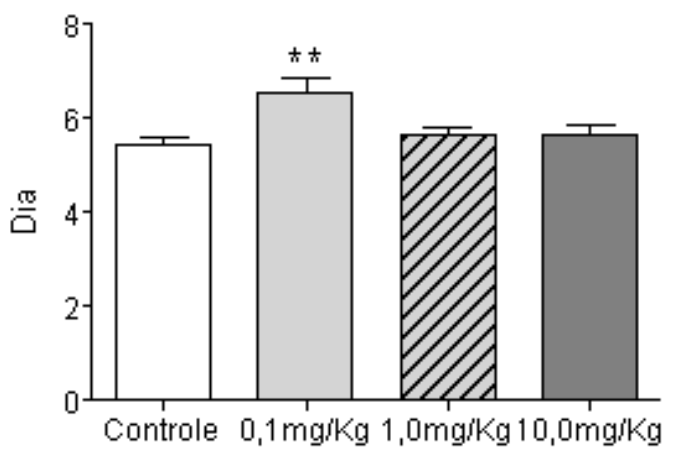

Figura 18: Geotaxia negativa (em dias) da prole feminina e masculina de ratas expostas ou não (controle) ao fipronil, do $6^{\circ}$ ao $20^{\circ}$ dia de gestação. Dados expressos em médias e seus respectivos erros padrão; $n=11$ animais por grupo. ANOVA de uma via, seguida pelo teste de Dunnett: ${ }^{*} p<0,05$ e $* * p<0,01$.

Experimento 5.2.2: Efeito da administração de fipronil, durante a gestação, na atividade geral em campo aberto da prole de ratos na infância

Os filhotes utilizados no experimento anterior foram avaliados por sete dias consecutivos (do DPN15 ao DPN21), por 3 minutos, quanto à atividade geral em campo aberto, conforme descrito no item 4.3.5.

As Tabelas 13 - 16 mostram os parâmetros avaliados no campo aberto da prole de ratas expostas ao fipronil durante a gestação; a Figura 19 ilustra o perfil locomotor da prole durante os sete dias de teste, a Figura 20 ilustra os demais parâmetros da atividade geral da prole masculina e a Figura 21 ilustra os demais parâmetros da atividade geral da prole feminina. 
Na frequência de locomoção da prole masculina, a ANOVA de duas vias mostrou diferenças significantes entre os grupos quanto ao tratamento $(F(3 / 205)=19,15 ; p<0,001)$ e aos dias de teste $(F(3 / 205)=4,59, p<0,001)$, sem interação entre os fatores. O teste de Bonferroni mostrou que os animais do grupo de $0,1 \mathrm{mg} / \mathrm{Kg}$ apresentaram maior locomotora nos DPN16, DPN17 e DPN21 ( $p<0,05, p<0,05$ e $p<0,01$, respectivamente), enquanto os animais do grupo de $1,0 \mathrm{mg} / \mathrm{Kg}$ apresentaram maior locomoção nos DPN16, DPN20 e DPN21 ( $p<0,01, p<0,05$ e $p<0,001$, respectivamente), quando comparados aos animais do grupo controle. Na prole feminina, a ANOVA de duas vias mostrou diferenças significantes entre os grupos quanto ao tratamento $(F(3 / 218)=$ $39,30, p<0,001)$ e aos dias de teste $(F(3 / 218)=5,83, p<0,001)$, havendo interação entre os fatores $(F(3 / 218)=4,83, p<0,001)$. 0 teste de Bonferroni mostrou aumento significante da locomoção de fêmeas do grupo $0,1 \mathrm{mg} / \mathrm{Kg}$ nos dias DPN17, DPN18 e DPN21 ( $<<0,001)$, enquanto nas fêmeas do grupo de $1,0 \mathrm{mg} / \mathrm{Kg}$, nos dias DPN15 ao DPN18 $(\mathrm{p}<0,05$ a $\mathrm{p}<0,001)$ e no DPN21 $(p<0,01)$, em relação ao grupo controle. 
Parte 2

Tabela 13 - Frequência de locomoção no campo aberto, do DPN15 ao DPN21, da prole de ratas expostas ou não (controle) ao fipronil, do $6^{\circ}$ ao $20^{\circ}$ dia de gestação. Dados expressos em médias e respectivos erros padrão ( $n=$ número de animais)

\begin{tabular}{|c|c|c|c|c|c|}
\hline \multirow{2}{*}{ DPN } & \multirow{2}{*}{ Sexo } & \multirow{2}{*}{$\begin{array}{l}\text { Controle } \\
(n=9)\end{array}$} & \multicolumn{3}{|c|}{ Fipronil (mg/Kg) } \\
\hline & & & $0,1(n=10)$ & $1,0(n=9)$ & $10,0(n=10)$ \\
\hline \multirow{2}{*}{15} & $M$ & $8,4 \pm 3,68$ & $22,4 \pm 4,59$ & $12,5 \pm 3,18$ & $13,0 \pm 3,54$ \\
\hline & $\mathrm{F}$ & $8,2 \pm 2,37$ & $16,4 \pm 2,61$ & $24,13 \pm 2,13^{* * *}$ & $15,3 \pm 2,82$ \\
\hline \multirow{2}{*}{16} & M & $5,8 \pm 1,40$ & $24,3 \pm 4,38^{*}$ & $26,3 \pm 4,81 * *$ & $9,8 \pm 2,16$ \\
\hline & $F$ & $8,7 \pm 2,11$ & $8,9 \pm 1,34$ & $32,38 \pm 2,17 * * *$ & $10,1 \pm 1,80$ \\
\hline \multirow{2}{*}{17} & M & $10,5 \pm 2,86$ & $27,6 \pm 5,02 *$ & $23,3 \pm 4,90$ & $16,8 \pm 4,56$ \\
\hline & $\mathrm{F}$ & $10,4 \pm 1,45$ & $32,0 \pm 2,10 * * *$ & $23,6 \pm 1,99 * *$ & $11,4 \pm 1,18$ \\
\hline \multirow{2}{*}{18} & M & $11,8 \pm 2,52$ & $23,5 \pm 3,33$ & $24,6 \pm 3,88$ & $17,1 \pm 4,40$ \\
\hline & $\mathrm{F}$ & $10,8 \pm 1,14$ & $27,9 \pm 2,93 * * *$ & $21,56 \pm 2,57^{*}$ & $15,1 \pm 2,82$ \\
\hline \multirow{2}{*}{19} & M & $15,6 \pm 3,80$ & $26,3 \pm 4,82$ & $23,3 \pm 3,35$ & $16,8 \pm 4,83$ \\
\hline & $\mathrm{F}$ & $13,0 \pm 1,87$ & $32,3 \pm 3,79$ & $17,25 \pm 1,82$ & $10,3 \pm 3,35$ \\
\hline \multirow{2}{*}{20} & M & $11,0 \pm 2,66$ & $19,4 \pm 4,30$ & $28,4 \pm 4,82 *$ & $24,9 \pm 6,83$ \\
\hline & $\mathrm{F}$ & $12,0 \pm 2,66$ & $15,6 \pm 3,63$ & $11,5 \pm 1,99$ & $13,0 \pm 2,16$ \\
\hline \multirow{2}{*}{21} & M & $14,3 \pm 2,28$ & $34,6 \pm 5,02 * *$ & $43,9 \pm 5,36 * * *$ & $21,8 \pm 5,29$ \\
\hline & $F$ & $14,4 \pm 2,87$ & $32,5 \pm 3,71^{* * *}$ & $27,38 \pm 1,59 * *$ & $16,6 \pm 3,28$ \\
\hline
\end{tabular}

DPN = dia pós-nascimento; $M=$ machos; $F=$ fêmeas.

ANOVA de duas vias, seguida pelo teste de Bonferroni: ${ }^{* * *} \mathrm{p}<0,001 ;{ }^{* *} \mathrm{p}<0,01 ;{ }^{*} \mathrm{p}<0,05$

Na frequência de levantar da prole masculina de ratas expostas ao fipronil (Tabela 14), a ANOVA de duas vias mostrou diferença significante entre os grupos quanto ao tratamento $(F(3 / 235)=5,09, p<0,01)$ e aos dias de teste $(F$ $(3 / 235)=2,32, p<0,05$, com interação entre os fatores $(F(3 / 235)=1,87$, $\mathrm{p}<0,05)$. O teste de Bonferroni mostrou que os animais do grupo $1,0 \mathrm{mg} / \mathrm{Kg}$ levantaram mais vezes do que os animais do grupo controle nos DPN16 e DPN21 ( $p<0,01$ e $p<0,05$, respectivamente). Na prole feminina, a ANOVA de 
duas vias mostrou diferenças significantes entre os grupo quanto ao tratamento $(F(3 / 233)=9,66, p<0,001)$, mas não quanto aos dias de teste, não havendo interação entre os fatores. $O$ teste de Bonferroni mostrou que as fêmeas do grupo de $1,0 \mathrm{mg} / \mathrm{Kg}$ levantaram mais vezes do que os animais do grupo controle nos DPN16, DPN17 e DPN21 $(p<0,01)$.

Em relação ao parâmetro de frequência de auto-limpeza, sobre a prole masculina, a ANOVA de duas vias não mostrou diferença significante ente os fatores, ao contrário da prole feminina, onde houve diferença apenas no fator tratamento $(F(3 / 232)=3,30, p<0,05)$ e o teste de Bonferroni mostrou que as fêmeas do grupo de $10,0 \mathrm{mg} / \mathrm{Kg}$ apresentaram maior freqüências de autolimpeza no dia DPN18 $(p<0,05)($ Tabela 15). 
Tabela 14 - Frequência de levantar no campo aberto, do DPN15 ao DPN21, da prole de ratas expostas ou não (controle) ao fipronil, do $6^{\circ}$ ao $20^{\circ}$ dia de gestação. Dados expressos em médias e respectivos erros padrão ( $\mathrm{n}$ = número de animais)

\begin{tabular}{|c|c|c|c|c|c|}
\hline \multirow{2}{*}{ DPN } & \multirow{2}{*}{ Sexo } & \multirow{2}{*}{$\begin{array}{l}\text { Controle } \\
(n=9)\end{array}$} & \multicolumn{3}{|c|}{ Fipronil (mg/Kg) } \\
\hline & & & $0,1(n=11)$ & $1,0(n=9)$ & $10,0(n=11)$ \\
\hline \multirow{2}{*}{15} & $M$ & $0,5 \pm 0,50$ & $3,6 \pm 0,72$ & $4,0 \pm 1,30$ & $3,3 \pm 1,27$ \\
\hline & $\mathrm{F}$ & $4,5 \pm 0,99$ & $2,0 \pm 0,28$ & $5,9 \pm 0,97$ & $3,1 \pm 0,92$ \\
\hline \multirow{2}{*}{16} & M & $2,5 \pm 0,96$ & $4,8 \pm 0,74$ & $8,3 \pm 1,31^{* *}$ & $3,5 \pm 1,05$ \\
\hline & $\mathrm{F}$ & $1,4 \pm 0,62$ & $3,5 \pm 0,65$ & $5,8 \pm 0,92 * *$ & $2,2 \pm 0,55$ \\
\hline \multirow{2}{*}{17} & $M$ & $2,5 \pm 0,91$ & $6,6 \pm 1,74$ & $4,1 \pm 0,68$ & $5,5 \pm 1,71$ \\
\hline & $\mathrm{F}$ & $1,9 \pm 0,63$ & $3,3 \pm 0,72$ & $6,4 \pm 0,99 * *$ & $2,9 \pm 0,85$ \\
\hline \multirow{2}{*}{18} & $M$ & $4,1 \pm 1,60$ & $3,6 \pm 1,34$ & $3,3 \pm 0,33$ & $3,3 \pm 0,73$ \\
\hline & $\mathrm{F}$ & $2,2 \pm 0,92$ & $2,2 \pm 0,47$ & $1,9 \pm 0,42$ & $3,6 \pm 0,82$ \\
\hline \multirow{2}{*}{19} & $M$ & $4,0 \pm 1,65$ & $2,3 \pm 0,78$ & $3,6 \pm 0,78$ & $3,3 \pm 0,70$ \\
\hline & $\mathrm{F}$ & $1,8 \pm 0,43$ & $3,8 \pm 0,95$ & $3,8 \pm 0,71$ & $3,5 \pm 1,19$ \\
\hline \multirow{2}{*}{20} & $M$ & $1,6 \pm 0,82$ & $1,7 \pm 0,37$ & $3,9 \pm 0,99$ & $3,5 \pm 1,01$ \\
\hline & $\mathrm{F}$ & $3,0 \pm 0,99$ & $2,4 \pm 0,80$ & $2,8 \pm 0,70$ & $3,9 \pm 1,01$ \\
\hline \multirow{2}{*}{21} & M & $3,0 \pm 1,03$ & $3,6 \pm 1,20$ & $7,7 \pm 1,37 *$ & $1,6 \pm 0,61$ \\
\hline & $\mathrm{F}$ & $2,3 \pm 0,88$ & $3,8 \pm 0,52$ & $6,8 \pm 0,94 * *$ & $3,0 \pm 0,82$ \\
\hline
\end{tabular}

DPN = Dia pós-nascimento; $M=$ machos; $F=$ fêmeas.

ANOVA de duas vidas, seguida pelo teste de Bonferroni: ${ }^{* *} \mathrm{p}<0,01 ;{ }^{*} \mathrm{p}<0,05$ 
Tabela 15 - Frequência de auto-limpeza no campo aberto, do DPN15 ao DPN21, da prole de ratas expostas ou não (controle) ao fipronil, do $6^{\circ}$ ao $20^{\circ}$ dia de gestação. Dados em médias e respectivos erros padrão ( $n=$ número de animais)

\begin{tabular}{|c|c|c|c|c|c|}
\hline \multirow{2}{*}{ DPN } & \multirow{2}{*}{ Sexo } & \multirow{2}{*}{$\begin{array}{l}\text { Controle } \\
(n=9)\end{array}$} & \multicolumn{3}{|c|}{ Fipronil (mg/Kg) } \\
\hline & & & $0,1(n=10)$ & $1,0(n=9)$ & $10,0(n=10)$ \\
\hline \multirow[t]{2}{*}{15} & $M$ & $1,6 \pm 0,29$ & $1,6 \pm 0,31$ & $2,1 \pm 0,26$ & $1,7 \pm 0,26$ \\
\hline & $\mathrm{F}$ & $1,4 \pm 0,31$ & $2,1 \pm 0,38$ & $1,6 \pm 0,18$ & $1,9 \pm 0,28$ \\
\hline \multirow[t]{2}{*}{16} & $M$ & $1,3 \pm 0,24$ & $2,4 \pm 0,43$ & $2,0 \pm 0,37$ & $1,8 \pm 0,36$ \\
\hline & $\mathrm{F}$ & $1,6 \pm 0,38$ & $1,8 \pm 0,39$ & $1,8 \pm 0,22$ & $2,0 \pm 0,26$ \\
\hline \multirow[t]{2}{*}{17} & $M$ & $2,2 \pm 0,43$ & $2,1 \pm 0,40$ & $1,9 \pm 0,31$ & $2,8 \pm 0,47$ \\
\hline & $F$ & $2,0 \pm 0,33$ & $2,4 \pm 0,48$ & $2,1 \pm 0,35$ & $1,3 \pm 0,15$ \\
\hline \multirow[t]{2}{*}{18} & $M$ & $2,5 \pm 0,44$ & $2,3 \pm 0,37$ & $2,0 \pm 0,24$ & $1,8 \pm 0,36$ \\
\hline & $\mathrm{F}$ & $2,8 \pm 0,35$ & $1,8 \pm 0,39$ & $1,9 \pm 0,39$ & $1,2 \pm 0,36^{*}$ \\
\hline \multirow[t]{2}{*}{19} & M & $2,1 \pm 0,39$ & $2,2 \pm 0,39$ & $1,9 \pm 0,35$ & $1,7 \pm 0,37$ \\
\hline & $F$ & $1,7 \pm 0,29$ & $2,4 \pm 0,22$ & $1,8 \pm 0,30$ & $1,0 \pm 0,39$ \\
\hline \multirow[t]{2}{*}{20} & $M$ & $2,6 \pm 0,35$ & $1,5 \pm 0,27$ & $1,6 \pm 0,29$ & $2,3 \pm 0,34$ \\
\hline & $\mathrm{F}$ & $2,0 \pm 0,33$ & $1,45 \pm 0,32$ & $1,9 \pm 0,35$ & $1,8 \pm 0,26$ \\
\hline \multirow[t]{2}{*}{21} & $M$ & $2,4 \pm 0,34$ & $1,6 \pm 0,22$ & $1,8 \pm 0,40$ & $2,2 \pm 0,53$ \\
\hline & $\mathrm{F}$ & $1,7 \pm 0,33$ & $1,7 \pm 0,26$ & $1,8 \pm 0,36$ & $1,3 \pm 0,37$ \\
\hline
\end{tabular}

DPN = Dia pós-nascimento; $M=$ machos; $F=$ fêmeas.

ANOVA de duas vias, seguida pelo teste de Bonferroni: ${ }^{*} p<0,05$

Em relação ao tempo de imobilidade, a ANOVA de duas vias mostrou diferença significante apenas no fator tratamento, tanto sobre a prole masculina $(F(3 / 223)=3,12, p<0,05)$, quanto sobre a prole feminina $(F$ $(3 / 218)=3,17, p<0,05)$, sem interação entre os fatores. $O$ teste de Bonferroni mostrou diferença significante apenas na prole masculina, onde os animais do grupo de 0,1 e $1,0 \mathrm{mg} / \mathrm{Kg}$ apresentaram diminuição no tempo de imobilidade 
no dia DPN16 (ambos com $\mathrm{p}<0,01$ ) quando comparados aos animais do grupo controle (Tabela 16).

Tabela 16 - Tempo de imobilidade em campo aberto, do DPN15 ao DPN21, da prole de ratas expostas ou não (controle) ao fipronil, do $6^{\circ}$ ao $20^{\circ}$ dia de gestação. Dados expressos em médias e respectivos erros padrão ( $\mathrm{n}=$ número de animais)

\begin{tabular}{cccccc}
\hline \multirow{2}{*}{ DPN } & Sexo & $\begin{array}{c}\text { Controle } \\
(\mathrm{n}=9)\end{array}$ & \multicolumn{3}{c}{ Fipronil $(\mathrm{mg} / \mathrm{Kg})$} \\
\cline { 4 - 6 } & & & $0,1(\mathrm{n}=10)$ & $1,0(\mathrm{n}=9)$ & $10,0(\mathrm{n}=10)$ \\
\hline 15 & $\mathrm{M}$ & $2,3 \pm 0,39$ & $2,0 \pm 0,26$ & $2,2 \pm 0,36$ & $2,4 \pm 0,34$ \\
& $\mathrm{~F}$ & $2,8 \pm 0,49$ & $2,3 \pm 0,47$ & $1,8 \pm 0,41$ & $2,3 \pm 0,39$ \\
16 & $\mathrm{M}$ & $3,1 \pm 0,35$ & $1,4 \pm 0,22^{* *}$ & $1,4 \pm 0,24 * *$ & $2,7 \pm 0,37$ \\
& $\mathrm{~F}$ & $2,7 \pm 0,39$ & $2,1 \pm 0,35$ & $1,5 \pm 0,27$ & $2,6 \pm 0,34$ \\
17 & $\mathrm{M}$ & $2,0 \pm 0,38$ & $1,6 \pm 0,23$ & $1,3 \pm 0,24$ & $2,1 \pm 0,28$ \\
& $\mathrm{~F}$ & $2,5 \pm 0,46$ & $1,9 \pm 0,28$ & $1,9 \pm 0,52$ & $2,8 \pm 0,39$ \\
18 & $\mathrm{M}$ & $2,1 \pm 0,40$ & $1,2 \pm 0,21$ & $1,4 \pm 0,24$ & $2,2 \pm 0,33$ \\
& $\mathrm{~F}$ & $2,0 \pm 0,33$ & $2,2 \pm 0,36$ & $2,1 \pm 0,58$ & $2,5 \pm 0,45$ \\
19 & $\mathrm{M}$ & $2,1 \pm 0,40$ & $2,5 \pm 0,34$ & $1,7 \pm 0,29$ & $2,2 \pm 0,47$ \\
& $\mathrm{~F}$ & $3,1 \pm 0,35$ & $1,8 \pm 0,25$ & $2,3 \pm 0,41$ & $2,8 \pm 0,47$ \\
20 & $M$ & $1,9 \pm 0,24$ & $1,9 \pm 0,37$ & $2,3 \pm 0,39$ & $1,8 \pm 0,35$ \\
& $F$ & $2,4 \pm 0,49$ & $2,6 \pm 0,53$ & $3,8 \pm 0,56$ & $2,8 \pm 0,49$ \\
21 & $M$ & $1,6 \pm 0,26$ & $1,3 \pm 0,22$ & $2,1 \pm 0,39$ & $1,4 \pm 0,16$ \\
& $F$ & $2,0 \pm 0,20$ & $1,5 \pm 0,17$ & $1,9 \pm 0,44$ & $2,6 \pm 0,45$ \\
\hline
\end{tabular}

DPN = Dia pós-nascimento; $M=$ machos; $F$ = fêmeas.

ANOVA de duas vias, seguido pelo teste de Bonferroni: $* * p<0,01$ 

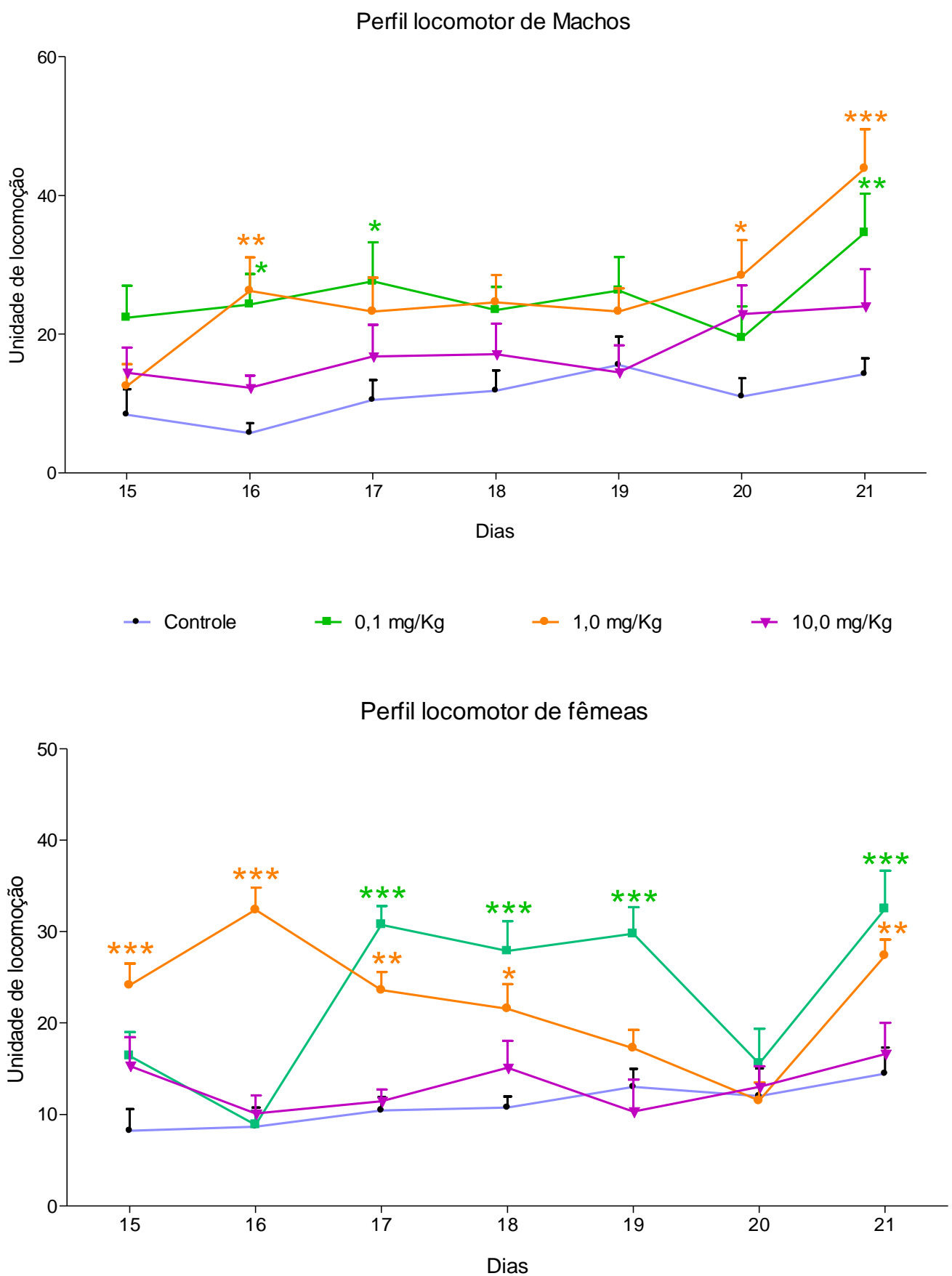

Figura 19: Perfil locomotor observado em campo aberto, do DPN15 ao DPN21, da prole masculina e feminina, de ratas expostas ou não (controle) ao fipronil, do $6^{\circ}$ ao $20^{\circ}$ dia de gestação. Dados expressos em médias e respectivos erros padrão. ANOVA de duas vias seguida pelo teste de Bonferroni: $* * * p<0,001 ; * * p<0,01 ; * p<0,05$. 
Imobilidade

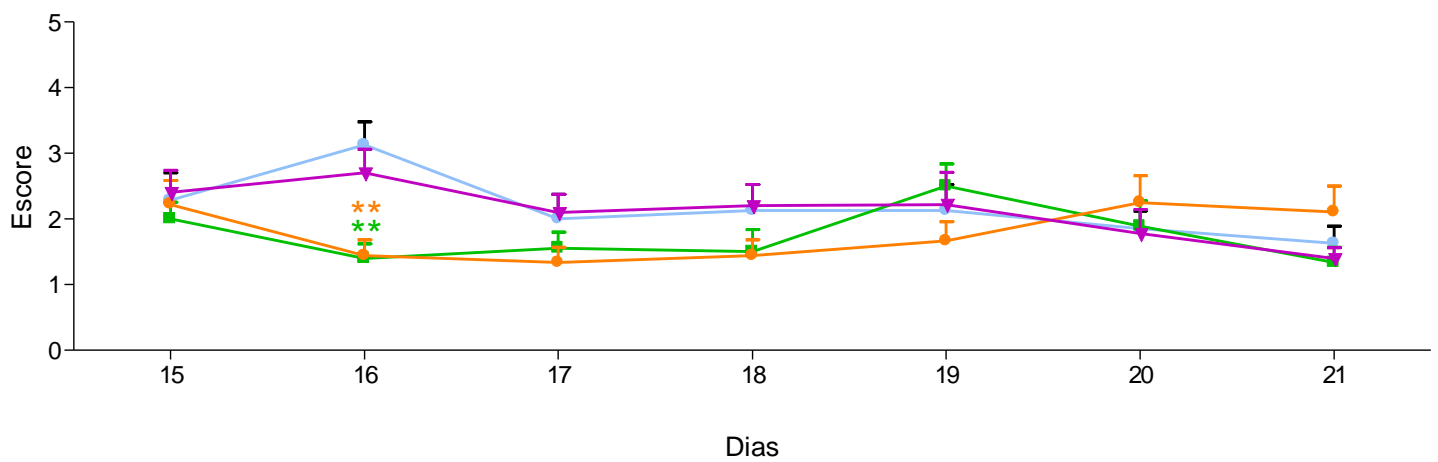

Levantar

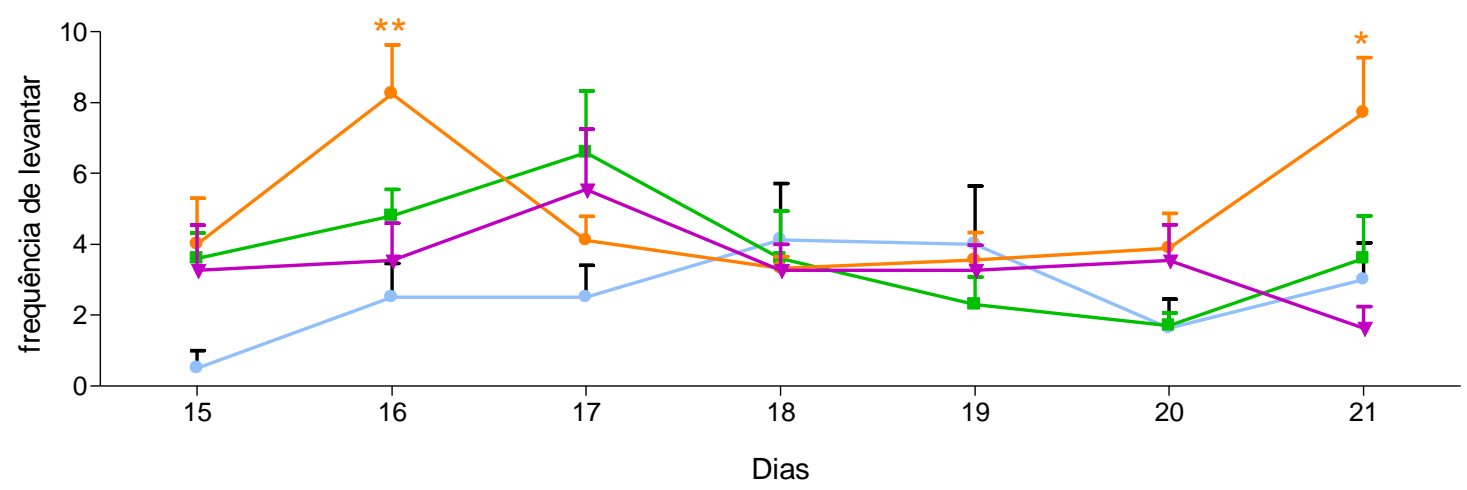

Auto-limpeza

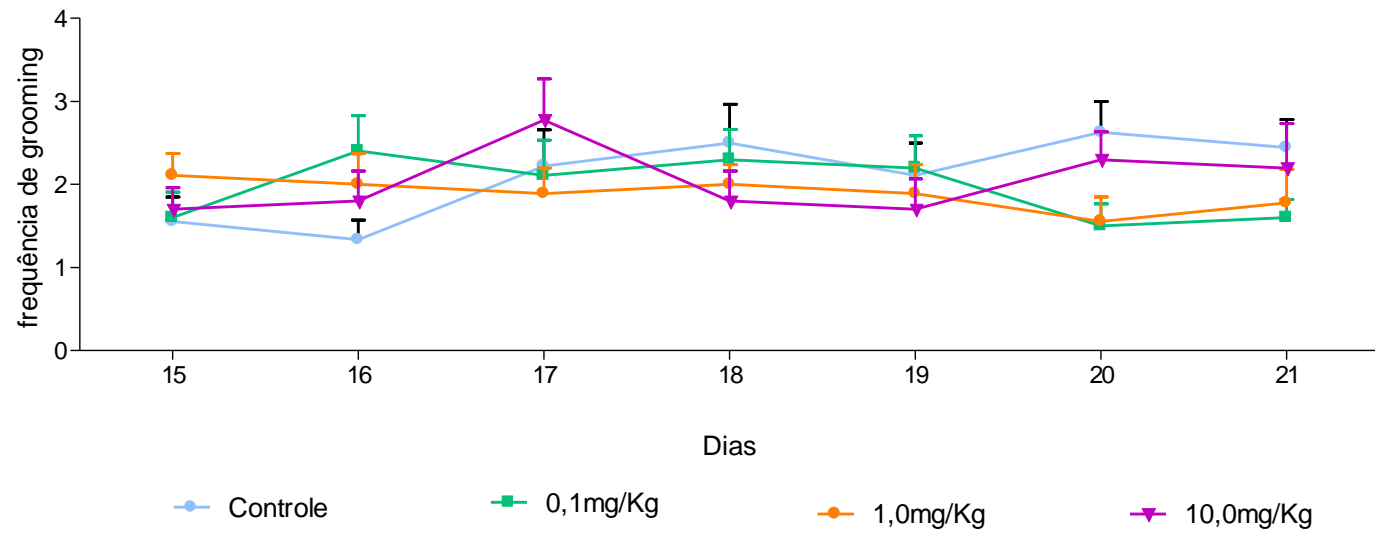

Figura 20: Perfil dos parâmetros da atividade geral em campo aberto, por 7 dias consecutivos, da prole masculina de ratas expostas ou não (controle) ao fipronil, do $6^{\circ}$ ao $20^{\circ}$ dia de gestação. Dados expressos em médias e respectivos erros padrão. ANOVA de duas vias seguido pelo teste de Bonferroni: ${ }^{* *} p<0,01 ; * p<0,05$. 

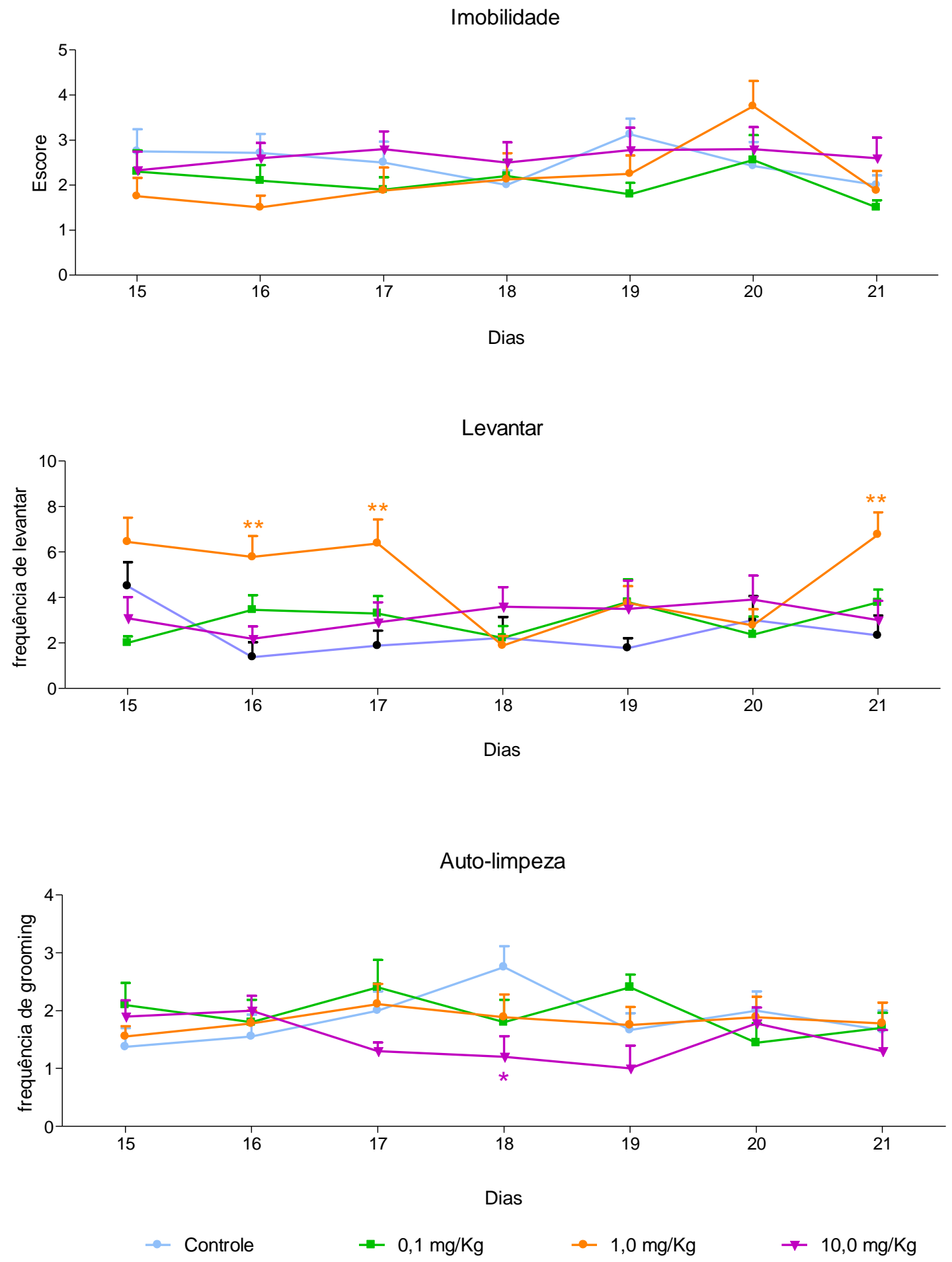

Figura 21: Perfil dos parâmetros da atividade geral em campo aberto, por 7 dias consecutivos, da prole feminina de ratas expostas ou não (controle) ao fipronil, do $6^{\circ}$ ao $20^{\circ}$ dia de gestação. Dados expressos em médias e respectivos erros padrão. ANOVA de duas vias seguido pelo teste de Bonferroni: ${ }^{* *} p<0,01 ;{ }^{*} p<0,05$. 


\subsection{Parte 3 - Efeitos do fipronil na prole adulta}

Os experimentos dessa Parte estão relacionados às investigações de alterações na idade adulta da prole, decorrente da exposição de sua progenitora ao fipronil, no período do $6^{\circ}$ ao $20^{\circ}$ dia de gestação.

\section{Experimento 5.3.1: Efeitos da administração de fipronil, durante a gestação, na resposta comportamental em campo aberto, labirinto em cruz elevado e interação social da prole na idade adulta}

Os animais dos experimentos anteriores, quando atingiram a idade de 75 dias de vida, foram avaliados quanto à resposta comportamental nos testes de campo aberto, labirinto em cruz elevado e interação social, conforme descrito nos itens 4.3.5, 4.3.6 e 4.3.7, respectivamente.

A Tabela 17 e a Figura 22 mostram os parâmetros avaliados no teste de campo aberto da prole na idade adulta, no DPN75, por 5 min.

Em relação à atividade locomotora e ao tempo de imobilidade, a ANOVA de duas vias não mostrou diferença significante entre os grupos, nem na prole masculina ou na prole feminina. Em relação à frequência de levantar, a ANOVA de duas vias mostrou diferenças quanto ao tratamento $(F(3 / 61)=8,17$, $p<0,001)$, ao sexo $(F(3 / 61)=68,44, p<0,001)$ e houve interação entre os fatores $(F(3 / 61)=5,37, p<0,01)$. O teste de Bonferroni mostrou que apenas as fêmeas, de todos os grupos experimentais apresentaram diferenças 
significantes quando comparadas ao grupo controle $(0,1 \mathrm{mg} / \mathrm{Kg}-\mathrm{p}<0,001 ; 1,0$ $\mathrm{mg} / \mathrm{Kg}-\mathrm{p}<0,05 ;$ e 10,0 mg/Kg - $\mathrm{p}<0,05)$.

Em relação a frequência de auto-limpeza, a ANOVA de uma via mostrou diferença significante entre os grupos, tanto na prole masculina $(F(3 / 34)=$ $3,57, p<0,05)$, quanto na prole feminina $(F(3 / 34)=1,07, p<0,05)$ e o teste de Dunnett mostrou que, na prole masculina, houve diminuição na frequência de auto-limpeza dos animais do grupo de 1,0 e 10,0 mg/Kg ( $p<0,05$ e $p<0,01$, respectivamente) e, na prole feminina, houve diminuição na frequência de auto-limpeza dos animais do grupo de 0,1 e 10,0 mg/Kg (ambos com p<0,05), em relação ao grupo controle.

Tabela 17 - Parâmetros da atividade geral em campo aberto, na prole adulta de ratas expostas ou não (controle) ao fipronil, do $6^{\circ}$ ao $20^{\circ}$ dia de gestação. Dados expressos em médias e respectivos erros padrão ( $n=$ número de animais; $M=$ machos; $F=$ fêmeas)

\begin{tabular}{|c|c|c|c|c|c|}
\hline \multirow{2}{*}{ Parâmetro } & \multirow{2}{*}{ Sexo } & \multirow{2}{*}{$\begin{array}{c}\text { Controle } \\
(n=9)\end{array}$} & \multicolumn{3}{|c|}{ Fipronil (mg/Kg) } \\
\hline & & & $0,1(n=9)$ & $1,0(n=9)$ & $10,0(n=10)$ \\
\hline \multirow[t]{2}{*}{ Locomoção $^{\mathrm{a}}$} & $M$ & $108,5 \pm 9,49$ & $105,1 \pm 7,51$ & $114,6 \pm 4,19$ & $112,8 \pm 7,36$ \\
\hline & $F$ & $127,0 \pm 10,91$ & $146,8 \pm 8,59$ & $153,1 \pm 11,82$ & $143,8 \pm 8,77$ \\
\hline \multirow[t]{2}{*}{ Levantar $^{\mathrm{a}}$} & M & $21,8 \pm 1,75$ & $19,2 \pm 2,49$ & $17,9 \pm 1,97$ & $26,0 \pm 2,86$ \\
\hline & $\mathrm{F}$ & $50,0 \pm 3,09$ & $24,9 \pm 3,29 * * *$ & $39,4 \pm 3,92 *$ & $39,8 \pm 3,02 *$ \\
\hline \multirow[t]{2}{*}{ Auto-limpezab } & M & $1,9 \pm 0,39$ & $1,4 \pm 0,34$ & $0,9 \pm 0,26^{*}$ & $0,7 \pm 0,32 * *$ \\
\hline & $\mathrm{F}$ & $1,1 \pm 0,28$ & $0,4 \pm 0,17^{*}$ & $0,4 \pm 0,18$ & $0,4 \pm 0,16 *$ \\
\hline \multirow[t]{2}{*}{ Imobilidade $^{a}$} & $M$ & $1,4 \pm 1,00$ & $3,1 \pm 1,08$ & $2,4 \pm 0,79$ & $1,1 \pm 0,62$ \\
\hline & $F$ & $0,6 \pm 0,47$ & $1,8 \pm 0,73$ & $0,8 \pm 0,50$ & $2,4 \pm 0,84$ \\
\hline
\end{tabular}

${ }^{a}$ ANOVA de duas vias seguido pelo teste de Bonferroni: ${ }^{* * *} \mathrm{p}<0,001 ;{ }^{*} \mathrm{p}<0,05$

${ }^{b}$ ANOVA de uma via seguido pelo teste de Dunnett: ${ }^{*} \mathrm{p}<0,01 ;{ }^{*} \mathrm{p}<0,05$ 

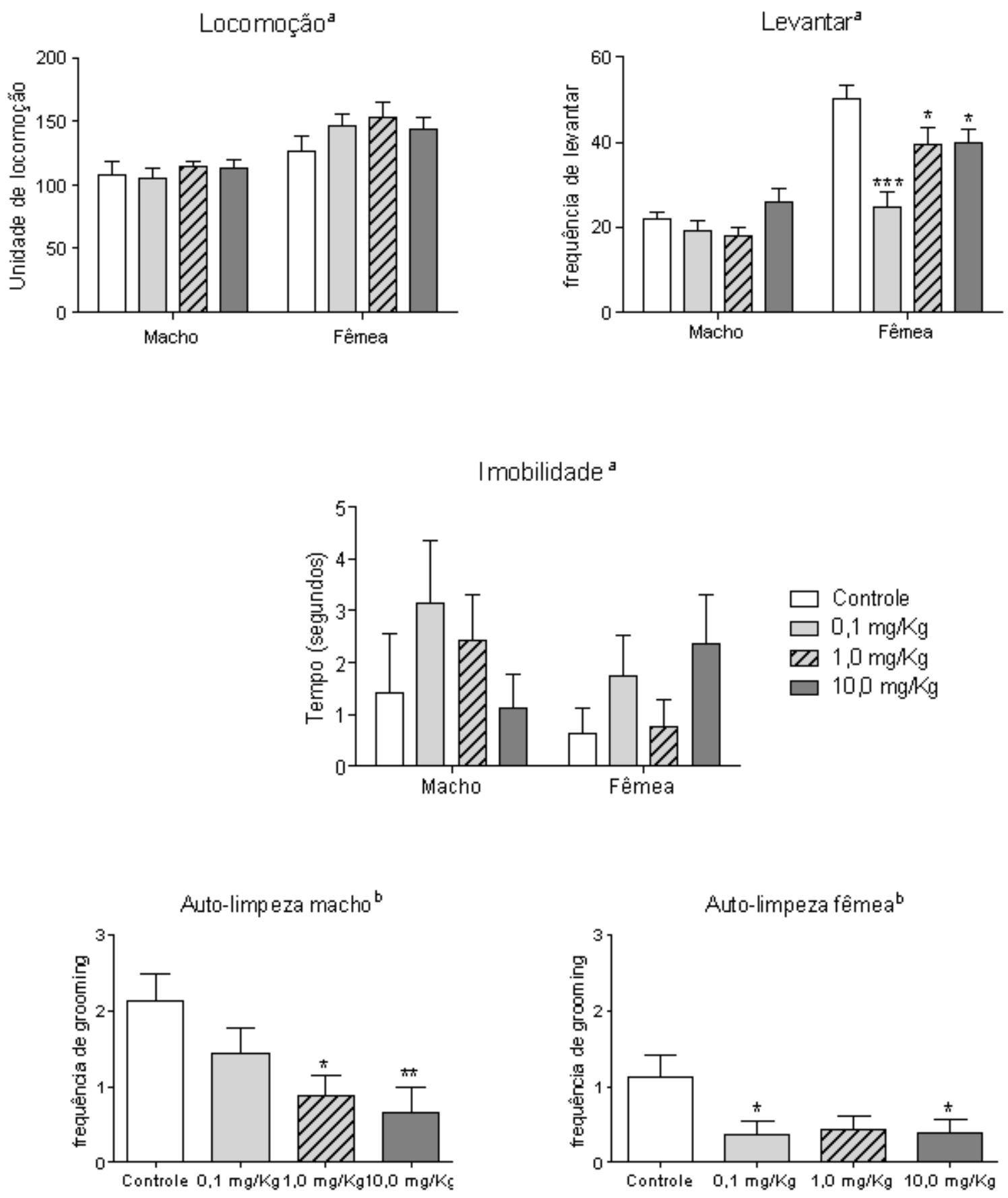

Figura 22: Parâmetros avaliados no teste de campo aberto, por 5 min, na prole adulta de ratas expostas ou não (controle) ao fipronil, do $6^{\circ}$ ao $20^{\circ}$ dia de gestação. Dados expressos em médias e respectivos erros padrão. ${ }^{a}$ ANOVA de duas vias, seguido pelo teste de Bonferroni: ${ }^{*} * \mathrm{p}<0,001 ;{ }^{*} \mathrm{p}<0,05 ;{ }^{\mathrm{b}}$ ANOVA de uma via, seguido pelo teste de Dunnett: ${ }^{*} \mathrm{p}<0,01$; $* \mathrm{p}<0,05$. 
No labirinto em cruz elevado, em relação à porcentagem de entradas em braço aberto (\%EBA), a ANOVA de uma via mostrou diferença significante entre os grupos apenas na prole masculina $(F(3 / 32)=8,56, p<0,001)$ e o teste de Dunnett mostrou que os animais do grupo de $10,0 \mathrm{mg} / \mathrm{Kg}$ apresentaram menor porcentagem de entradas nos braços abertos $(p<0,001)$ quando comparados aos animais do grupo controle.

Em relação à porcentagem de permanência nos braços abertos (\%TBA), a ANOVA de uma via mostrou diferença significante entre os grupos tanto para a prole masculina $(F(3 / 30)=24,08, p<0,001)$, quanto para a prole feminina ( $F$ $(3 / 31)=3,36, p<0,05)$. O teste de Dunnett mostrou que, na prole masculina, houve redução significante desse parâmetro em todas as doses quando comparados aos animais do grupo controle $(0,1$ e $10,0 \mathrm{mg} / \mathrm{Kg}-\mathrm{p}<0,001 ;$ e 1,0 $\mathrm{mg} / \mathrm{Kg}-\mathrm{p}<0,01)$; já na prole feminina, houve redução significante apenas no grupo de $0,1 \mathrm{mg} / \mathrm{Kg}(\mathrm{p}<0,05)$.

Em relação aos head-dipping dos animais observados no labirinto, a ANOVA de uma via mostrou diferença significante entre os grupos apenas na prole feminina $(F(3 / 26)=10,25, p<0,01)$ e o teste de Dunnett mostrou que houve redução da frequência desse parâmetro em todas as doses $(0,1$ e 1,0 mg/Kg $\mathrm{p}<0,05 ;$ e $10,0 \mathrm{mg} / \mathrm{Kg}-\mathrm{p}<0,001)$, em relação ao grupo controle.

Quanto ao stretched attend postures (SAP) avaliado no labirinto, a ANOVA de uma via mostrou diferença significante tanto na prole masculina $(F(3 / 36)=$ $11,35, p<0,01)$, quanto na prole feminina $(F(3 / 29)=3,66, p<0,05)$. $O$ teste de Dunnett mostrou aumento significante da frequência desse parâmetro no grupo 
masculino de $10,0 \mathrm{mg} / \mathrm{Kg}(p<0,001)$, e redução significante nos grupos femininos de $1,0 \mathrm{mg} / \mathrm{Kg}(\mathrm{p}<0,05)$ e $10,0 \mathrm{mg} / \mathrm{Kg}(\mathrm{p}<0,05)$ em relação ao grupo controle.

Tabela 18 - Parâmetros do comportamento em labirinto em cruz elevado da prole, na idade adulta, de ratas expostas ou não (controle) ao fipronil, do $6^{\circ}$ ao $20^{\circ}$ dia de gestação. Dados expressos em médias e respectivos erros padrão $(n=$ número de animais)

\begin{tabular}{cccccc}
\hline \multirow{2}{*}{ Parâmetro } & \multirow{2}{*}{ Sexo } & Controle & \multicolumn{3}{c}{ Fipronil $(\mathrm{mg} / \mathrm{Kg})$} \\
\cline { 4 - 6 } & & $(\mathrm{n}=9)$ & $0,1(\mathrm{n}=10)$ & $1,0(\mathrm{n}=9)$ & $10,0(\mathrm{n}=10)$ \\
\hline \% EBA & $\mathrm{M}$ & $35 \pm 1,64$ & $28 \pm 1,86$ & $29 \pm 1,65$ & $20 \pm 2,52^{* * *}$ \\
& $\mathrm{~F}$ & $35 \pm 2,81$ & $27 \pm 2,04$ & $29 \pm 1,93$ & $29 \pm 4,03$ \\
$\%$ TBA & $\mathrm{M}$ & $32 \pm 1,09$ & $10 \pm 1,35^{* * *}$ & $20 \pm 1,89 * * *$ & $22 \pm 1,97 * *$ \\
& $\mathrm{~F}$ & $41 \pm 1,94$ & $22 \pm 2,16^{*}$ & $31 \pm 2,91$ & $27 \pm 5,71$ \\
& $\mathrm{M}$ & $15 \pm 0,76$ & $13 \pm 1,08$ & $13 \pm 1,32$ & $12 \pm 0,86$ \\
& $\mathrm{~F}$ & $26 \pm 1,81$ & $18 \pm 1,82^{*}$ & $19 \pm 0,92^{*}$ & $13 \pm 1,20^{* * *}$ \\
SAP & $\mathrm{M}$ & $6 \pm 0,78$ & $6 \pm 0,73$ & $9 \pm 1,04$ & $17 \pm 1,81^{* * *}$ \\
& $\mathrm{~F}$ & $12 \pm 0,46$ & $9 \pm 0,90$ & $8 \pm 0,92^{*}$ & $7 \pm 1,08^{*}$
\end{tabular}

$\overline{\mathrm{EBA}}=$ Entradas nos braços abertos; TBA $=$ Tempo nos braços abertos; $H D=$ Head-dipping; $\mathrm{SAP}=$ stretched attend postures, $\mathrm{M}=$ Machos; $\mathrm{F}=$ Fêmeas.

ANOVA de uma via, seguida pelo teste de Dunnett: ${ }^{* *} \mathrm{p}<0,01 ;{ }^{* *} \mathrm{p}<0,01 ; * \mathrm{p}<0,05$. 
\% EBA - Machos

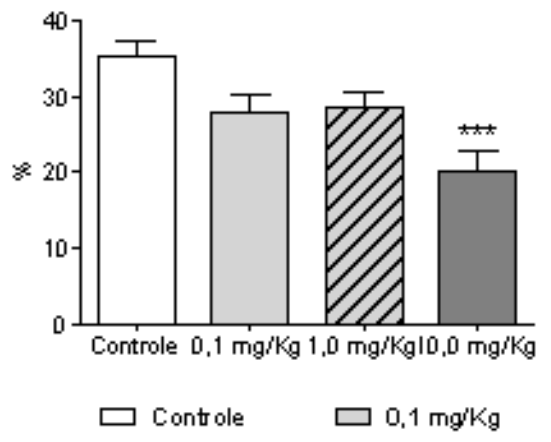

\% EBA -Fêmeas

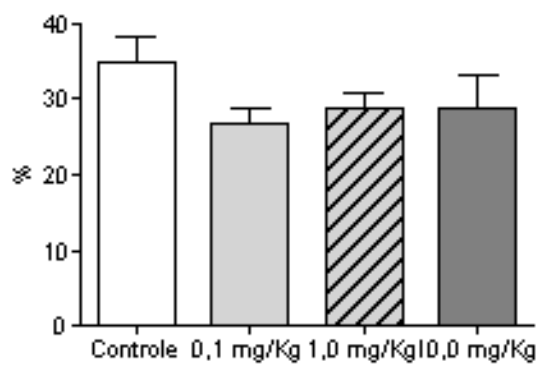

Heacldipping - Machos

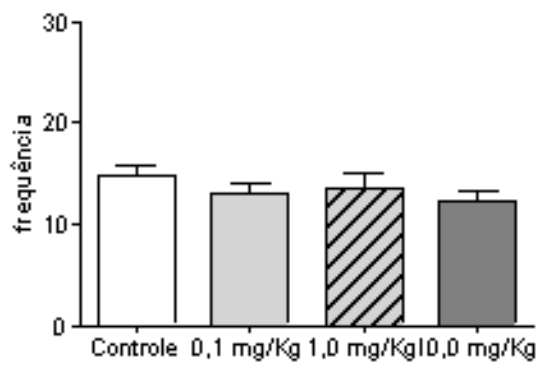

SAP-Machos

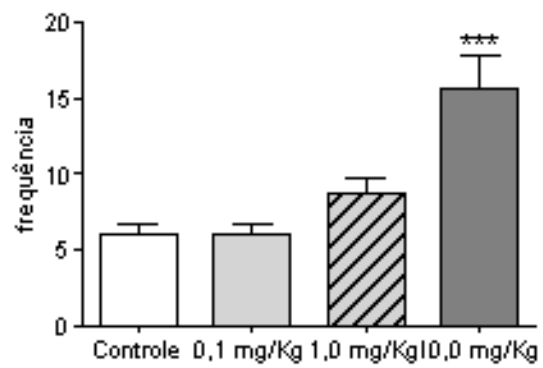

\% TBA - Machos

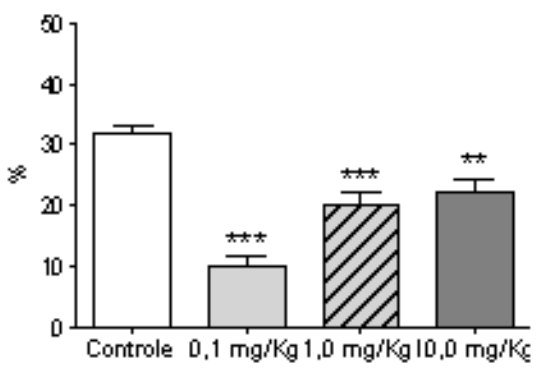

C $1,0 \mathrm{mg} / \mathrm{kg}$

$\square 10,0 \mathrm{mg} k g$

\% TBA -Fêmeas

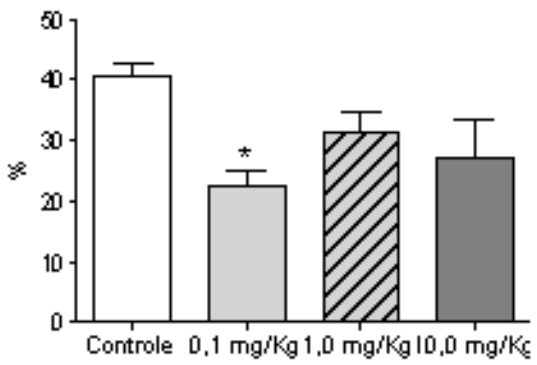

Head-dipping - Fêm eas

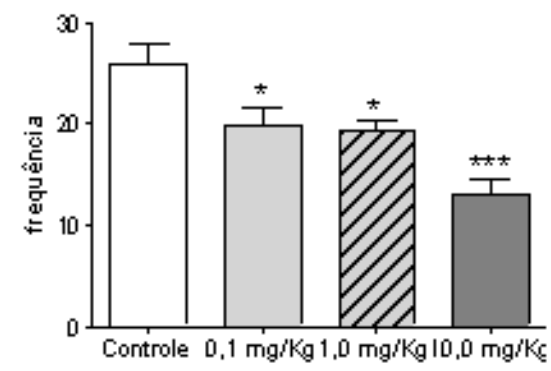

SAP-Fêmeas

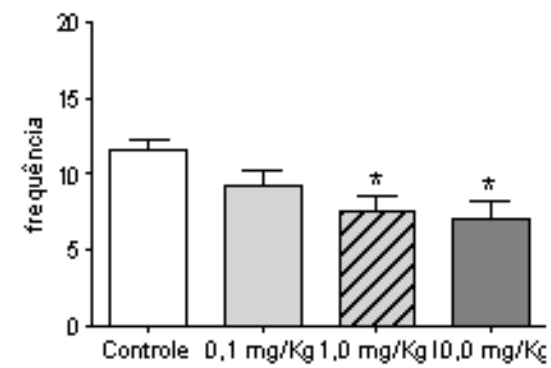

Figura 23: Parâmetros do comportamento em labirinto em cruz elevado da prole de ratas expostas ou não (controle) ao fipronil, do $6^{\circ}$ ao $20^{\circ}$ dia de gestação. Dados expressos em médias e respectivos erros padrão ( $S A P=$ stretched attend postures). ANOVA de uma via, seguida pelo teste de Dunnett: $* * * p<0,001,{ }^{*} \mathrm{p}<0,01 ; * \mathrm{p}<0,05$. 
A Figura 24 mostra o tempo de interação social, avaliado por 10 minutos, da prole de ratas exposta ao fipronil durante a gestação.

A análise de variância, de uma via, mostrou diferença significante entre os grupos, tanto na prole masculina $(F(3 / 30)=14,73, p<0,001)$, quanto na prole feminina $(F(3 / 31)=7,54, p<0,001)$; o teste de Dunnett mostrou que as fêmeas, cujas mães estiveram expostas ao fipronil na dose de $0,1 \mathrm{mg} / \mathrm{Kg}$, interagiram por menos tempo com suas companheiras, quando comparadas ao animais dos grupos controle, bem como os machos dos grupos de 1,0 e 10,0 $\mathrm{mg} / \mathrm{Kg}(\mathrm{p}<0,01$ e $\mathrm{p}<0,001$, respectivamente).

Interaçẫo Social de Machos

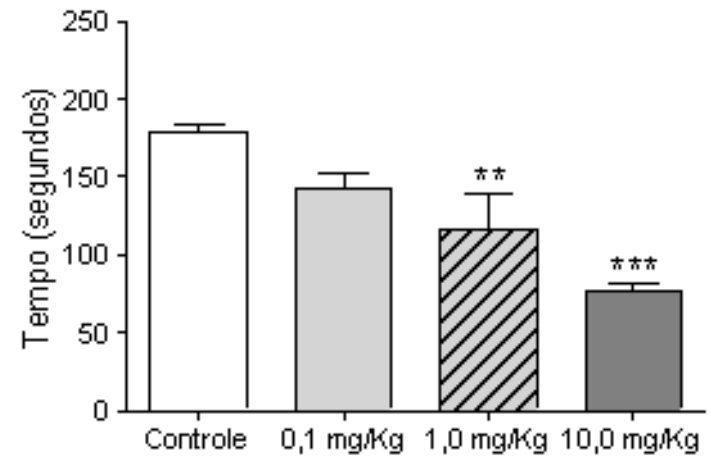

Interaçẫo Social de Fêmeas

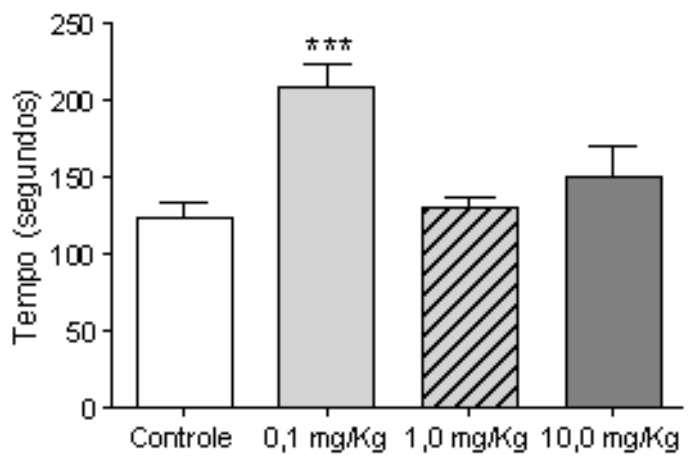

Figura 24: Tempo de interação social entre os animais cujas mães estiveram expostas, ou não (controle), ao fipronil do $6^{\circ}$ ao $20^{\circ}$ dia de gestação. Dados expressos em médias e respectivos erros padrão. ANOVA de uma via seguido pelo teste Dunnett: ${ }^{* *} \mathrm{p}<0,001 ;{ }^{* *} \mathrm{p}<0,01$. 


\section{Experimento 5.3.2: Efeito da administração de fipronil, durante a gestação, nos parâmetros sexuais da prole feminina}

Nesse experimento foi utilizada a prole feminina, adulta, cujas mães estiveram expostas ao fipronil do $6^{\circ}$ ao $20^{\circ}$ dia de gestação. Essa prole foi avaliada quanto aos parâmetros do ciclo estral (item 4.3.9) e comportamento sexual (item 4.3.11), sendo que este último antecedido da avaliação da coordenação motora em trave elevada, conforme descrito no item 4.3.8.

A Tabela 19 e a Figura 25 mostram o acompanhamento do ciclo estral, por 21 dias consecutivos, dessas fêmeas. A ANOVA de uma via mostrou diferenças significantes entre os grupos, tanto na fase de estro $(F(3 / 26)=5,19, p<0,05)$, quanto na fase de metaestro $(F(3 / 28)=4,92, p<0,01)$ e diestro $(F(3 / 27)=$ $4,42, p<0,05)$. O teste de Dunnett mostrou que as fêmeas do grupo de 0,1 $\mathrm{mg} / \mathrm{Kg}$ apresentaram aumento significante na incidência da fase de estro $(p<0,05)$, na fase de metaestro $(p<0,01)$ e redução significante na incidência da fase de diestro $(p<0,05)$, quando comparadas às fêmeas do grupo controle. Além disso, os animais tratados mostraram ciclo irregular durante os 21 dias de observação. 
Tabela 19 - Incidência de aparecimento das diferentes fases do ciclo estral, em 21 dias consecutivos, de fêmeas cujas mães estiveram expostas ou não (controle) ao fipronil, do $6^{\circ}$ ao $20^{\circ}$ dia de gestação. Dados expressos em médias e respectivos erros padrão ( $\mathrm{n}=8$ animais por grupo)

\begin{tabular}{lcccc}
\hline \multirow{2}{*}{ Fase estral } & Controle & \multicolumn{3}{c}{ Fipronil $(\mathrm{mg} / \mathrm{Kg})$} \\
\cline { 3 - 5 } & & 0,1 & 1,0 & 10,0 \\
\hline Proestro & $2,7 \pm 0,39$ & $2,6 \pm 0,32$ & $2,3 \pm 0,27$ & $2,6 \pm 0,37$ \\
Estro & $4,7 \pm 0,29$ & $6,0 \pm 0,35^{*}$ & $3,8 \pm 0,27$ & $4,0 \pm 0,32$ \\
Mestaestro & $2,7 \pm 0,18$ & $4,3 \pm 0,48^{* *}$ & $2,3 \pm 0,17$ & $3,7 \pm 0,29$ \\
Diestro & $4,2 \pm 0,24$ & $2,7 \pm 0,49 *$ & $4,6 \pm 0,28$ & $3,9 \pm 0,32$
\end{tabular}

ANOVA de uma via, seguida pelo teste de Dunnett: $* * p<0,01 ; * \mathrm{p}<0,05$.

A Figura 25 mostra a coordenação motora da prole feminina avaliada na trave elevada. A análise de variância, de um via, mostrou uma diferença significante entre os grupos $(F(3 / 31)=8,79, p<0,001)$ e o teste de Dunnett mostrou que as fêmeas do grupo de $10,0 \mathrm{mg} / \mathrm{Kg}$ apresentaram menor escore de erro $(p<0,05)$ quando comparadas aos animais do grupo controle. 
Proestro

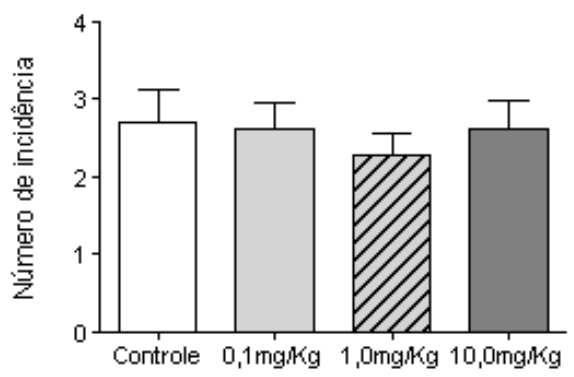

$\square$ Controle

$\square 0,1 \mathrm{mg} / \mathrm{Kg}$

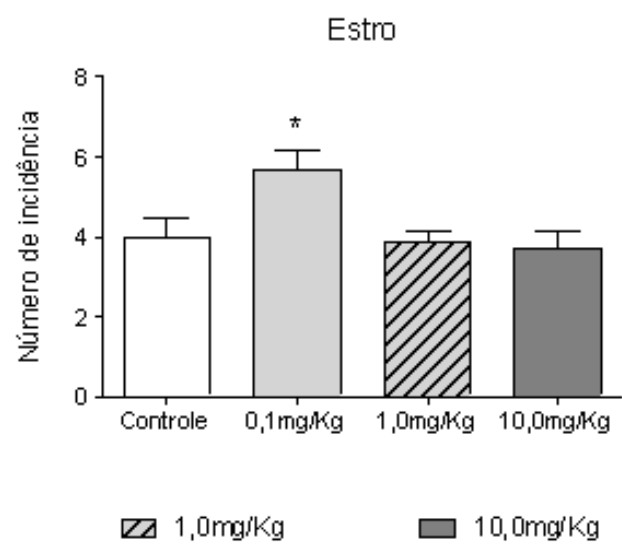

Metaestro

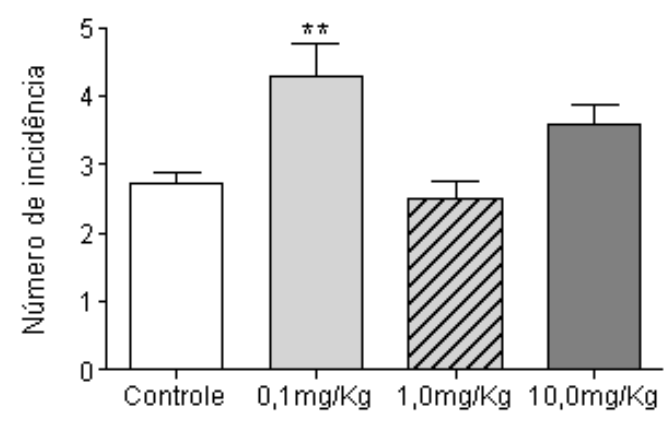

Diestro

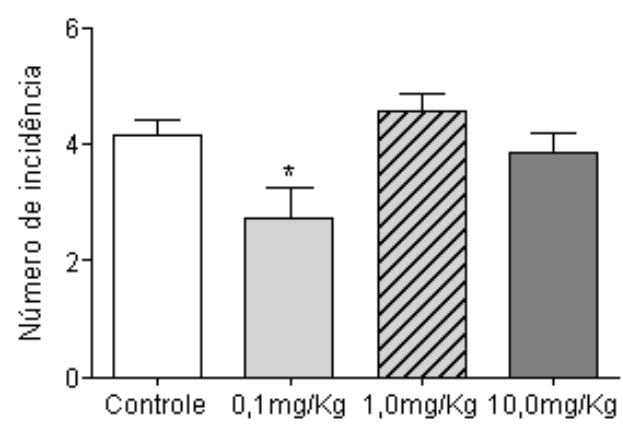

Figura 25: Incidência de aparecimento das fases do ciclo estral, em 21 dias consecutivos de observação, de fêmeas cujas mães estiveram expostas ou não (controle) ao fipronil, do $6^{\circ}$ ao $20^{\circ}$ dia de gestação. Dados expressos em médias e respectivos erros padrão. ANOVA de uma via seguida pelo teste de Dunnett: ${ }^{* *} \mathrm{p}<0,01 ;{ }^{*} \mathrm{p}<0,05$. 


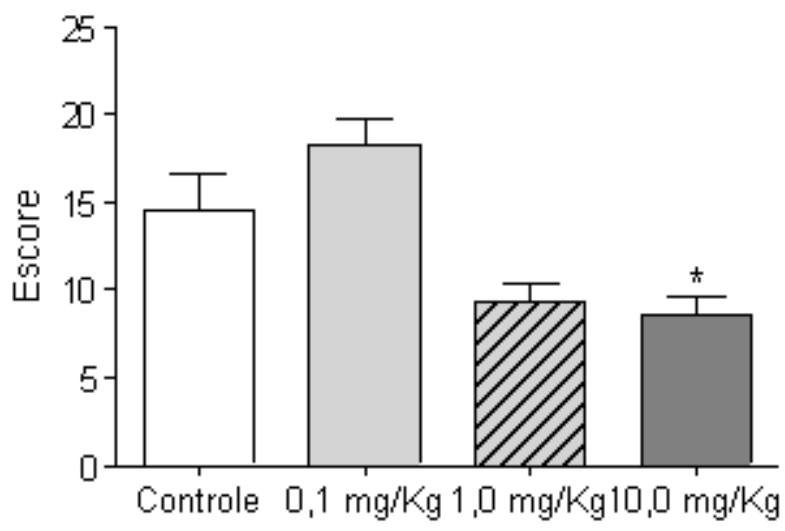

Figura 26: Escores de erros atribuídos aos passos do membro pélvico da prole feminina, cujas mães estiveram expostas ou não (controle) ao fipronil, do $6^{\circ}$ ao $20^{\circ}$ dia de gestação ( $n=9$ animais por grupo). Dados expressos em médias e respectivos erros padrão. ANOVA de uma via seguido pelo teste de Dunnett: ${ }^{*} p<0,05$.

Em relação ao comportamento sexual da prole feminina, a Figura 27 mostra os coeficientes de lordose das fêmeas, cujas mães estiveram expostas ao fipronil do $6^{\circ}$ ao $20^{\circ}$ dia de gestação; a análise de variância não mostrou diferença significante entre os grupos.

\section{Coeficiênte de Londose}

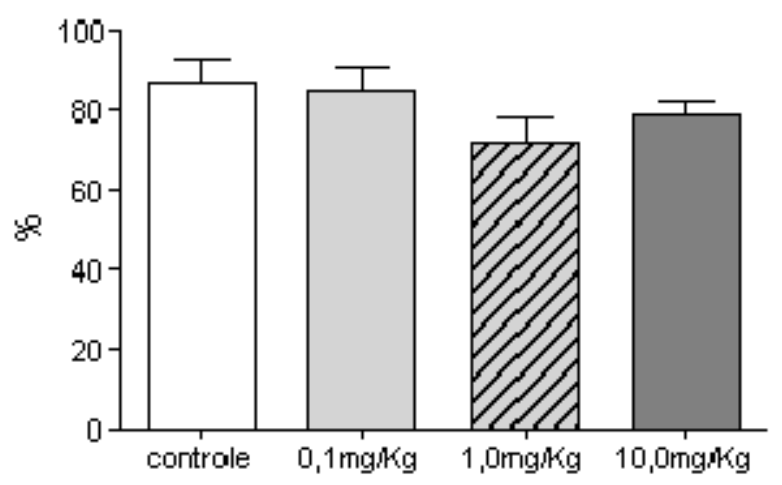

Figura 27: Coeficiente de lordose das ratas, cujas mães foram expostas ou não (controle) ao fipronil, do $6^{\circ}$ ao $20^{\circ}$ dia de gestação. Dados expressos em médias e respectivos erros padrão ( $n=8$ animais por grupo). ANOVA de uma via: $p>0,05$. 


\section{Experimento 5.3.3: Efeito da administração de fipronil, durante a gestação, no comportamento sexual da prole masculina}

A prole masculina utilizada nesse experimento foi proveniente das mães do Experimento 5.11. Antes da realização do comportamento sexual (conforme descrito no item 4.3.11), os animais foram avaliados quanto sua coordenação motora no aparato de trave elevada (item 4.3.8).

A Figura 28 mostra a coordenação motora da prole masculina exposta ao fipronil durante a gestação. A ANOVA de uma via mostrou diferença entre os grupos $(F(3 / 29)=11,06, p<0,001)$ e o teste de Dunnett mostrou que os machos do grupo de $1,0 \mathrm{mg} / \mathrm{Kg}$ apresentaram maiores escores de erro $(p<0,01)$, quando comparados aos animais do grupo controle.

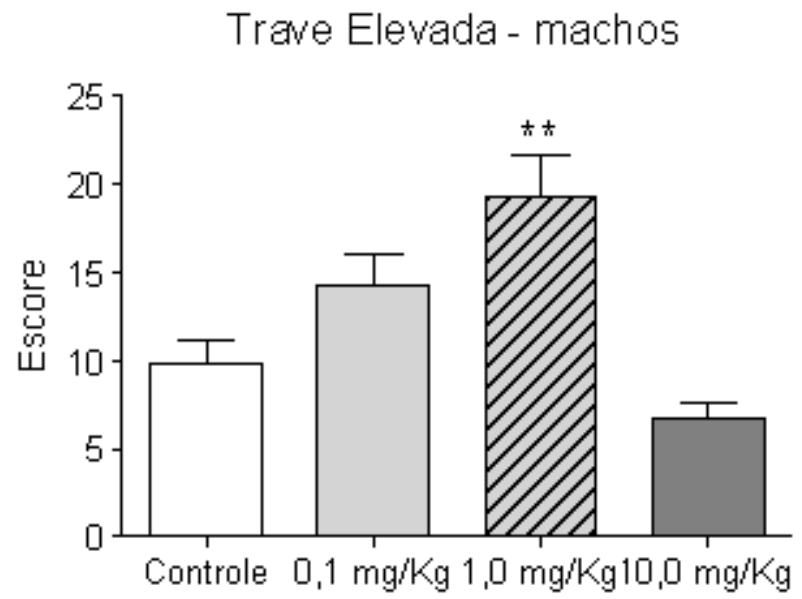

Figura 28: Escores de erros atribuídos aos passos do membro pélvico da prole masculina, cujas mães estiveram expostas ou não (controle) ao fipronil, do $6^{\circ}$ ao $20^{\circ}$ dia de gestação ( $n=9$ animais por grupo). Dados expressos em médios e respectivos erros padrão. ANOVA de uma via seguido pelo teste de Dunnett: $* * p<0,01$. 
Em relação ao comportamento sexual, a Tabela 20 mostra os parâmetros avaliados desse comportamento, na prole de ratas expostas ao fipronil durante a gestação.

Os únicos parâmetros onde a ANOVA de uma vida mostrou diferenças significantes entre os grupos foram: latência para a primeira monta $(F(3 / 23)=7,69, p<0,01)$ e latência para a primeira intromissão $(F(3 / 22)=$ $14,91, \mathrm{p}<0,001) ;$ o teste de Dunnett mostrou que os machos, cujas mães estiveram expostas à menor dose de fipronil, apresentaram maior latência em ambos parâmetros ( $p<0,01$ e $p<0,001$, respectivamente), em relação ao grupo controle. 
Tabela 20 - Parâmetros do comportamento sexual masculino da prole de ratas expostas ou não (controle) ao fipronil, do $6^{\circ}$ ao $20^{\circ}$ dia de gestação. Dados expressos em média e respectivos erros padrão ( $n=$ número de animais)

\begin{tabular}{|c|c|c|c|c|}
\hline \multirow{2}{*}{ Parâmetros } & \multirow{2}{*}{$\begin{array}{l}\text { Controle } \\
(n=7)\end{array}$} & \multicolumn{3}{|c|}{ Fipronil (mg/Kg) } \\
\hline & & $0,1(n=7)$ & $1,0(n=8)$ & $10,0(n=7)$ \\
\hline $\begin{array}{l}\text { Latência p/ } 1^{a} \\
\text { monta (s) }\end{array}$ & $28,8 \pm 5,26$ & $128,6 \pm 27,05^{* *}$ & $41,3 \pm 13,93$ & $24,7 \pm 7,49$ \\
\hline $\begin{array}{l}\text { Latência p/ } 1^{a} \\
\text { intromissão (s) }\end{array}$ & $48,8 \pm 8,75$ & $191,8 \pm 21,32 * * *$ & $97,3 \pm 27,82$ & $46,7 \pm 7,36$ \\
\hline $\begin{array}{l}\mathrm{N}^{\circ} \text { de montas } \\
\text { incompletas até a } \\
1^{\mathrm{a}} \text { ejaculação }\end{array}$ & $3,8 \pm 0,60$ & $5,5 \pm 1,06$ & $2,0 \pm 0,58$ & $4,5 \pm 0,71$ \\
\hline $\begin{array}{l}\text { Número de } \\
\text { intromissões até a } \\
1^{a} \text { ejaculação }\end{array}$ & $28,8 \pm 2,07$ & $34,2 \pm 2,95$ & $21,3 \pm 2,23$ & $34,2 \pm 2,29$ \\
\hline $\begin{array}{l}\text { Latência p/ 1a } \\
\text { ejaculação (s) }\end{array}$ & $1474 \pm 221,93$ & $1542 \pm 98,62$ & $1386 \pm 176,34$ & $1430 \pm 35,57$ \\
\hline $\begin{array}{l}\text { Latência p/ } 1^{a} \\
\text { monta pós- } \\
\text { ejaculação (s) }\end{array}$ & $282,1 \pm 9,58$ & $364,9 \pm 22,57$ & $291,4 \pm 24,31$ & $333,6 \pm 30,41$ \\
\hline $\mathrm{N}^{0}$ de ejaculações & $2,1 \pm 0,40$ & $1,4 \pm 0,20$ & $2,9 \pm 0,44$ & $1,9 \pm 0,26$ \\
\hline $\begin{array}{l}\text { Total de montas em } \\
40 \mathrm{~min}\end{array}$ & $47,8 \pm 3,25$ & $49,2 \pm 4,41$ & $46,2 \pm 4,43$ & $51,2 \pm 3,87$ \\
\hline $\begin{array}{l}\text { Frequência de } \\
\text { montas/min }\end{array}$ & $1,5 \pm 0,14$ & $1,6 \pm 0,18$ & $1,8 \pm 0,35$ & $1,7 \pm 0,15$ \\
\hline $\begin{array}{l}\text { Frequência de } \\
\text { intromissões/min }\end{array}$ & $1,4 \pm 0,15$ & $1,5 \pm 0,18$ & $1,6 \pm 0,33$ & $1,5 \pm 0,13$ \\
\hline $\begin{array}{l}\text { Intervalo inter- } \\
\text { intromissões }\end{array}$ & $0,7 \pm 0,07$ & $0,7 \pm 0,07$ & $0,6 \pm 0,09$ & $0,7 \pm 0,08$ \\
\hline $\mathrm{EC}(\%)$ & $89 \pm 2,26$ & $88 \pm 2,10$ & $94 \pm 1,34$ & $88 \pm 1,94$ \\
\hline $\begin{array}{l}\text { Número de animais } \\
\text { que não realizaram } \\
\text { o comportamento } \\
(\%)\end{array}$ & 30 & 30 & 20 & 30 \\
\hline
\end{tabular}




\section{Experimento 5.3.4: Efeito da administração de fipronil, durante a gestação, sobre as estruturas anatômicas da prole}

Um casal de cada ninhada, quando adulto (DPN130), foi submetido à eutanásia com anestesia profunda e as estruturas anatômicas foram avaliadas, conforme descrito no item 4.3.12.

A Tabela 21 mostra o peso dos órgãos da prole feminina proveniente de ratas expostas ao fipronil durante a gestação. A ANOVA de uma via não mostrou diferenças significantes entre os grupos nos pesos, ou pesos relativos dos órgãos, quando comparadas com as fêmeas do grupo controle.

A Tabela 22 mostra o peso dos órgãos da prole masculina de ratas expostas Mao fipronil durante a gestação. A ANOVA de uma via não mostrou diferenças significantes entre os grupos nos pesos, ou pesos relativos dos órgãos, quando comparadas com os machos do grupo controle. 
Tabela 21 - Peso real (g) e relativo (\%) dos órgãos de fêmeas, cujas mães estiveram expostas ou não (controle) ao fipronil, do $6^{\circ}$ ao $20^{\circ}$ dia de gestação. Dados em médias e respectivos erros padrão ( $n=10$ animais por grupo)

\begin{tabular}{|c|c|c|c|c|c|}
\hline \multirow{2}{*}{ Órgão } & \multirow{2}{*}{ Peso } & \multirow{2}{*}{ Controle } & \multicolumn{3}{|c|}{ Fipronil (mg/Kg) } \\
\hline & & & 0,1 & 1,0 & 10,0 \\
\hline \multirow{2}{*}{ Fígado } & Real & $7,4 \pm 0,2$ & $7,8 \pm 0,3$ & $7,1 \pm 0,3$ & $7,1 \pm 0,2$ \\
\hline & Relativo & $3,2 \pm 0,1$ & $3,1 \pm 0,2$ & $3,0 \pm 0,1$ & $3,0 \pm 0,1$ \\
\hline \multirow{2}{*}{ Baço } & Real & $0,5 \pm 0,0$ & $0,6 \pm 0,0$ & $0,5 \pm 0,0$ & $0,5 \pm 0,0$ \\
\hline & Relativo & $0,2 \pm 0,0$ & $0,2 \pm 0,0$ & $0,2 \pm 0,0$ & $0,2 \pm 0,0$ \\
\hline \multirow{2}{*}{ Pulmão } & Real & $1,4 \pm 0,1$ & $1,8 \pm 0,2$ & $1,5 \pm 0,1$ & $1,6 \pm 0,1$ \\
\hline & Relativo & $0,6 \pm 0,0$ & $0,7 \pm 0,1$ & $0,6 \pm 0,0$ & $0,7 \pm 0,0$ \\
\hline \multirow{2}{*}{$\operatorname{Rim} E$} & Real & $0,7 \pm 0,0$ & $0,8 \pm 0,0$ & $0,7 \pm 0,1$ & $0,7 \pm 0,0$ \\
\hline & Relativo & $0,3 \pm 0,0$ & $0,3 \pm 0,0$ & $0,3 \pm 0,0$ & $0,3 \pm 0,0$ \\
\hline \multirow{2}{*}{ Rim D } & Real & $0,7 \pm 0,0$ & $0,8 \pm 0,0$ & $0,7 \pm 0,0$ & $0,7 \pm 0,0$ \\
\hline & Relativo & $0,3 \pm 0,0$ & $0,3 \pm 0,0$ & $0,3 \pm 0,0$ & $0,3 \pm 0,0$ \\
\hline \multirow{2}{*}{$\begin{array}{c}\text { Adrenal E } \\
\qquad\left(10^{-2}\right)\end{array}$} & Real & $2,5 \pm 0,23$ & $2,6 \pm 0,28$ & $2,8 \pm 0,34$ & $2,6 \pm 0,16$ \\
\hline & Relativo & $1,1 \pm 0,11$ & $1,1 \pm 0,10$ & $1,2 \pm 0,12$ & $1,1 \pm 0,10$ \\
\hline \multirow{2}{*}{$\begin{array}{l}\text { Adrenal D } \\
\qquad\left(10^{-2}\right)\end{array}$} & Real & $2,4 \pm 0,15$ & $2,0 \pm 0,24$ & $2,3 \pm 0,26$ & $2,2 \pm 0,18$ \\
\hline & Relativo & $1,1 \pm 0,07$ & $0,8 \pm 0,08$ & $1,0 \pm 0,08$ & $0,9 \pm 0,08$ \\
\hline \multirow{2}{*}{$\begin{array}{c}\text { Ovário E } \\
\left(10^{-2}\right)\end{array}$} & Real & $6,6 \pm 0,28$ & $6,7 \pm 0,47$ & $6,5 \pm 0,36$ & $6,1 \pm 0,26$ \\
\hline & Relativo & $2,9 \pm 0,14$ & $2,7 \pm 0,20$ & $2,8 \pm 0,21$ & $2,6 \pm 0,11$ \\
\hline \multirow{2}{*}{$\begin{array}{c}\text { Ovário D } \\
\left(10^{-2}\right)\end{array}$} & Real & $6,5 \pm 0,46$ & $6,7 \pm 0,40$ & $6,6 \pm 0,58$ & $5,6 \pm 0,32$ \\
\hline & Relativo & $2,8 \pm 0,23$ & $2,8 \pm 0,23$ & $2,9 \pm 0,27$ & $2,3 \pm 0,15$ \\
\hline \multirow{2}{*}{$\begin{array}{c}\text { CV } \\
\left(10^{-2}\right)\end{array}$} & Real & $7,8 \pm 0,08$ & $6,8 \pm 0,55$ & $7,4 \pm 0,51$ & $6,1 \pm 0,40$ \\
\hline & Relativo & $3,4 \pm 0,04$ & $2,8 \pm 0,25$ & $3,1 \pm 0,18$ & $2,7 \pm 0,20$ \\
\hline \multirow{2}{*}{ Útero } & Real & $0,42 \pm 0,03$ & $0,41 \pm 0,04$ & $0,45 \pm 0,04$ & $0,44 \pm 0,05$ \\
\hline & Relativo & $0,19 \pm 0,01$ & $0,16 \pm 0,01$ & $0,19 \pm 0,02$ & $0,19 \pm 0,03$ \\
\hline \multirow{2}{*}{$\begin{array}{c}\text { Tireóide } \\
\left(10^{-2}\right)\end{array}$} & Real & $3,4 \pm 0,23$ & $4,6 \pm 0,69$ & $4,3 \pm 0,28$ & $3,7 \pm 0,36$ \\
\hline & Relativo & $1,5 \pm 0,10$ & $1,8 \pm 0,20$ & $1,9 \pm 0,10$ & $1,6 \pm 0,16$ \\
\hline
\end{tabular}


Tabela 22 - Peso real (g) e relativo (\%) dos órgãos de machos, cujas mães estiveram expostas ou não (controle) ao fipronil, do $6^{\circ}$ ao $20^{\circ}$ dia de gestação. Dados em médias e respectivos erros padrão ( $n=10$ animais por grupo)

\begin{tabular}{|c|c|c|c|c|c|}
\hline \multirow{2}{*}{ Órgão } & \multirow{2}{*}{ Peso } & \multirow{2}{*}{ Controle } & \multicolumn{3}{|c|}{ Fipronil (mg/Kg) } \\
\hline & & & 0,1 & 1,0 & 10,0 \\
\hline \multirow{2}{*}{ Fígado } & Real & $11,9 \pm 0,4$ & $12,1 \pm 0,7$ & $11,7 \pm 0,5$ & $11,9 \pm 0,5$ \\
\hline & Relativo & $2,9 \pm 0,0$ & $2,8 \pm 0,1$ & $2,8 \pm 0,1$ & $2,9 \pm 0,1$ \\
\hline \multirow{2}{*}{ Baço } & Real & $0,8 \pm 0,0$ & $0,8 \pm 0,0$ & $0,7 \pm 0,0$ & $0,8 \pm 0,0$ \\
\hline & Relativo & $0,2 \pm 0,0$ & $0,2 \pm 0,0$ & $0,2 \pm 0,0$ & $0,2 \pm 0,0$ \\
\hline \multirow{2}{*}{ Pulmão } & Real & $1,9 \pm 0,1$ & $2,4 \pm 0,2$ & $2,1 \pm 0,1$ & $2,1 \pm 0,2$ \\
\hline & Relativo & $0,5 \pm 0,0$ & $0,6 \pm 0,1$ & $0,5 \pm 0,0$ & $0,5 \pm 0,1$ \\
\hline \multirow{2}{*}{$\operatorname{Rim} \mathrm{E}$} & Real & $1,3 \pm 0,0$ & $1,3 \pm 0,1$ & $1,3 \pm 0,0$ & $1,3 \pm 0,0$ \\
\hline & Relativo & $0,3 \pm 0,0$ & $0,3 \pm 0,0$ & $0,3 \pm 0,0$ & $0,3 \pm 0,0$ \\
\hline \multirow{2}{*}{ Rim D } & Real & $1,2 \pm 0,0$ & $1,3 \pm 0,0$ & $1,3 \pm 0,1$ & $1,3 \pm 0,0$ \\
\hline & Relativo & $0,3 \pm 0,0$ & $0,3 \pm 0,0$ & $0,3 \pm 0,0$ & $0,3 \pm 0,0$ \\
\hline \multirow{2}{*}{$\begin{array}{c}\text { Adrenal E } \\
\qquad\left(10^{-2}\right)\end{array}$} & Real & $2,7 \pm 0,11$ & $2,8 \pm 0,08$ & $2,4 \pm 0,26$ & $2,6 \pm 0,15$ \\
\hline & Relativo & $0,65 \pm 0,02$ & $0,66 \pm 0,03$ & $0,57 \pm 0,07$ & $0,64 \pm 0,04$ \\
\hline \multirow{2}{*}{$\begin{array}{c}\text { Adrenal D } \\
\qquad\left(10^{-2}\right)\end{array}$} & Real & $2,6 \pm 0,13$ & $2,7 \pm 0,12$ & $2,3 \pm 0,13$ & $2,5 \pm 0,13$ \\
\hline & Relativo & $0,63 \pm 0,02$ & $0,63 \pm 0,04$ & $0,55 \pm 0,03$ & $0,61 \pm 0,04$ \\
\hline \multirow{2}{*}{ Testículo E } & Real & $1,9 \pm 0,0$ & $1,9 \pm 0,0$ & $1,9 \pm 0,0$ & $1,9 \pm 0,1$ \\
\hline & Relativo & $0,4 \pm 0,0$ & $0,4 \pm 0,0$ & $0,4 \pm 0,0$ & $0,5 \pm 0,0$ \\
\hline \multirow{2}{*}{ Testículo D } & Real & $1,9 \pm 0,0$ & $1,9 \pm 0,1$ & $1,8 \pm 0,0$ & $2,0 \pm 0,1$ \\
\hline & Relativo & $0,4 \pm 0,0$ & $0,4 \pm 0,0$ & $0,4 \pm 0,0$ & $0,5 \pm 0,0$ \\
\hline \multirow{2}{*}{ Próstata } & Real & $0,43 \pm 0,02$ & $0,38 \pm 0,01$ & $0,36 \pm 0,03$ & $0,41 \pm 0,03$ \\
\hline & Relativo & $0,10 \pm 0,00$ & $0,09 \pm 0,01$ & $0,08 \pm 0,01$ & $0,10 \pm 0,00$ \\
\hline Tireóide & Real & $5,5 \pm 0,36$ & $6,5 \pm 0,57$ & $6,0 \pm 0,41$ & $4,9 \pm 0,62$ \\
\hline$\left(10^{-2}\right)$ & Relativo & $1,4 \pm 0,08$ & $1,5 \pm 0,12$ & $1,4 \pm 0,10$ & $1,2 \pm 0,14$ \\
\hline
\end{tabular}

$\mathrm{E}=$ esquerdo; $\mathrm{D}=$ Direito.

ANOVA de uma via seguida pelo teste de Dunnett; $p>0,05$. 
6 Oiscussães

"O único homem que está isento de erros é aquele que não arrisca acertar"

(Albert Einstein) 
Em estudos pré-natais, com agentes tóxicos, é importante o estabelecimento de três doses, sendo que a maior delas deve produzir ligeira toxicidade materna, a menor não deve produzir qualquer efeito tóxico e a terceira seria uma dose intermediária entre elas. Tal fato é justificado, pois alterações na homeostase materna, promovidas por uma intoxicação, poderão se refletir na prole de maneira indireta; assim, não ficaria claro se os efeitos tóxicos dever-se-iam a uma intoxicação materna ou a um efeito direto nos filhotes. Além disto, atualmente são realizados testes longitudinais que avaliam não apenas alterações estruturais, como também modificações funcionais, que incluem o estudo do comportamento animal e análises bioquímicas, desde os primeiros dias de vida, na maturação sexual até a idade adulta (Bernardi, 2011).

Neste trabalho foram utilizadas três doses do fipronil: $0,1,1,0$ e 10,0 $\mathrm{mg} / \mathrm{Kg}$, baseados em dados anteriores de nosso grupo, que indicaram ligeira toxicidade na dose de $10,0 \mathrm{mg} / \mathrm{Kg}$, em ratos adultos expostos por 28 dias, caracterizada por redução na atividade geral em campo aberto e aumento de ansiedade em labirinto em cruz elevado.

Em ratas prenhes, como descrito nos resultados do Experimento 5.1.1, não houve alterações quanto ao consumo de água e, apenas as ratas expostas à maior dose de fipronil, apresentaram redução no consumo de ração na segunda semana de gestação, porém essa redução não interferiu no peso gestacional ou qualidade reprodutiva desses animais, nem nos demais grupos, quando comparadas ao grupo controle. Assim, pode-se sugerir que a maior dose 
empregada nesse estudo promoveu ligeira toxicidade materna sem causar prejuízos nos parâmetros da qualidade reprodutiva. Além disso, o peso das ninhadas dos grupos experimentais ao nascimento não diferiu daqueles dos animais do grupo controle, sugerindo que as diferentes doses de fipronil não causaram retardo no desenvolvimento físico fetal intra-uterino e nem prejudicaram o desenvolvimento físico pós-natal da prole.

Nos resultados do experimento 5.1.2, sobre o comportamento maternal, observou-se que $63 \%$ das ratas expostas à maior dose do fipronil agruparam todos seus filhotes em um período de tempo menor do que os animais do grupo controle. Ainda sobre o comportamento maternal, as ratas tratadas com 0,1 e 10,0 mg/Kg de fipronil apresentaram maior tempo de limpeza dos filhotes. Além disso, as ratas tratadas com 0,1 e 1,0 mg/Kg apresentaram maior frequência de auto-limpeza e as fêmeas da menor dose apresentaram menores escores na qualidade do novo ninho.

O comportamento maternal, resultado de mudanças hormonais que ocorrem no final da gestação e durante a lactação, envolve vários aspectos adaptativos que criam condições favoráveis para a sobrevivência de determinada espécie (CRUZ, 2009). Este é essencial para a sobrevivência e o crescimento dos filhotes (MOTTA et al., 2002). Na grande maioria das espécies de roedores, o filhote é bastante dependente da mãe, pois o recém nascido apresenta capacidades sensoriais bastante limitadas sendo incapaz de ver, ouvir ou se locomover de modo coordenado, além de não conseguir regular a temperatura corporal de forma independente. Portanto, os cuidados maternais 
nessa fase são intensos e fundamentais para a sobrevivência da prole (VIEIRA, 2003).

Segundo MOURA (2010), a recuperação e grupamento dos filhotes são necessários para a amamentação, sendo que a construção de ninho é essencial para garantir uma área segura aos filhotes.

O comportamento maternal é modulado pela estimulação somatosensorial que a fêmea recebe do filhote, como estímulos distais (som e cheiro), enquanto que a proximidade física com os filhotes desencadeia o comportamento maternal de forma efetiva, fazendo com que a mãe ofereça alimento, proteção e aquecimento (VIEIRA, 2003).

Em varias espécies de mamíferos, logo após o parto, a mãe lambe o líquido amniótico e o sangue remanescente. As lambidas da mãe, principalmente na região anogenital, são essenciais para estimular a micção do filhote. Substâncias químicas atrativas na urina dos filhotes parecem recompensar a mãe pelo seu desempenho. À medida que os filhotes crescem e vão se tornando independentes, capazes de se auto-regular termicamente e se alimentar, a mãe torna-se menos responsiva em relação aos filhotes (CRUZ, 2009).

A mãe, no comportamento maternal, é capaz de modular a aprendizagem e desenvolvimento do filhote, bem com é capaz de moldar as respostas comportamentais e expressão emocional da sua progênie quando esta atinge a idade adulta (MORICEAU e SULLIVAN, 2006).

Em um estudo realizado por WEAVER et al. (2004), os efeitos maternais influenciaram no desenvolvimento da resposta defensiva à perigos dos filhotes: 
mães que expressaram comportamento maternal excessivo geraram filhotes que, quando adulto, eram menos tímidos e mais exploradores.

É importante considerar que substâncias químicas, que atuam no sistema nervoso central, podem levar a alterações comportamentais, e que se essa exposição ocorrer durante o período gestacional, ou até mesmo se prolongar durante a lactação, pode gerar alterações comportamentais maternas, com repercussão na resposta comportamental da prole na idade adulta.

Nesse sentido, os resultados obtidos nesse trabalho mostram que, apesar de haver respostas diferenciadas de comportamento maternal das fêmeas tratadas com o fipronil em relação àquelas do grupo controle, parâmetros importantes como a latência para buscar o primeiro filhote e agrupar toda a ninhada, não foram prejudicados ou ocorreram de forma mais rápida; observou-se, ainda, que estas ratas lamberam mais seus filhotes. Desta forma, pode-se sugerir que não houve prejuízo no cuidado maternal e, portanto, possíveis alterações observadas na idade adulta da prole não podem ser conseqüências de prejuízos no cuidado maternal.

Existem várias evidências que o GABA modula o comportamento maternal, como, por exemplo, agonistas GABAérgicos aplicados localmente no sistema nervoso central, mais especificamente na área pré-óptica medial e lateral, inibem todos os parâmetros do comportamento maternal, exceto o lamber dos filhotes, que aumenta sob ação de bicuculina aplicada localmente na substância cinzenta pariaquedutal caudal (LEE; GAMMIE, 2010).

Barros et al. (1994) evidenciou a participação do GABA na modulação do comportamento de auto-limpeza. Esses autores mostram que o aumento da 
concentração de GABA reduz este comportamento. Uma vez que o fipronil atua como um antagonista GABAérgico, pode-se sugerir que tanto o aumento da auto-limpeza das mães, como o lamber os filhotes, observados no comportamento maternal possam ser devidos a ação GABAérgica do fipronil.

Atualmente, nos estudos de toxicologia do desenvolvimento é importante também considerar a teratologia comportamental, segundo a qual, a exposição a diversos fatores ambientais durante 0 desenvolvimento ou maturação cerebral do individuo, pode ocasionar alterações comportamentais tardias, manifestadas no decorrer da vida pós-natal (SPYKER, 1975). Portanto, além dos estudos clássicos referentes à ontogênese somática, utilizam-se aqueles relacionados à ontogênese cerebral, por meio de avaliações do desenvolvimento físico, sensorial e comportamental do individuo (SOBRIAN, 1977).

Os resultados do experimento 5.2.1, referentes ao desenvolvimento físico das proles dos grupos experimentais, não mostraram alterações quando comparados os parâmetros das proles de ratas do grupo controle, exceto no peso da prole feminina no DPN35 (inicio da puberdade), em que as fêmeas do grupo de 1,0 e 10,0 mg/Kg apresentaram maior peso corporal, confirmando, assim, a hipótese de que o tratamento pré-natal não causou prejuízo no desenvolvimento físico fetal.

Por outro lado, a exposição pré-natal ao fipronil promoveu alterações no desenvolvimento reflexológico, mais especificamente, atraso no reflexo de geotaxia negativa, tanto da prole masculina, quanto da prole feminina de ratas tratadas com a menor dose do inseticida. 
O estudo do desenvolvimento comportamental dos filhotes permite a avaliação da maturidade dos sistemas que controlam os diversos reflexos; por isso vários reflexos explorados quali e quantitativamente. A pressão palmar é um reflexo medular que tende a desaparecer no decorrer da vida pós-natal dos filhotes. Por sua vez, os ajustes posturais são regulados por três sistemas: vestibular, esteroceptivo e proprioceptivo. O reflexo postural e a geotaxia negativa de ratos jovens refletem o desenvolvimento motor e atividades controladas pelo sistema vestibular. A integridade do sistema vestibular também pode ser avaliada por meio da atividade motora geral do animal. Por isso, com a finalidade de se estudar o desenvolvimento do sistema vestibular, a atividade motora geral foi acompanhada por sete dias consecutivos, em campo aberto, do DPN15 ao DPN21.

Originalmente, o teste de campo aberto (CA) foi empregado por Calvin Hall, e este relacionava a defecação do animal com um índice de timidez, ou emocionalidade (HALL, $1934^{1}$ apud WALSH; CUMMINS, 1976); atualmente, este teste é bastante utilizado para avaliar a atividade locomotora e exploratória, relacionando-as ou não a emocionalidade dos roedores (MARTINS, 2009).

Segundo WALSH e CUMMINS (1976), o comportamento no campo aberto irá depender de como o animal irá responder frente a uma variedade de fatores como: a retirada do seu ambiente moradia; a transferência deste animal para o aparato de campo aberto; como o animal irá reagir ao ambiente novo e à sala em que se encontra o aparato; além de experiências anteriores, pois um animal

\footnotetext{
${ }^{1}$ Hall, C. S. Emotional behavior in the rat: Defecation and urination as measures of individual differences in emotionality. Journal of Comparative Psychology. v. 18, p. 385-403, 1934.
} 
re-exposto ao aparato responderá de maneira diferente que um animal submetido ao teste pela primeira vez.

Um dos fatores relevantes na observação do comportamento do animal é a sua tendência a movimentar-se, conhecida como atividade geral. A quantificação dessa locomoção pode refletir o comportamento, uma vez que o animal permanecerá imóvel ("freezing") quando apresentar alto grau de ansiedade. Nesse sentido, ARCHER (1973) ressaltou que a exploração do roedor é inversamente proporcional ao medo, ou emocionalidade: "a alta emocionalidade inibe a exploração e a baixa emocionalidade a facilita".

Além da locomoção, o comportamento de levantar (onde o animal fica apoiado nas patas traseiras, eleva o tronco para farejar o ambiente verticalmente) é a manifestação de um processo exploratório de aproximação das regiões modificadas do ambiente. Este parâmetro tende a aumentar de freqüência frente à estimulação nova (MARTINS, 2009).

Como ambientes abertos são naturalmente aversivos para os ratos, então os animais tendem a permanecer mais tempo na periferia do aparato de campo aberto do que no centro, mantendo suas vibrissas e corpo em contato com a parede do campo; este comportamento é chamado de tigmotaxia, uma estratégia evoluída para evitar predadores, sobretudo os predadores aéreos (BERNARDI e PALERMO-NETO, 1980; MORATO, 2006). O comportamento de auto-limpeza (ou auto "grooming') observado no campo aberto, tem sido tomado como a expressão de um decréscimo na emocionalidade e mostra independência das situações de medo (MARTINS, 2009). 
A análise, do perfil do desenvolvimento da atividade locomotora, das proles masculina e feminina, observadas em campo aberto, mostra que o perfil do desenvolvimento motor foi modificado pela exposição às três doses do fipronil (Figura 19), sendo que o nível de atividade locomotora foi maior nos animais expostos pré-natalmente às doses de 0,1 e $1,0 \mathrm{mg} / \mathrm{kg}$ do inseticida.

Segundo ALTMAN e SUDARSTHAN (1975), a postura de andar sobre as quartas patas do rato torna-se predominante entre os dias 12 e 13 de vida. Quando o animal tem seus olhos abertos (entre dias 14 e 15), ele passa a andar de maneira normal ou até mesmo com levantamento exagerado da pélvis. Nos dias subsequentes, a velocidade de locomoção aumenta, e no dia 16 ele apresenta atividade de corrida, raramente levantando o quadril. Além disso, a quantidade do número de unidades de locomoção no campo aberto reflete a maturação dos estágios locomotores. No dia 15, há aumento repentino à variável, com aumento do nível. É concebível que estes estágios também reflitam a maturação dos sistemas sensoriais envolvidos no comportamento exploratórios.

Assim, na prole masculina do presente trabalho, verificou-se que, no grupo controle, a frequência de locomoção aumentou paulatinamente até o DPN19, seguindo-se por estabilização. Ao contrário, nos filhotes de ratas expostas à dose de $0,1 \mathrm{mg} / \mathrm{Kg}$ constatou-se que o nível da atividade motora foi maior que do grupo controle, apresentado um pico de atividade no DPN21. Nos filhotes de ratas expostas à dose de $1,0 \mathrm{mg} / \mathrm{Kg}$ verificou-se a ocorrência de um pico no DPN16, seguido de estabilização até o DPN 21, quando ocorreu um segundo pico do parâmetro. Por outro lado, o perfil da atividade geral dos filhotes de 
ratas expostas à maior dose do fipronil foi muito semelhante àquele dos animais do grupo controle. Portanto, a exposição pré-natal ao fipronil elevou o nível da atividade geral dos animais durante todo o desenvolvimento da atividade motora e, em particular, no dia do desmame. Pode-se sugerir também que esse incremento foi na forma de um $\mathrm{U}$ invertido, desde que na maior dose, o perfil do desenvolvimento da atividade locomotora foi similar aquela do grupo controle.

As análises dos perfis da frequência de levantar e imobilidade sugerem aumento da atividade motora dos animais nos dias iniciais de observação no campo aberto e no desmame, uma vez que houve aumento concomitante do levantar com aquele da locomoção e redução da imobilidade.

Nas fêmeas, observou-se perfil diverso para a locomoção. De fato, com as dose de 1,0 e $0,1 \mathrm{mg} / \mathrm{Kg}$ verificou-se, respectivamente um pico de atividade nos DPN16 e 17. Nestes animais o nível de atividade se manteve alto e ocorreu um segundo pico de atividade ao desmame. Novamente, os filhotes de ratas expostas a maior dose do fipronil apresentaram um perfil similar ao daqueles filhotes do grupo controle. Da mesma forma que na prole masculina, notou-se que ocorreu aumento no levantar e paralelamente redução na imobilidade.

Desta forma, pode-se sugerir que a exposição pré-natal às doses de $0,1 \mathrm{e}$ $1,0 \mathrm{mg} / \mathrm{Kg}$ promoveram aumento da atividade motora das proles, masculina e feminina, e alteração no perfil do desenvolvimento motor dos mesmos.

Muito estudos mostram que a atividade motora em campo aberto é regida por diferentes áreas do cérebro, como o estriado, núcleo acumbens, ventromedial do tálamo, substância negra e cerebelo, e pelo balaço entre os 
sistemas dopaminérgico e GABAérgico, podendo também ser modulado pelos sistemas serotoninérgicos e colinérgicos (JONES; MOGENSON; WU, 1990).

TEGNÉR et al. (1993) observaram, no tronco cerebral de lampreia (modelo de estudo das coneç̧ões neuronais que controlam o comportamento motor em vertebrados), que ambos os receptores $\mathrm{GABA}_{A}$ e $\mathrm{GABA}_{B}$ mostraram papel modulador da coordenação da locomoção. KRIM et al. (1998) mostraram que a transmissão GABAérgica, na substância nigra reticulada, exercia papel crucial no controle da atividade motora. JONES; MOGENSON e WU (1990) mostraram, ainda, que GABA, na área do núcleo acumbens, possui ação bimodal na locomoção, onde baixas doses favoreceriam leve aumento da locomoção e altas doses levariam a redução da locomoção. É também sabido que, a estimulação de receptores $\mathrm{GABA}_{B}$ reduz a atividade locomotora (AGMO; PAREDES, 1985).

Desde que a administração pré-natal do fipronil, que atua inibindo receptores de canais de cloro do receptor GABAérgico, promoveu aumento da atividade geral dos filhotes de ratas expostos às doses de 0,1 e $1,0 \mathrm{mg} / \mathrm{Kg}$, é possível sugerir que o sistema dopaminérgico destes animais possa estar exacerbado provavelmente por redução na atividade GABAérgica.

Quanto aos resultados dos experimentos 5.3.1, referente aos estudos na prole adulta, foi observado em campo aberto que, diferentemente do achado na infância, a prole feminina apresentou redução no levantar e, em ambos os sexos, houve diminuição da auto-limpeza, sem alteração na locomoção.

A frequência de levantar é tida como dependente da ativação de vias estriatais e de dopamina, podendo ser modulada ou não pelo sistema GABAérgico (BERNARDI; PALERMO-NETO，1979; BERNARDI; DE SOUZA; 
PALERMO-NETO, 1981; SOUZA SILVA et al, 2008; WANG et al, 2011). Para tentar entender estes resultados é importante analisar em conjunto, os resultados obtidos nos testes do labirinto em cruz elevado e da interação social.

O teste do labirinto em cruz elevado foi criado por Montgomery em 1955 e é um dos principais modelos usados no estudo da ansiedade (CORREIA, 2009). Esse teste é baseado no comportamento exploratório de locais novos e na observação de respostas comportamentais em situações que poderiam ou não provocar perigo (RODGERS; DALVI, 1997); ele consiste em analisar o grau de aversão do animal aos braços abertos (BA), em conflito com comportamento exploratório (RODGERS et al., 1997).

O comportamento normal de exploração do rato é a favor dos braços fechados (BF) (HOGG, 1996); a causa da aversão aos BAs tem sido explicada por diferentes hipóteses: 1) esquiva natural que os roedores apresentam em relação à novidade; 2) medo da altura do aparato, e 3) a impossibilidade do animal realizar o comportamento de tigmotaxia nos BAs do labirinto (LISTER, 1990; MORATO, 2006). Mesmo existindo aversão aos BA, o animal ainda se arrisca a explorá-los (ENNACEUR; MICHALIKOVA; CHAZOT, 2006), assim, levantou-se a hipótese de que a estimulação provocada pela novidade (o ambiente novo) produziria reações de conflito entre medo e curiosidade, evidenciadas pelas tendências à esquiva e aproximação, respectivamente, observadas no parâmetro de stretched attend postures (SAP) (RODGERS; DALVI, 1997; MORATO, 2006; MARTINS, 2009).

O teste de interação social, criado em 1978 e validado em 1980 por FILE consiste em avaliar o tempo total de interação entre um par de animais, com 
pesos corporais variando apenas em 10 gramas, e mesmas experiências de manipulação e tratamento, mas que não tivessem conhecimento prévio um do outro. O comportamento de interação social inclui uma variedade de comportamentos como: farejar um ao outro, seguir o companheiro, passa sobre ou sob o companheiro e lamber no companheiro. (FILE; POPE, 1974; FILE; HYDE, 1978; FILE, 1980; SALGADO, 2006; LINCK, 2008; SALVIANO, 2008). A diminuição da atividade de interação social é correlacionada à outros comportamentos como o aumento da emocionalidade, diminuição da locomoção, defecação e freezing. (FILE, 1980).

Os resultados obtidos nesse trabalho mostraram que, em labirinto em cruz elevado na idade adulta, tanto a prole masculina, quanto a feminina, apresentaram maior aversão aos BAs, sendo maior evidenciado na prole feminina, e que essa aversão promoveu diminuição da exploração, dosedependente, dessas fêmeas, nos parâmetros de Head-dipping e SAP. Nos machos, houve redução apenas no parâmetro de $S A P$, na dose de $10,0 \mathrm{mg} / \mathrm{Kg}$, quando comparados aos animais do grupo controle. Esse aumento de ansiedade também pode ser visto no teste de interação social, onde a prole masculina, apresentou menor tempo de interação com seus parceiros, também dose-dependente. $\mathrm{O}$ interessante foi que neste modelo, as fêmeas de mães expostas a menor dose do fipronil mostram aumento da interação social.

Tomando-se em conjunto os dados do labirinto em cruz elevada, da interação social e do campo aberto pode-se então atribuir a redução do levantar, que representa atividade exploratória vertical, e da auto-limpeza, que representa estado de baixa estimulação, ao aumento de ansiedade. 
Como já citado, altos níveis de ansiedade e/ou emocionalidade levam a redução da atividade em campo aberto. Assim, pode-se sugerir que o fipronil, administrado em fase precoce do desenvolvimento da prole, teria modificado a atividade do eixo hipotálamo-hipófise-adrenal (HPA), ou seja, sua responsividade ao estresse.

Durante o desenvolvimento, o sistema nervoso central (SNC) é extremamente plástico para as intervenções do ambiente. A experiência é essencial durante as primeiras semanas pós-natais em que as atividades sensoriais se refinam e estabelecem conexões neurológicas estáveis. Sabe-se que, os filhotes de mãe que passaram por algum evento ou estresse durante a gestação podem apresentar alterações no seu desenvolvimento global, desta forma o comportamento maternal se apresenta como fundamental para o desenvolvimento inicial de recém-nascidos (SALE et al., 2007).

No entanto, segundo LEVINE (2001), no final da gestação e nos primeiros dias de vida, os níveis de glicorticóides ainda são altos na prole de ratos. A seguir, ocorre um período de hiporresponsividade do eixo HPA, que perdura até o décimo quarto dia pós-natal. Nota-se, ainda, que os níveis de acetilcolina e do hormônio liberador de corticotropina $(\mathrm{CRH})$ nas duas últimas semanas da lactação são bastante baixos (WALKER et al., 1986). Portanto, pode-se sugerir que o aumento da atividade geral, na lactação, das proles expostas ao fipronil derive da ausência de ativação do eixo HPA e predominância do sistema dopaminérgico. Por outro lado, na idade adulta, sugere-se neuroplasticidade do sistema, com ativação do eixo HPA, gerando aumento da ansiedade e redução da atividade geral em campo aberto. 
No comportamento sexual da prole masculina exposta pré-natalmente ao fipronil verificou-se redução nas latências para primeira monta e primeira intromissão, não sendo observadas diferenças significantes nos demais parâmetros, entre os grupos.

É fato conhecido, há bastante tempo, que antagonistas de receptores GABAérgicos, como a picrotoxina e o pentilenotrazol, ativam o eixo HPA e produzem liberação de corticóides (SILVA et al., 1995; LAL \& EMMETTOGLESBY, 1983) de forma similar ao estresse. Ainda, o estresse peri e pré-natal promove desmasculinização do cérebro fetal em desenvolvimento (SILVA et al., 1998). SILVA et al (1998) e GERARDIN et al. (2005), mostraram que a administração perinatal de picrotoxina aumentou as latências para primeira monta e ejaculação e, mais ainda, reduziu o número de ejaculações.

Nos mamíferos, após a diferenciação das gônadas durante a gestação, ocorre um fenômeno denominado diferenciação sexual hipotalâmica (MACLUSKY e NAFTOLIN, 1981), mediada por hormônios gonadais que resulta em diferenças morfológicas e comportamentais entre machos e fêmeas adultos (McCARTHY et al., 1997). Muitas evidências sugerem que a diferenciação sexual hipotalâmica, em ratos machos, é dependente da ação da testosterona, a qual deve ser metabolizada a estradiol, levando a desfeminização e a masculinização do SNC. O período neonatal crítico para o desenvolvimento de futuras conexões receptor-hormônio no SNC ocorre durante a gestação e logo no início da lactação (DAVIS; GORSKI, 1985). Na ausência do hormônio, no período crítico, a conexão receptor-hormônio pode ser alterada, causando modificações morfológicas e comportamentais (GERARDIN et al., 2005). 
Portanto, uma hipótese para explicar o prejuízo do comportamento sexual da prole masculina, de ratas tratadas com o fipronil (um antagonista GABAérgico) seria que, o inseticida, por promover estresse pré-natal, não permitiria a perfeita masculinização do hipotálamo. Este resultado poderia justificar a atribuição dada recentemente ao fipronil de desregulador endócrino. Reforça ainda esta proposta, o fato de que só na menor dose foram observadas interferências no comportamento sexual, pois os desreguladores endócrinos produzem seus efeitos em baixas doses.

No entanto, nota-se que apenas as latências para primeira monta e primeira intromissão, parâmetros ligados à motivação sexual, foram modificadas pelo tratamento pré-natal, sem haver prejuízo na eficiência copulatória. Em um processo de desmasculinização seria esperada também redução no número de ejaculações, como mostraram SILVA et al. (1998) e GERARDIN et al. (2005), porém é importante salientar que esses autores expuseram seus animais ao estresse em diferentes períodos do que ao período do presente estudo. Assim, pode-se sugerir que o fipronil administrado prénatalmente não causou desmasculinização, comprovado pela ausência de efeitos no dia da descida dos testículos, uma vez que a mesma depende da presença de níveis adequados da testosterona ao nascimento, mas modificou a motivação desses animais.

Outro aspecto que poderia ter produzido as alterações no comportamento sexual da prole masculina, exposta pré-natalmente ao fipronil, poderia ser resultado de incoordenação motora, uma vez que antagonistas GABAérgicos prejudicam a coordenação motora (AGMO; PAREDES, 1985). De fato, para a 
execução do comportamento sexual de machos é imprescindível que sua coordenação motora esteja integra. Porém, observou-se que a coordenação motora da prole masculina foi modificada apenas no grupo tratado com a dose de $1,0 \mathrm{mg} / \mathrm{Kg}$ e não na menor dose, como era esperado. Desta forma, não se pode atribuir o prejuízo do comportamento sexual da prole masculina à incoordenação motora.

Outra hipótese, que explicaria a redução da motivação da prole masculina das ratas tratadas com $0,1 \mathrm{mg} / \mathrm{Kg}$ do fipronil, poderia ser aventada com relação às modificações no desenvolvimento e maturação do sistema GABAérgico. Existem evidências de que GABA, via ativação de receptores $G A B A_{A}$, é um fator importante para a proliferação das células de Leydig e regulação da função dessas células no organismo em desenvolvimento (GEIGERSEDER et al., 2004). Sabe-se ainda, que as células de Leydig produzem testosterona quando estimulados pelo hormônio luteinizante (LH) e que GABA atua como estimulador da secreção de LH (ZANATTA, 2011). GERIANNE et al (1994) mostraram que os níveis de testosterona são crucias na expressão da motivação sexual. Assim, é possível que a exposição pré-natal ao fipronil tenha alterado a expressão dos receptores GabAérgicos nas células de Leyid nos testículos em formação e, portanto, os níveis de testosterona na prole foram suficientes para reduzir apenas a motivação, sem comprometer outros parâmetros do comportamento sexual.

As hipóteses para tentar entender os efeitos pré-natais do fipronil são apenas suposição, uma vez que os sistemas nervoso e endócrino são complexos e muito mais ainda as interações entre eles. 
Na prole feminina, a administração pré-natal de fipronil alterou a ciclização em todas as doses, porém essa desregulação foi evidente na prole cujas mães receberam a dose de $0,1 \mathrm{mg} / \mathrm{Kg}$ de fipronil, na qual aumentou a frequência da fase de estro e metaestro, reduzindo a fase de diestro. No entanto, a desregulação do ciclo estral não modificou o comportamento sexual destas fêmeas.

Muitos são os estudos que mostraram a interação do sistema GABAérgico modulando outros sistemas, como, por exemplo, o sistema dopaminérgico na atividade motora ou a função das células de Leydig nos testículos, como citados anteriormente; desse mesmo modo, o sistema GABAérgico também tem ação sobre as funções ovarianas, conhecidas desde 1985, quando ERDÕ, VARGA e HORVÁTH (1982) mostram que o sistema GABAérgico estava envolvido com o aumento do fluxo sanguíneo ovariano, bem como estava envolvido com a diminuição da secreção de progesterona e melhora da liberação de estradiol; também se conhece que o aumento das concentrações de GABA no fluído cérebro-espinal inibe o aparecimento do comportamento de receptividade sexual e que este comportamento pode ser inibido, ou melhor, a receptividade pode ser ativada pela ação de antagonistas $\mathrm{GABA}_{\mathrm{A}}$, injetados intracerebroventricularmente (QURESHI et al., 1988).

Neste sentido, sugere-se que a administração do fipronil interferiu com o desenvolvimento e/ou expressão dos receptores GABAérgicos nos ovários da prole feminina, modificando a atividade do eixo hipotálamo-hipófise-gonadal (HPG), causando irregularidade no ciclo estral. 
É interessante salientar que o hipotálamo é um importante centro integrador de informações que garantem a homeostase do organismo, a coordenação de funções viscerais e a iniciação de comportamentos, como a reprodução (SIMERLY, 2004). A função reprodutiva é regulada por regiões especificas do hipotálamo que controlam a hipófise e gônadas, formando o eixo HPG.

No presente estudo, mesmo havendo alterações no ciclo estral da prole de ratas tratadas com fipronil, não houve prejuízo ou alterações no comportamento sexual dessas fêmeas, expressos em coeficiente de lordose.

O reflexo de lordose, como o próprio nome diz, é um reflexo sensorial em resposta à monta do macho e pode ser ativado independente da presença de progesterona (MANI, 2001); a monta do macho produz estimulação de receptores sensoriais localizados nos flancos da fêmea, iniciando o impulso nervoso que chega até a medula espinhal e, posteriormente, na formação reticular e substância cinzenta periaquedutal (PFAFF et al., 1994); em resposta à esse estimulo há ativação dos neurônios motores da medula espinhal, que controlam os músculos envolvidos no reflexo de lordose (PFAFF et al., 2008). Além disso, existem evidencias de que o GABA tem papel crucial na expressão desse reflexo, onde agonistas $G A B A_{A}$ e $G A B A_{B}$ foram capazes de inibir a lordose (AGMO; SORIA; PAREDES, 1989), e o diazepam foi capaz de aumentar os reflexos de lordose, facilitando o comportamento sexual feminino (McCARTHY et al., 1995).

Portanto, sugere-se que o tratamento pré-natal com fipronil alterou a formação e/ou maturação do sistema GABAérgico da prole, além de interferir 
Discussões | 126

com os eixos HPA e HPG, sendo que essas alterações se manifestaram apenas nos testes comportamentais, sem alterar a formação física ou a anatomia dos órgãos observados nas necropsias. 


\section{Conclusones}

"É muito melhor lançar-se em busca de conquistas grandiosas, mesmo expondo-se ao fracasso, do que alinhar-se com os pobres de espírito, que nem gozam muito nem sofrem muito, porque vivem numa penumbra cinzenta, onde não conhecem nem vitoria, nem derrota"

(Theodore Roosevelt) 
O tratamento pré-natal com fipronil, do $6^{\circ}$ ao $20^{\circ}$ dia de gestação, causou leve toxicidade materna na dose de $10,0 \mathrm{mg} / \mathrm{Kg}$, apenas na segunda semana de gestação, porém, essa alteração não interferiu no desempenho reprodutivo maternal, nem causou alterações estruturais, ou de peso dos filhotes.

No comportamento maternal, as ratas que receberam 1,0 e 10,0 mg/Kg de fipronil cuidaram melhor de sua prole, recolhendo-os mais cedo e lambendo-os por mais tempo.

Os filhotes expostas a todas as doses desenvolveram os parâmetros físicos de forma igual aos filhotes controle, porém em parâmetros reflexológicos e comportamentais alterações foram observadas. De fato, os filhotes, machos e fêmeas, de ratas tratadas com a menor dose de fipronil, apresentaram atraso na expressão do reflexo de geotaxia negativa, reflexo este relacionado ao desenvolvimento motor controlado pelo sistema vestibular, por isso a avaliação do perfil locomotor em campo aberto, por sete dias consecutivos. Nesse sentido, constatou-se que o tratamento pré-natal com 0,1 e 1,0 mg/Kg foram capazes de interferir nos perfis da atividade geral desses filhotes, bem como foi capaz de causar aumento de ansiedade na idade adulta, detectado nas respostas em campo aberto, labirinto em cruz elevado e interação social.

Baseando-se nos resultados obtidos nesse estudo e nos dados da literatura, sugere-se que o fipronil administrado durante a gestação foi capaz de alterar o sistema GABAérgico da prole durante sua formação, interferindo com eixos endócrinos regulados por GABA, e essas alterações foram vistas apenas em parâmetros comportamentais, com o filhotes desenvolvendo-se fisicamente igual ao controle, mostrando assim, a importância desse estudo. 


\section{Referências}

"Talvez não tenha conseguido fazer o melhor, mas lutei para que o melhor fosse feito. Não sou tudo o que poderia ser, mas Graças a Deus, não sou o que era antes."

(Marthin Luther King) 
AGMO, A. PAREDES, R. GABAergic drugs and sexual behavior in the male rat. European Journal of Pharmacology. v. 112, p. 371-378, 1985.

AGMO, A.; SORIA, P.; PAREDES, R. GABAergic drugs and lordosis behavior in the female rat. Hormones and Behavior. v. 23, n. 3, p. 368-380, 1989.

AGMO, A. Male rar sexual behavior. Brain Research Protocols. v. 1, p. 203-209, 1997.

AKINGBEMI, B. T. et al. A Metabolite of Methoxychlor, 2,2-Bis(p-Hydroxyphenyl)-1,1,1Trichloroethane, Reduces Testosterone Biosynthesis in Rat Leydig Cells Through Suppression of Steady-State Messenger Ribonucleic Acid Levels of the Cholesterol SideChain Cleavage Enzyme. Biology of Reproduction. v. 62, p. 571-578, 2000.

ALTMAN, J.; SUDARSHAN, K. Postnatal development of locomotion in the laboratory rat. Animal Behaviour. v. 23, n. 4, p. 896-920, 1975.

ALVES, C. et al. Exposição ambiental a interferentes endócrinos com atividade estrogênica e sua associação com distúrbios puberais em crianças. Caderno de Saúde Pública. v. 23, n. 5, p. 1005-1014, 2007.

ANVISA - Agência Nacional de Vigilância Sanitária. Monografia de agrotóxicos: F43-Fipronil. Disponível pelo site: <http://portal.anvisa.gov.br/wps/wcm/connect/eba 05f80474594f39c9fdc3fbc4c6735/f43.pdf?MOD=AJPERES>. Acesso em: 10 jan. 2011.

ARCHER, J. Tests for emotionality in rats and mice: a review. Animal Behavior. v. 21, n. 2, p. 205-235, 1973.

BARROS, H.M.T. et al. The Effects of GABAergic Drugs on Grooming Behaviour in the Open Field. Pharmacology Toxicology. v. 74, n. 6, p. 339-344, 1994.

BEGEEL, S. et al. Sublethal toxicity of commercial insecticide formulations and their active ingredients to larval fathead minnow (Pimephales promelas). Science of the Total Environment. v. 408, p. 3169-3175, 2010. 
BERNARDI, M. M.; PALERMO-NETO, J. Effects of abrupt and gradual withdrawal from long-term haloperidol treatment on open field behavior of rats. Psychopharmacology. v. 65, n. 3, p. 247-250, 1979.

BERNARDI, M. M.; PALERMO-NETO, J. Dopamina e a função motora. Ciência e Cultura. v. 32, n. 7, p. 857-861, 1980.

BERNARDI, M. M.; DE SOUZA, H.; PALERMO-NETO, J. Effects of single and long-term haloperidol administration on open field behavior of rats. Psychopharmacology. v. 73, n. 2, p. 171-175, 1981.

BERNARDI, M. M. Exposição aos medicamentos durante o período perinatal. In: SPINOSA, H. S.; GÓRNIAK, S. L.; BERNARDI, M. M. Farmacologia Aplicada à Medicina Veterinária. 5.ed. Rio de Janeiro: Guanabara Koogan, 2011. p. 781-788.

BIANCO, B. et al. O papel dos desreguladores endócrinos na fisiopatologia da endometriose: revisão da literatura. Arquivos Brasileiros de Ciências e Saúde. v. 35, n. 2, p. 103-110, 2010.

BOBÉ, A. et al. Kinetics and Mechanisms of Abiotic Degradation of Fipronil (Hydrolysis and Photolysis). Journal of Agricultural and Food Chemistry. v. 46, p. 2834-2839, 1998.

CABONI, P.; SAMMELSON, R. E.; CASIDA, J. E. Phenylpyrazole Insecticide: Photochemistry, Metabolism, and GABAergic Action: Ethiprole compared with Fipronil. Journal of Agricultural and Food Chemistry. v. 51, p. 7055-7061, 2003.

CHEBIB, M. et al. (3-Aminocyclopentyl) methylphosphonic acids: novel $\mathrm{GABA}_{c}$ receptor antagonists. Neuropharmacology. v. 52, p. 779-787, 2007.

CONNELLY, P. Environmental fate of fipronil. In: Environmental Monitoring Branch. California Environmental Protection Agency. Dec. 2001. 17p. 
CORREIA, D. Avaliação da influência do padrão basal de ansiedade sobre o efeito ansiolítico e padrão de consumo de álcool num modelo de adição em camundongos. 2009. 131f. Tese (Mestre em Farmacologia) - Setor de Ciências Biológicas, Universidade Federal do Paraná, Curitiba. 2009.

COX, C. Fipronil. Journal of Pesticide Reform. v. 25, n. 1, p. 10-15, 2005.

CRUZ, A. de M. Modulação opíoidérgica na seleção comportamental após o parto. 2009. 77f. Tese (Mestre em Ciências) - Programa de Pós - graduação em Patologia Experimental e Comparada, Faculdade de Medicina Veterinária e Zootecnia, Universidade de São Paulo, São Paulo. 2009.

DALLEGRAVE, E. Toxicidade Reprodutiva do Herbicida Glifosato - Roundup ${ }^{\circledR}$ em Ratos Wistar. 2003. 200f. Tese (Doutorado em Ciências Veterinárias) - Programa de Pós-graduação em Farmacologia e Toxicologia, Universidade Federal do Rio Grande do Sul, Porto Alegre. 2003.

DASTON, G. P.; COOK, J. C.; KAVLOCK, R. J. Uncertainties for endocrine disrupters: our view on progress. Toxicological Sciences. v. 74, p. 245-252, 2003.

DAVIS, F. C.; GORSKI, R. A. Development of hamster circadian rhythms, I. Within-litter synchrony of mother and pup activity rhythms at weaning. Biology of Reproduction. $v$. 33, p. 353-362, 1985.

ENNACEUR, A.; MICHALIKOVA, S.; CHAZOT, P. L. Models of anxiety: Responses of rats to novelty in an open filed space and enclosed space. Behavioural Brain Research. v. 171 , p. 26-49, 2006.

EPA - ENVIRONMENTAL PROTECTION AGENCY. Guideline for Reproductive Toxicity Risk Assessment. EPA/630/R-96/009. Washington, DC, 1996.

ERDÕ, S. L.; VARGA, B.; HORVÁTH, E. Bicuculline-sensitive GABA receptor in rat ovary. European Journal of Pharmacology. v. 85, n. 2, p. 243-246, 1982. 
FAO/WHO - World Health Organization. Pesticide Residues in Food. Part I: Residues. Geneva: FAO and WHO, 2001. p. 191-367.

FAOUNDER, J. L. et al. Transfer assessment of fipronil residues from feed to cow milk. Talanta. v. 73, p. 710-717. 2007.

FILE, S. E.; HYDE, J. R. G. Can social interaction be used to measure anxiety?. British Journal of Pharmacology. v. 62, p. 12-24, 1978.

FILE, S. E.; POPE, J. H. Social interaction between drugged and undrugged rats. Animal Learning and Behavior. v. 2, p. 161-164, 1974.

FILE, S. E. The use of social interaction as a method for detecting anxiolytic activity of Chlordiazepoxide-like drugs. Review Article. Journal of Neuroscience Methods. v. 2, p. 219-238, 1980.

FONTENELE, E. G. P. et al. Contaminantes ambientais e os interferentes endócrinos. Arquivos Brasileiros de Endocrinologia e Metabolismo. v. 54, n. 1, p. 6-16, 2010.

GEIGERSEDER, C. et al. Stimulation of TM3 leygig cell proliferation via GABA(A) receptors: a new role for testicular GABA. Reproductive Biology and Endocrinology. v. 24, p. 2-13, 2004.

GERARDIN, D. C. C. et al. Sexual behavior, neuroendocrine, and neurochemical aspects in male rats exposed prenatally to stress. Physiology and Behabior. v. 84, p. 97-104, 2005.

GERIANNE, M. et al. Testosterone has rewarding affective properties in male rats: implications for the biological basis of sexual motivation. Behavioral Neuroscience. v. 108, n. 2 , p. 424-428, 1994. 
GHISI, N. C. Avaliação genotóxica em Rhamdia quelen após contaminação sub-crônica com fipronil. 2010. 89f. Tese (Mestrado em Ciências Biológicas) Programa de pós-graduação em genética, Universidade Federal do Paraná, Curitiba. 2010.

GHS - Global Harmonization System of Classification and Labeling of Chemicals (GHS). Published by UNECE - United Nations Economic Commission for Europe. June, 2011.

GÓRNIAK, S. L.; SPINOSA, H. S. e BERNARDI, M. M. Toxicologia do desenvolvimento. In: SPINOSA, H. S.; GÓRNIAK, S. L.; PALERMO-NETO, J. Toxicologia aplicada à Medicina Veterinária. Barueri: Manole, 2008. p. 701-731.

GUIMARÃES, R. M.; ASMUS, C. I. R. F. Desreguladores endócrinos e efeitos reprodutores em adolescentes. Caderno de Saúde Coletiva. V.18, n. 2, p. 203-208. 2010.

GUNASEKARA, A. S.; TROUNG, T. Environmental Fate of Fipronil. In: California Environmental Protection Agency. Environmental Monitoring Branch. 2007. 28.p.

GUNASEKARA, A. S. et al. Environmental fate and toxicology of fipronil. Journal of Pesticide Science. v. 32, n. 3, p.189-199, DOI: 10.1584/jpestics.R07-02, 2007.

GUPTA, R. C. Fipronil In.: Veterinary Toxicology: Basic and Clinical principles. New York: Elsevier. p. 502-505. 2007.

HAINZL, D; COLE, L. M.; CASIDA, J. E. Mechanisms for Selective Toxicity of Fipronil Insecticide and Its Sulfone Metabolite and Desulfinyl Photoproduct. Chemical Research in Toxicology. v. 11, p. 1529-1535, 1998.

HASSANI, A. K. E. et al. Glutamatergic and GABAergic effects of fipronil on olfactory learning and memory in the honeybee. Invertebrate neuroscience. v. 9, p. 91-100, 2009. 
IKEDA, T. et al. Fipronil modulation of $\mathrm{GABA}_{\mathrm{A}}$ receptor single-channel currents. Pest Management Science. v. 60, p. 487-492, DOI: 10.1002/ps.830, 2004.

ILO - INTERNATIONAL LABOUR ORGANIZATION. Final Draft for GHS web. Chapter 11: Reproductive Toxicity. Disponível no site da organização: <http://www.ilo.org/legacy/english/protection/safework/ghs/ghsfinal/ghsc11.pdf>. Acesso em: 7 mai. 2012.

IPCS/INCHEM - International Programme on Chemical Safety. Fipronil. Pesticide Residues in Food - 1997. Disponível em: <http://www.inchem.org >. Acesso em: 22 de abr. 2012.

ISLAM, R.; LYNCH, J. Mechanism of action of the insecticides, lindane and fipronil, on glycine receptor chloride channels. British Journal of Pharmacology. v. 165, p. 2707-2720, 2012.

JACKSON, D. et al. Fipronil. Technical Fact Sheet. National Pesticide Information Center, Oregon State University Extension Services. Updated in 2009. Disponível no site da organização: <http://npic.orst.edu/factsheets/fiptech.pdf>. Acesso em: 10 jan. 2011.

JANSSEN, D. et al. Dorsal Unpaired Median Neurons of Locusta migratoria express ivermectin- and fipronil-sensitive glutamate-gate chloride channels. Journal of Neurophysiology. v.97, p. 2642-2650, 2007.

JONES, D. L.; MOGENSON, G. J.; WU, M. Injections of dopaminergic, cholinergic, serotoninergic and gabaergic drugs into the nucleus accumbens: effects on locomotor activity in the rat. Neuropharmacology. v. 20, p. 29-37, 1980.

KOIFMAN, S.; KOIFMAN, R. J.; MEYER, A. Human reproductive system disturbances and pesticide exposure in Brazil. Caderno de Saúde Pública. v. 18, n. 2, p. 435-445, 2002. 
LAL, H.; EMMETT-OGLESBY, M.W. Behavioral analogues of anxiety. Animal models.

Neuropharmacology. v. 22, n. 12, parte B, p. 1423-41, 1983.

LEE, G; GAMMIE, S. C. GABA receptor signaling in caudal periaquedutal gray regulates maternal aggreesion and maternal care in mice. Behavioural Brain Research. v. 213, p. 230-237, 2010.

LEMINI, C.; CANCHOLA, E. Induction of sexual behavior in female rats by the $17 \beta-$ aminoestrogens prolame, butolame and pentolame. Proceeding of the Western Pharmacology Society. v. 52, p. 39-42, 2009.

LEVINE, S. Primary social relationships influence the development of the hypothalamicpituitary-adrenal axis in the rat. Physiology and Behavior. v. 73, p. 255-260, 2001.

LINCK, V. M. Perfil antipsicótico de alstonina: ação em modelos de sintomas negativos, alterações em aminas biogênicas e efeitos adversos em camundongos. 2008. 89f. Tese (Mestre em Ciências Farmacêuticas) - Universidade Federal do Rio Grande do Sul, Porto Alegre. 2008.

LISTER, R. Ehologically-based animal models of anxiety disorders. Pharmacology and Therapeutics. v. 46, p. 321-340, 1990.

MACLUSKY, N.; NAFTOLIN, F. Sexual differentiation of the central nervous system. Science. v. 211, p. 1294-1303, 1981.

McCARTHY, M. M. et al. Infusions of Diazepam and Allopregnanolone into the Midbrain Central Gray Facilitate Open-Field Behavior and Sexual Receptivity in Female Rats. Hormones and Behavior. v. 29, n. 3, p. 279-295, 1995.

MCLACHLAN, J. A. Environmental signaling: What embryos and evolution teach us about endocrine disrupting chemicals. Endocrine Reviews. v. 22, n. 3, p. 319-341, 2001. 
MANI, S. Ligand-independent activation of progestin receptors in sexual receptivity. Hormones and Behaviour. v. 40, p. 183-190, 2001.

MARCONDES, F. K.; BIANCHI, F. J; TANNO, A. P. Determination of the estrous cycle phases of rats: some helpful considerations. Brazilian Journal of Biology. v. 64, $n$. 4, parte A, p. 609-614, 2002.

MARTINS, A. P. Efeitos neurocomportamentais do fipronil administrado em dose única a ratos. 2009. 86f. Tese (Mestrado em Ciências) - Programa de Patologia Experimental e Comparada, Faculdade de Medicina Veterinária e Zootecnia, Universidade de São Paulo, São Paulo. 2009.

MASUTTI, C. S. M.; MERMUT, A. R. Degradation of fipronil under laboratory conditions in a tropical soil from Sirinhaém Pernambuco, Brazil. Journal of Environmental Science and Health. v. 42, parte B, p. 33-43, 2007.

MELLO, M.S.C. Avaliação da Toxicidade Reprodutiva do Pesticida Trifenil Hidróxido de Estanho (TPTH) em Camundongos. 2007. 154f. Tese (Doutorado em Vigilância Sanitária) - Instituto Nacional de Controle de Qualidade em Saúde, Fundação Oswaldo Cruz, Rio de Janeiro. 2007.

MOHAMED, F. et al. Acute human self-poisoning with the $N$-phenylpyrazole insecticide fipronil - a $G_{A B A}$ - gated chloride channel blocker. Journal of Toxicology Clinical Toxicology. v. 42, n. 7, p. 955-963, 2004.

MORATO, S. O papel da visão na aversão aos espaços abertos no labirinto em cruz elevado. Psicologia USP. v. 17, n. 4, p. 159-174, 2006.

MORICEAU, S.; SULLIVAN, R. M. Maternal presence serves as a switch between learning fear and attraction in infancy. Nature Neuroscience. v. 9, n. 8, p. 10041006, 2006. 
MOTTA, S. et al. Lobeira powder administration during rat lactation: Maternal behavior and neuromotor development of pups. Revista Brasileira de Zootecnias. Juiz de Fora. v. 4, n. 2, p. 255-268, 2002.

MOURA, L. M. et al. Morphine infusions into the rostrolateral periaquedutal gray affect maternal behaviors. Brazilian Journal of Medical and Biological Research. v. 43, p. 899-905, 2010.

MURILLO, L. et al. Inhibition of protein kinase C decreases sensitivity of GABA receptor subtype to fipronil insecticide in insect neurosecretory cells. Neurotoxicology. v. 32, p. 828-835, 2011.

NARAHASHI, T. et al. Differential actions of insecticides on target sites: basis for selective toxicity. Human and Experimental Toxicology. v. 26, p. 361-366, 2007.

NARAHASHI, T. et al. T. Glutamate-activated chloride channels: Unique fipronil targets present in insects but not in mammals. Pesticide Biochemistry and Physiology, 2009. DOI:10.1016/j.pestbp.2009.07.008

OECD - Organization for Economic Co-operation and Development. Monograph Series on Testing and Assessment $\mathbf{n}^{\circ} \mathbf{1 7}, 1999$.

OHI, M. et al. Reproductive adverse effects of fipronil in Wistar rats. Toxicology Letters. v.146, p. 121-127. 2004.

PEIXOTO, A. S.; COELHO, M. C. O. C; BARBOSA, M. B. Atualidades em tratamentos utilizdos em dermopatias de cães - Revisão. Revista de Educação Continuada do Conselho Regional de Medicina Veterinária de São Paulo. v. 5, fascículo 1, p. 14 - 24. 2002.

PFAFF, D. W. et al. Cellular and molecular mechanisms of female reproductive behaviors. In: KNOBIL, E. et al. Physiology of Reproduction. 2.ed. NY: Raven Press, p. 107-220, 1994. 
PFAFF, D. W. et al. Reverse engineering the lordosis behavior circuit. Hormones and Behavior. v. 54, n. 3, p. 347-354, 2008.

PINTO e SILVA, P. V. M. Efeitos combinados de desreguladores endócrinos em Daphnia magna. 2011. 53p. Tese (Mestrado em Biologia Molecular e Celular) Departamento de biologia da Universidade de Aveiro, Aveiro - Portugal. 2011.

QURESHI, G. A.; SÖDERSTEN, P. Sexual activity alters the concentration of amino acids in the cerebrospinal fluid of male rats. Neuroscience Letters. v. 70, p. 374378, 1986.

RANG, H. P. et al. Aminoácidos transmissores. In: Farmacologia. Rio de Janeiro: Elsevier, 2004. p. 527-540.

RAVETON, M. et al. Soil distribution of fipronil and its metabolites originating from a seed-coated formulation. Chemosphere. v. 69, p. 1124-1129, 2007.

RHÔNE-POULENC. Atelier International Fipronil/lutte antiacridienne. Lyon: RhônePoulenc Agrochimie, 1995.

RIECKE, K.; STAHLMANN, R. Test systems to identify reproductive toxicants. Revista Internacional de Andrología. Elsevier. v. 32, p. 209-218, 2000.

RODGERS, R. J.; DALVI, A. Anxiety, defense and the elevated plus-maze. Neuroscience and Biobehabioral Reviews. v. 21, n. 6, p. 801-810, 1997.

RODGERS, R. J. et al. Animal models of anxiety: an ethological perspective. Brazilian Journal of Medical and Biological Research. v. 30, p. 289-304, 1997.

RODRIGUES-ALVES, P. S. B. et al. Moxidectin interference on sexual behavior, penile erection and hypothalamic GABA levels of male rats. Research in Veterinary Science. v. 84, p. 100-106, 2008. 
RODRIGUES-ALVES, P. S. B. et al. Moxidectin interference on motor activity of rats. Brazilian Archives of Biology and Technology. v. 52, n. 4, p. 883-391, 2009.

ROMANO, R. M.; ROMANO, M. A.; OLIVEIRA, C. A. Glifosato como desregulador endócrino químico. Ambiência - Revista do Setor de Ciências Agrárias e Ambientais. v. 5, n. 2, p. 359-372, 2009.

SALE A. et al. Maternal enrichment during pregnancy accelerates retinal development of the fetus. PLoS ONE. v.2, n.11, e1160, 2007. DOI:10.1371/journal.pone.0001160

SALGADO, J. V.; HETEM, L. A.; SANDNER, G. Modelos experimentais de esquizofrenia - uma revisão. Revista Brasileira de Psiquiatria. v. 28, n. 2, p. 135-141, 2006.

SALVIANO, M. F. Efeitos comportamentais da Ipsapirona em ratos selecionados para altos e baixos índices de congelamento condicionado. 2008. 88f. Tese (Mestrado em Biologia Animal) - Instituto de Biologia, Universidade de Brasília, Brasília. 2008.

SANTAMARTA, J. A ameaça dos disruptores endócrinos. Agroecologia.e Desenvolvimento Rural Sustentável.v.2, n.3, p. 18-29, 2001.

SILVA, M. R. P. et al. Is perinatal picrotoxin anxiogenic? Brazilian Journal of Medical and Biological Research. v. 28, n. 6, p. 663-666, 1995.

SILVA, M. R. P. et al. Perinatal treatment with picrotoxin induce sexual, behavioral, and neuroendocrine changes in male rats. Pharmacology Biochemistry and Behavior. v. 60 , n. 1, p. 203-208, 1998.

SILVA, A. S. Efeitos neurocomportamentais da exposição prolongada de ratos ao fipronil. 2008. 108f. Tese (Mestrado em Ciências) - Programa de pós-graduação em Toxicologia e Análises Toxicologicas, Faculdade de Ciências Farmacêuticas, Universidade de São Paulo, São Paulo. 2008. 
SILVA, V.C.L. da. Avaliação da Toxicidade Reprodutiva de Ratas Wistar Submetidas à Ingestão do Extrato Etanólico das Folhas de NIM (Azadirachta indica A. Juss). 2010. 51f. Tese (Mestrado em Ciências Veterinárias) - Programa de Pós-graduação em Ciências Veterinárias, Universidade Federal Rural de Pernambuco, Recife. 2010.

SGP-CECBP - Meeting of Scientific Guidance Panel of the California Environmental Contaminant Biomonitoring Program. Fipronil [CASRN: 120068-37-3]. July 28-29, California, 2009.

SIMERLY, R. B. Anatomical Substrates of Hypothalamic Integration. In: PAXINOS, G. (editor). The Rat Nervous System. $3^{\text {rd }}$ ed. Sydney, Australia: Academic Press, 2004. 335-368 p.

SOBRIAN, S. K. Aversive prenatal stimulation: effects on behavioral, biochemical, and somatic ontogeny in the rat. Developmental Psychobiology. v.10, p.41-51, 1977.

SOLOMON, G.; SCHETTLER, T. Endocrine Disruption and Potential Human Health Implications. Canadian Medical Association Journal, v. 163, p.1471-1476, 2000.

SOUSA, F. C. F. et al. Plantas medicinais e seus constituintes bioativos: Uma revisão da bioatividade e potenciais benefícios nos distúrbios da ansiedade em modelos animais. Revista Brasileira de Farmacognosia. v. 18, p. 642-654, 2008.

SPYKER, J. M. Assessing the impact of low level chemicals on development: behavioral and latent effects. Federation Proceedings. v. 39, p. 141-145, 1987.

STARK, J. D., VARGAS, R. I. Toxicity and hazard assessment of fipronil to Daphnia pulex. Ecotoxicology and Environmental Safety. v. 62, p. 11-16, 2005.

STEELE, M. S.; BENNETT, R. A. Clinical Technique: Dorsal ovariectomy in rodents. Journal of Exotic Pet Medicine. v. 20, n. 3, p. 222-226, 2011. 
STEHR, M. C. et al. The developmental neurotoxicity of fipronil: Nitichord degeneration and locomotor defects in zebrafish embryos and larvae. Toxicological Sciences. v. 92, n. 1, p. 270-278, 2006.

SZEGEDI, V. et al. Transient alterations in neuronal and behavioral activity following bensultap and fipronil treatment in rats. Toxicology. v. 214, p.67-76, 2005.

TEGNÉR J. et al. The spinal GABA system modulates burst frequency and intersegmental coordination in the lamprey: differential effects of $G A B A_{A}$ and $G A B A_{B}$ receptors. Journal of Neurophysiology. v. 69, p. 647-657, 1993.

TERÇARIOL, P. R. G. Avaliação neurocomportamental de ratos expostos agudamente ao fipronil - Influência de Diazepam e Flumazenil. 2007. 78f. Tese (Mestrado em Ciência Veterinária) - Faculdade de Medicina Veterinária e Zootecnia, Universidade Estadual Paulista Julio de Mesquita Filho, UNESP, Botucatu. 2007.

TINGLE, C.C.D. et al. Health and environmental effects of fipronil. Briefing paper. Pesticide Action Network UK. P. 1-30. 2000.

TINGLE, C. C. D. et al. (2003) Fipronil: environmental fate, ecotoxicology and human health concerns. Reviews of Environmental Contamination and Toxicology. v. 176, p. 1-66, 2003.

USEPA - United States Environmental Protection Agency. Fipronil Memorandum. Washington, D.C. April, 1996.

USEPA - United States Environmental Protection Agency. Environmental fate of fipronil. Washington: U.S.EPA Office of Prevention Pesticides and Toxic Substances, 2001. 17p. Disponível em: <http://www.pw.ucr.edu/textfiles/fipronil.pdf>. Acesso em: 14 fev. 2011.

VIEIRA, M. L. Comportamento materno e paterno em roedores. Biotemas. v. 16, n. 2, p. 159-180, 2003. 
WALSH, R. N.; CUMMINS, R. A. The open-field test: a critical review. Psychological Bulletin. v. 83, n. 3, p. 482-504, 1976.

WANG, C. Y. et al. Differential alterations of GABAA receptor ( $a 1, \beta 2, Y 2$ subunit) expression and increased seizure susceptibility in rat offspring from morphine-addicted mothers: Beneficial effect of dextromethorphan. Neuroscience Letters. v. 489, p. 59, 2011.

WEAVER, I. C. G. et al. Epigenetic programming by maternal behavior. Nature Neuroscience. v. 7, n. 8, p. $847-854,2004$.

ZANATTA, A. P. Efeito estimulatório da tiroxina no transporte de aminoácidos, captação de ${ }^{45} \mathrm{Ca}^{2+}$ e na exocitose em células de sertoli de testículos de ratos imaturos. 2011. 104f. Tese (Mestre em Bioquímica) - Programa de Pós-graduação em Bioquímica da Universidade Federal de Santa Catarina, Florianópolis. 2011.

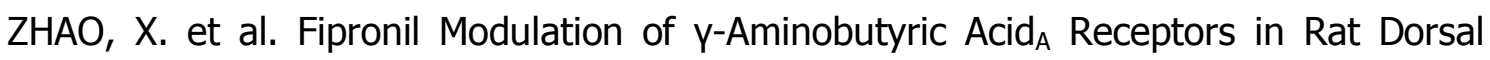
Root Ganglion Neurons. Journal of Pharmacology and Experimental Therapeutics. v. 296, n. 3, p. $914-921.2000$.

ZHAO, X. et al. Differential action of fipronil and dieldrin insecticides on GABA-gated chloride channels in cockroach neurons. Journal of Pharmacology and experimental therapeutics. v. 306, n. 3, p. 914-924, 2003.

ZHAO, X. et al. Fipronil Is a Potent Open Channel Blocker of Glutamate- Activated Chloride Channels in Cockroach Neurons. Journal of Pharmacology and Experimental Therapeutics. v. 310, n. 1, p. $192-201.2004$.

ZHAO, X. et al. Sulfone Metabolite of Fipronil Blocks $\mathrm{Y}$-Aminobutyric Acid- and Glutamate-Activated Chloride Channels in Mammalian and Insect Neurons. Journal of Pharmacology and Experimental Therapeutics. v. 314, n. 1, p. 363 - 373. 2005.

ZHU, G. et al. Microbial degradation of fipronil in clay loam soils. Water Air Soil Pollution. v. 153, p. 35-44, 2004. 